\title{
Vasomotion and skeletal muscle perfusion
}

Citation for published version (APA):

Oude Vrielink, H. H. E. (1988). Vasomotion and skeletal muscle perfusion. [Doctoral Thesis, Maastricht University]. Rijksuniversiteit Limburg. https://doi.org/10.26481/dis.19881202ho

Document status and date:

Published: 01/01/1988

DOI:

10.26481/dis.19881202ho

Document Version:

Publisher's PDF, also known as Version of record

\section{Please check the document version of this publication:}

- A submitted manuscript is the version of the article upon submission and before peer-review. There can be important differences between the submitted version and the official published version of record.

People interested in the research are advised to contact the author for the final version of the publication, or visit the DOI to the publisher's website.

- The final author version and the galley proof are versions of the publication after peer review.

- The final published version features the final layout of the paper including the volume, issue and page numbers.

Link to publication

\footnotetext{
General rights rights.

- You may freely distribute the URL identifying the publication in the public portal. please follow below link for the End User Agreement:

www.umlib.nl/taverne-license

Take down policy

If you believe that this document breaches copyright please contact us at:

repository@maastrichtuniversity.nl

providing details and we will investigate your claim.
}

Copyright and moral rights for the publications made accessible in the public portal are retained by the authors and/or other copyright owners and it is a condition of accessing publications that users recognise and abide by the legal requirements associated with these

- Users may download and print one copy of any publication from the public portal for the purpose of private study or research.

- You may not further distribute the material or use it for any profit-making activity or commercial gain

If the publication is distributed under the terms of Article $25 \mathrm{fa}$ of the Dutch Copyright Act, indicated by the "Taverne" license above, 
Vasomotion and skeletal muscle perfusion 
III

krîps repme meppoi 


\title{
Vasomotion and skeletal muscle perfusion
}

\section{Proefschrift}

ter verkrijging van de graad van doctor aan de Rijksuniversiteit Limburg te Maastricht, op gezag van de Rector Magnificus, Prof. Dr. F.I.M. Bonke, volgens het besluit van het College van Dekanen, in het openbaar te verdedigen op vrijdag, 2 december 1988 om 14.00 uur

\author{
door
}

Hubertus Hermanus Egbert Oude Vrielink geboren te Almelo in 1958. 
Promotor:

Prof. Dr. R.S. Reneman

Co-promotores: $\quad$ Dr. D.W. Slaaf

Dr. G.J. Tangelder

Beoordelingscommissie: Prof. Dr. H.A.J. Struyker Boudier

Prof. Dr. P. Gaehtgens

Prof. Dr. N. Westerhof

Prof. Dr. F. ten Hoor

Dr. M.J.H.M. Jacobs

Het verschijnen van dit proefschrift werd mede mogelijk gemaakt door steun van de Nederlandse Hartstichting.

Dit onderzoek werd gesubsidieerd door de Stichting voor Medisch Onderzoek en Gezondheidsonderzoek MEDIGON (subsidienummer: 900-517-157). 
es kann auch anders, aber so geht es auch.

(Wageningen, Prof. H.C.D. de Wit)

voor mijn ouders

aan de 116 konijnen die bij dit onderzoek hum leven lieten 


\section{TABLE OF CONTENTS}

1. General introduction 1

2. Blood flow in skeletal muscle 5

2.1 Structure of the skeletal muscle vascular bed 5

$2.2 \quad$ Local regulation of blood flow 8

2.3 Vasomotion: dynamic behavior of arterioles 10

3. Materials and methods 15

4. Does capillary recruitment exist in young rabbit skeletal muscle? 19

$\begin{array}{lll}4.1 & 19\end{array}$

4.2 Materials and methods 20

$\begin{array}{lll}4.3 & \text { Results } & 23\end{array}$

4.4 Discussion $\quad 25$

$\begin{array}{lll}4.5 & \text { Summary } & 27\end{array}$

5. Effective diameter as a determinant of local vascular resistance

in the presence of vasomotion $\quad 29$

$\begin{array}{lll}5.1 & \text { Introduction } & 29\end{array}$

$5.2 \quad$ Methods 30

5.3 Results and discussion 33

5.4 Summary $\quad 36$

5.5 Appendix $\quad 37$

6. Changes in vasomotion pattern and local arteriolar resistance
during stepwise pressure reduction

6.1 Introduction 39

6.2. Materials and methods 40

6.3 Results 43

6.4 Discussion 50

6.5 Summary $\quad 52$

6.6 Appendix 53

7. Analysis of vasomotion waveform changes during pressure

$7.1 \quad$ Introduction $\quad 55$

$7.2 \quad$ Materials and methods $\$ 6$

$\begin{array}{lll}7.3 & \text { Results } & 61\end{array}$

7.4 Discussion 68

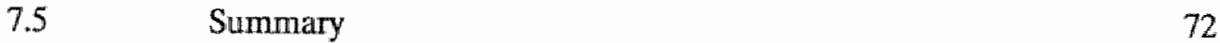

8. General discussion 73

9. References 83

10. Summary 85

11. Samenvatting $\quad 89$

$\begin{array}{lr}\text { Curriculum vitae } & 102\end{array}$

$\begin{array}{ll}\text { Publicaties } & 103\end{array}$

$\begin{array}{ll}\text { Nawoord } & 104\end{array}$ 


\section{GENERAL INTRODUCTION}

In skeletal muscle, small arterioles play an important role in blood flow regulation. For example, dilation of these arterioles is responsible for the increase in blood flow to the tissue during enhanced metabolic activity, as during excercise. Also in case of reduced perfusion pressure arterioles dilate to maintain the blood flow at sufficiently high levels, a phenomenon known as autoregulation. Dilation of arterioles is controlled by such factors as transmural pressure (Grände and Mellander, 1978; Johnson, 1980; Borgström et al., 1984), oxygen (Klabunde and Johnson, 1977 ${ }^{\mathrm{b}}$; Lindbom et al., 1980; Pittman, 1981), adenosine (Klabunde, 1983; Burnstock, 1987), potassium, lactate and inorganic phosphate (Hudlická and Khelly, 1985).

In the past data on blood flow regulation were gathered in whole organ studies. In more recent years, however, these studies are more and more directed towards the microcirculatory level. One of the major problems encountered in the interpretation of the data obtained in microcirculatory studies is their enormous variability. For instance, capillary flow velocity may vary largely from area to area or even in adjacent capillaries (Eriksson and Myrhage, 1972; Kayar and Banchero, 1985; Lindbom and Arfors, 1985), a phenomenon generally described as spatial heterogeneity. In addition, perfusion patterns of individual capillaries may fluctuate in time (Klabunde and Johnson, 1977 ${ }^{\mathrm{a}}$; Johnson, 1980; Lindbom et al., 1980; Renkin et al., 1981), a phenomenon known as temporal heterogeneity. Because flow heterogeneity has been insufficiently taken into account, attempts to compare microcirculatory data with whole organ data failed to reconcile total flow with the sum of capillary flows (Intaglietta, 1981; Duling, 1982; Honig and Gayeski, 1982; Hudlické et al., 1982; Damon and Duling, 1984). The origin of spatial flow heterogeneity is diverse. It depends on passive, geometrical factors, such as diameter and length of the capillaries (Damon and Duling, 1985; Dawant et al., 1986), but is also influenced by rheological factors (Vicaut et al., 1987). A third factor which might play a role is the presence of permanently non-perfused capillaries in the muscle at rest. The existence of the latter phenomenon has been subject to argument for many years. According to some investigators, part of the capillaries is not perfused during 
resting conditions and will be additionally perfused in situations of increased flow demand, a phenomenon generally called capillary recruitment (Honig et al., 1980; Lindbom et al., 1982; McDonagh et al., 1982; Prewitt et al., 1982). In other studies, however, the majority of the functionally available skeletal muscle capillaries was found to be perfused already at rest (Klabunde and Johnson, 1977 ${ }^{\mathrm{a}}$; Hudlická et al., 1982; Damon and Duling, 1985), although the rate of perfusion in some capillaries appeared to be very low (Tyml, 1986).

Temporal heterogeneity in capillary perfusion most likely results from diameter variations in upstream arterioles. Since precapillary sphincters are probably not present in skeletal muscle (Eriksson and Myrhage, 1972; Eriksson and Lisander, 1972) and slowly perfused capillaries were found in clusters (Renkin et al., 1981), indicating a common control of the perfusion of groups of capillaries, terminal arterioles are the most likely origin of temporal heterogeneity. The observation of Renkin and colleagues (1981) is supported by direct intravital microscopic observations in skeletal muscle showing that flow fluctuates synchronously in groups of capillaries. This flow pattern is associated with rhythmic variations in diameter of the feeding arterioles, a phenomenon known as vasomotion (Lindbom et al., 1980; Tangelder et al., 1984; Lund et al., 1987; Slaaf et al., 1987\%, Wiederhielm and Slaaf, 1987). Closure of the lumen of a terminal arteriole results in a complete stand-still of the red blood cells in all downstream capillaries. These findings indicate that vasomotion plays an important role in the heterogeneity of capillary flow. The pattern of vasomotion changes during reduction of arterial pressure (Bouskela and Wiederhielm, 1979; Johnson, 1980; Burrows and Johnson, 1983). The consequences of the presence of vasomotion for tissue perfusion and the relation between the changes in vasomotion pattern and local skeletal muscle blood flow control are still incompletely understood.

The aims of the present study were to gather insight into the phenomenon of vasomotion at different levels in the arteriolar bed, and to investigate the relation between vasomotion and skeletal muscle blood flow regulation. More specifically, we investigated:

1. whether in a resting skeletal muscle preparation showing vasomotion all or only part of the functionally available microvessels are involved in distributing blood over the tissue, i.e. whether recruitment exists (chapter 4),

2. the consequences of the presence of vasomotion for local arteriolar resistance (chapter 5),

3. the changes in vasomotion pattern at different arteriolar levels during arterial pressure reduction, and their relation to muscle perfusion parameters (chapter 6),

4. the changes in vasomotion waveform during different interventions, to obtain insight into the mechanisms of vasomotion control (chapter 7).

The studies were performed on the rabbit tenuissimus muscle in situ. This muscle is readily accessible for intravital microscopic observation without interference with its normal resting state, or nerve and blood supply (Rutili and Arfors, 1976; Lindbom et al., 1977; Reneman et al., 1980). 
The thesis is preceeded by a general introduction. In chapter 2 a brief survey is given of the anatomy and physiology of skeletal muscle relevant to the present investigations, while the methods as used in the various studies are summarized in chapter 3 . The thesis is concluded with a general discussion (chapter 8). 


\section{BLOOD FLOW IN SKELETAL MUSCLE}

In this chapter an overview is given of recent and for the present thesis most relevant information. Special attention is paid to the phenomenon of vasomotion. For more general information in the field of skeletal muscle blood flow regulation the reader is referred to surveys by Granger and co-workers (1984), Granger and Shepherd (1979), Johnson $(1978,1980)$ and Renkin (1984).

\subsection{Structure of the skeletal musclle vascular bed}

Most skeletal muscles commonly used for intravital microscopic studies are supplied by more than one feeding artery (spinotrapezius muscle: Engelson et al., 1986; sartorius muscle: Burton, 1973; Koller et al., 1987; gracilis muscle: Swain and Lalone, 1982). After entrance of the muscle, through the epimysium, these arteries feed an arcading network within the muscle (Sullivan and Pittman, 1982; Engelson et al., $1985^{\text {b }}$; Ellsworth et al., 1987). These multiple inputs ensure that failure of one of the feeding arteries remains without dramatic consequences for muscle blood supply. The arcading system is responsible for the distribution of blood over the main areas of the muscle and provides rellatively stable hemodynamics (Greene et al., 1988). From the arcading system, transversely branching vessels are responsible for the blood supply of sharply defined areas of the muscle (Myrhage and Eriksson, 1984; Engelson et al., 1985 ${ }^{b}$ ). These areas are called 'vascular units' (Eriksson and Myrhage, 1972) and no major vascular interconnections with adjacent units exist (Koller et al., 1987). Within a vascular unit, large arterioles frequently form a second arcading network (Lindbom and Arfors, 1984). Because the tenuissimus muscle, as used in this thesis, is considered to be representative of a vascular unit (Eriksson and Myrhage, 1972; Amundson et al., 1980), a description of its vascular bed is presented as a representative model.

In the tenuissimus muscle, a thin airfoil-shaped muscle in the hind limb of cats and rab- 


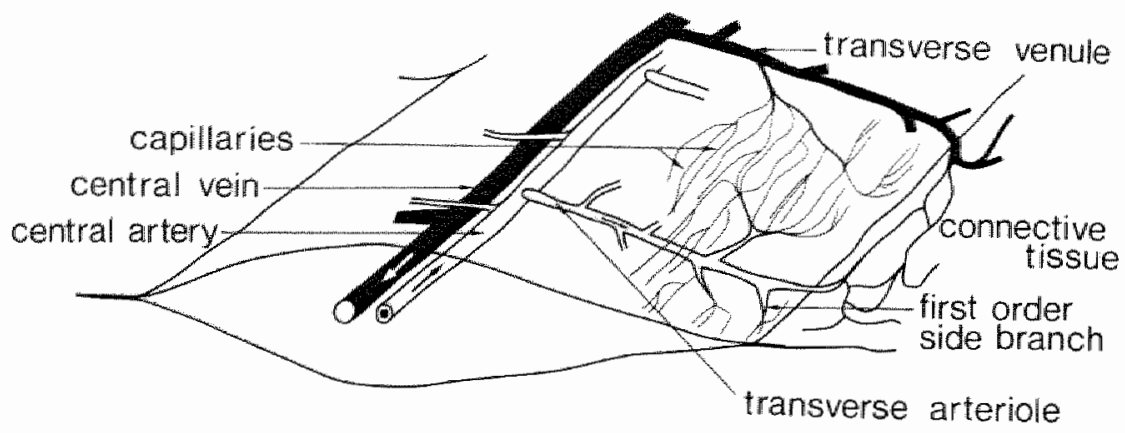

FIGURE 2. I : Schematic crosis-sectional wew of the rabbit tenuissimus muscle and its vascular bed. The arrows in the vesseis indicate the direction of flow.

bits, a central artery and vein run parallel to the muscle fibers in its thickest part (figure 2.1). From the central artery, blood is distributed over the muscle by branches that run perpendicularly or obliquely to the muscle fibers. These branches and their major dichotomies are called transverse arterioles, the resting mean diameter of which may vary between 6 and $45 \mu \mathrm{m}$ (Lindbom and Arfors, 1984; Tangelder et al., 1984; Meyer et al., $1987^{\mathrm{a}}$; Slaaf et $a l ., 1987^{\mathrm{a}}$ ). Transverse arterioles frequently form arteriolar arcades (Lindbom and Arfors, 1984) and mostly end in the fascia near the muscle where they form short shunt-like connections with draining venules (Lindbom, 1986). From the transverse arterioles, a number of small vessels branch off, which divide several times before ending in the capillaries. An illustration of a transverse arteriole and its first order side branches is given in figure 2.2. The first order side branches may range in diameter from 4 to $12 \mu \mathrm{m}$ (Tangelder et al., 1984; Meyer et al., 1987 $7^{\mathrm{a}}$ ) and are considered to be functionally the terminal arterioles since they control the perfusion of the capillaries (Tangelder et al., 1984). More than 50 capillaries (Lindbom and Arfors, 1985), about $5 \mu \mathrm{m}$ in diameter and $1000 \mu \mathrm{m}$ long (Eriksson and Myrhage, 1972; Myrhage and Hudlická, 1978), may branch from one functional terminal arteriole. An illustration of the capillary bed in the rabbit tenuissimus muscle is presented in figure 2.3 .

The whole muscle consists of several repeating modules, each containing a transverse arteriole with its side branches, capillaries, collecting venules and one or more transverse venules. The venous system is comparable to the arteriolar network described above (Engelson et al., 1985 ${ }^{\mathrm{a}}$ ).

The division of the muscle into vascular units seems to hold for skeletal muscle in general (Eriksson and Myrhage, 1972). Also the arrangement in repeating modules within a vascular unit is a common observation (Skalak and Schmid-Schönbein, 1986;

FIGURE 2:2: Drawing of a transverse atteriole, nunning from the central artery to the connective tissue, its first order side branches, wo of which are indicated by asterisks, and some of their downstream capillaries. The arrow indicates the direction of flow. The dashed parts of the transwerse arteriole were not in focus. 


\section{central artery}

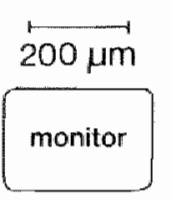

\section{transverse}

arteriole

muscle fiber direction

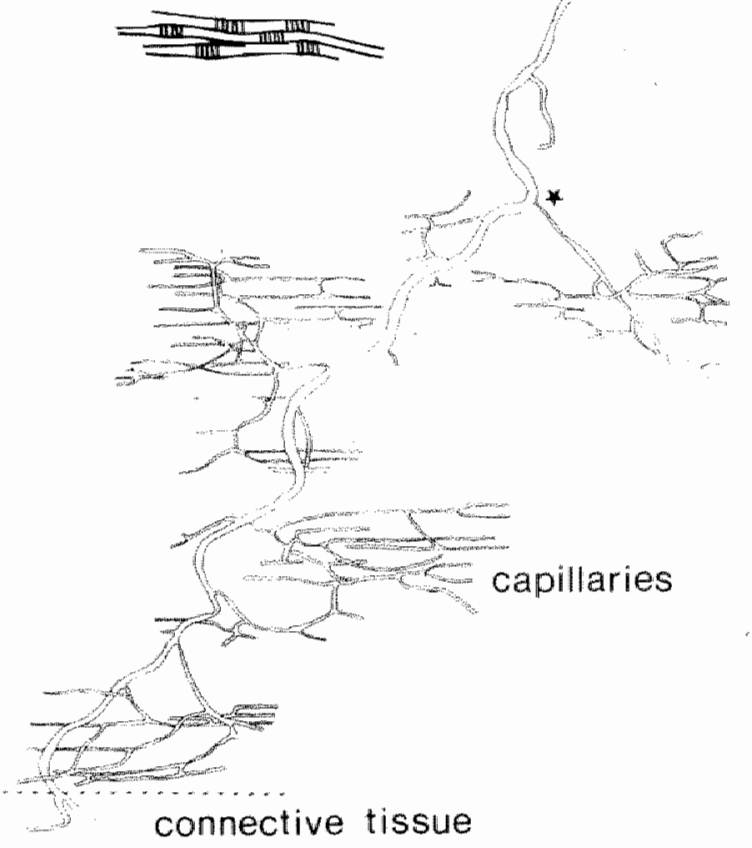




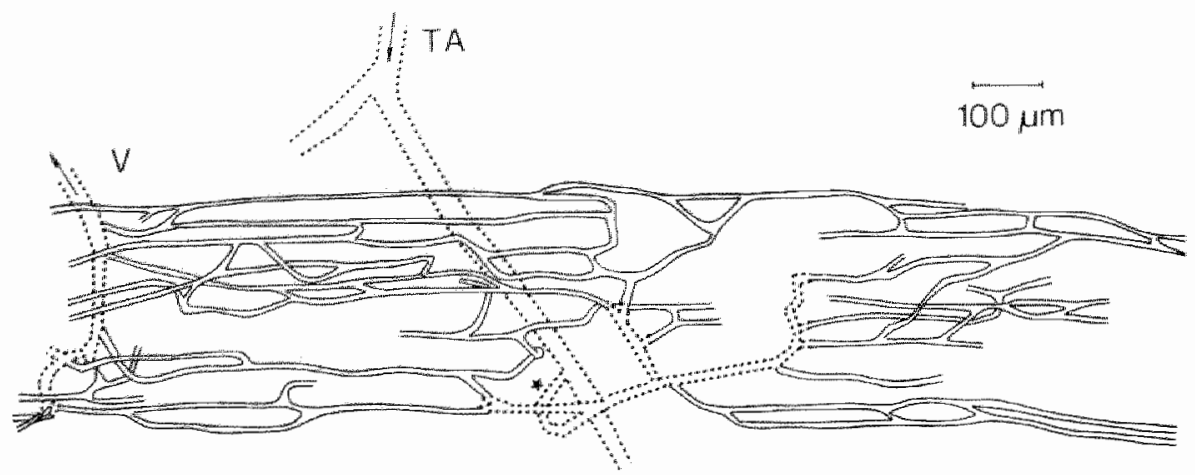

FIGURE 2.3: Drawing of a capillary bed in the rabbit terutssimus muscle. The bed is fed by a first order side branch (indicated by an asterisky of the transwerse arteriole (TA) and drained by venules, one of which is shown at left (V). The arrows indicate the direction of flow.

Lund et al., 1987). While capillary diameter is rather constant $(5 \mu \mathrm{m})$ and seems to be independent of the type of muscle (Potter and Groom, 1983), number and length of the capillaries in a module probably depend on the oxidative capacity of the muscle. Predominantly glycolytic muscles were found to have less and shorter capillaries than mainly oxidative muscles (Myrhage and Hudlická, 1976; Sullivan and Pittman, 1984). Within a vascular unit, sharply defined bundles of capillaries, fed by several functionally terminal arterioles, with no intercapillary connections with adjacent bundles and fed by other arterioles, can be distinguished over the whole length of the unit (Skalak and Schmid-Schönbein, 1986). How these bundles are linked with functional (motorunits) or anatomical (fasciculi) structures is unclear (Renkin et al., 1981; Skalak and Schmid-Schönbein, 1986).

\subsection{Local regulation of blood flow}

The amount of blood flowing through the capillary bed of skeletal muscle is regulated by a complex system, in which the central nervous system (Burnstock and Griffith, 1983; Thompson and Mohrman, 1983; Klabunde, 1986 ; Bevan and Brayden, 1987) and such local factors as transmural pressure, oxygen, adenosine, $\mathrm{pH}$, potassium, lactate, inorganic phosphate, play a role. The site of action of these factors is the wall of small arteries and arterioles. In the muscle at rest, the limited supply meets the low metabolic needs: the arterioles are effectively rather constricted, which results in a slow capillary perfusion (mean flow velocity up to $0.51 \mathrm{~mm} / \mathrm{s}$ : Johnson et al., 1976; Lindbom et al., 1980, 1982; Tyml et al., 1981; McDonagh et al., 1982; Damon and Duling, 1985; Mirhashemi et al., 1987). Disturbance of this balance by reduction of perfusion pressure leads 
to dilation of the arterioles to maintain capillary flow (autoregulation). Muscular exercise leads to wasodilation to bring the supply of blood at a sufficiently high level, resulting in an increased mean capillary flow velocity (Myrhage and Eriksson, 1984; Dawson et al., 1987).

Whether this increase in flow parallels recruitment of previously non-perfused capillaries is unsure. In a number of studies, capillary recruitment has been observed (Duran, 1977; Gorczynski et al., 1978; Honig et al., 1980, 1982; McDonagh et al., 1982; Gray et al., 1983), but in other studies approximately all functionally available capillaries were found to be already perfused at rest (Klabunde and Johnson, 1977" terlein and Schmidt, 1980; Hudlická et al., 1982; Damon and Duling, 1984; Kayar and Banchero, 1985; Tyml, 1986). Differences in methods and animal species used, animal age, and differences from muscle to muscle might underlie this discrepancy.

The increase in blood flow to a skeletal muscle during exercise was observed to parallel a redistribution of blood in favor of the muscle fiber compartment as compared to the connective tissue. In the muscle at rest up to $45 \%$ of the total inflow goes directly to the connective tissue surrounding the muscle fiber compartments (Lewis, 1984; Lindbom and Arfors, 1984; Lindbom, 1986), and does not participate in capillary exchange. During exercise this amount was only $24 \%$ (Lindbom, 1986). Redistribution in reaction to exercise is likely to result from a more pronounced dilation of the terminal arterioles as compared to the transverse arterioles (Lindbom, 1986), which might be due to a greater sensitivity of the terminal arterioles for oxygen (Granger et al., 1976). Two mechanisms are generally accepted to play an important role in the local regulation of blood flow: the myogenic and the metabolic mechanism. The myogenic mechanism deals with the property of blood vessels to react actively upon changes in local transmural pressure, i.e. the pressure difference over the vessel wall. An increase in transmural pressure was found to result in constriction of arterioles (Johnson, 1980; Burrows and Johnson, 1983; Meininger et al., 1987 ${ }^{\mathrm{a}}$ ), while a decrease caused vasodilation (Bouskela and Wiederhielm, 1979; Renernan et al., 1980; Sullivan and Jolnnson, $1981^{\mathrm{a}}$; Morff and Granger, 1982; Meininger, $1987^{\mathrm{b}}$; Slaaf et al., 1987 ). In these studies, the myogenic reaction appeared to be proportional to the degree of changes in transmural pressure. But also the rate at which the changes in transmural pressure were applied was important in the myogenic response (Mellander and Arvidsson, 1974; Grande et al., 1977). The cellular structures involved in the myogenic mechanism are still unknown. According to Johnson $(1978,1980)$, wall tension is the controlled parameter during the myogenic reaction, which implies that some intracellular structure in series with the contractile machinery, for example dense bodies, controls the degree of vascular constriction. According to other investigators (Johansson and Mellander, 1975; Grände and Mellander, 1978), the membrane of smooth muscle cells serves as a sensor. Transmural pressure increases would stretch the membrane. This stretch would facilitate spontaneous depolarizations and therefore result in constriction of the smooth muscle cells.

Another important local regulation mechanism is metabolic control. Since supply of oxygen is one of the main functions of tissue perfusion, most studies have concentrated 
on the role of oxygen in flow regulation. Although increased tissue oxygen tensions reduce flow by constriction of the arterioles (Lindbom et al., 1980; Sullivan and Johnson, 1981. ; Lund et al., 1987), it is unsure whether oxygen acts directly on the contractile machinery of the vascular smooth muscle cells (Pittman, 1981, 1986). In the latter studies, indirect involvement of oxygen is suggested. Lack of oxygen, as in hypoxic tissue, may lead to production of adenosine (Berne, 1986 ; Klabunde, $1986^{\mathrm{b}}$; Burnstock, 1987) or prostaglandins (Pittman, 1981), both well known as potent vasodilators (Hester et al ${ }_{n, 1982}$. Lindbom et al., 1982). But adenosine may also be produced in hyperoxic muscle tissue during submaximal exercise (Proctor and Duling, 1982), indicating that factors other than oxygen are also involved in metabolic control. At this moment, the metabolic control of tissue perfusion is insufficiently understood. It seems to be a complex interplay between several, locally produced substances (Hudlická and Khelly, 1985).

Recent studies indicate that the endothelium might also be involved in local blood flow control. The sensitivity of endothelial cells to oxygen and ATP (Busse et al., 1984; Pittman, 1986; Burnstock, 1987; Pohl et al., 1987) supports this idea. However, the endothelium dependent vasodilation, as induced by pulsatatile flow (Pohl et al., 1986) or increased shear rate (Tesfamariam and Halpern, 1987), cannot be attributed to either myogenic or metabolic control, and indicates that there is a third mechanism in blood flow regulation.

\subsection{Vasomotion: dynamic behavior of arterioles}

Direct intravital observation of the resting skeletal muscle vascular bed demonstrates that perfusion of the capillaries is frequently intermittent (Johnson et al., 1976; Amundson et al., 1980; Johnson, 1980; Lindbom et al., 1980; Shibata and Kamiya, 1985; Dawson et al., 1987; Lund et al., 1987) and that spontaneously occurring rhythmic diameter variations in the feeding arterioles (vasomotion; see figure 2.4) underly this intermittency (Lindbom et al., 1980; Tangelder et al., 1984; Lund et al., 1987; Slaaf et al., 1987 Meyer et al., 1988 ). At first arteriolar vasomotion was only observed in tissues that were easily accessible for intravital microscopic observation with no need for surgical intervention and anesthesia, for example the bat wing (Nicoll and Webb, 1955). The development of refined preparation techniques in combination with appropriate anesthesia resulted in several publications on vasomotion in various tissues. Besides in skeletal muscle (see above) it was found in skin (Intaglietta and Gross, 1982; Funk and Intaglietta, 1983; Colantuoni et al., 1985 ), mesentery (Burrows and Johnson, 1981), cremaster muscle (Hutchins et al., 1974; Faber et al., 1982 ; Meininger, 1987 ${ }^{\mathrm{b}}$ ) and, recently, brain (Hundley et al., 1988; Osol and Halpern, 1988). Vasomotion appeared to be present only in carefully handled preparations during precisely controlled experimental conditions. Inappropriate anesthesia (Faber et al., $1982^{b}$; Colantuoni et al., 


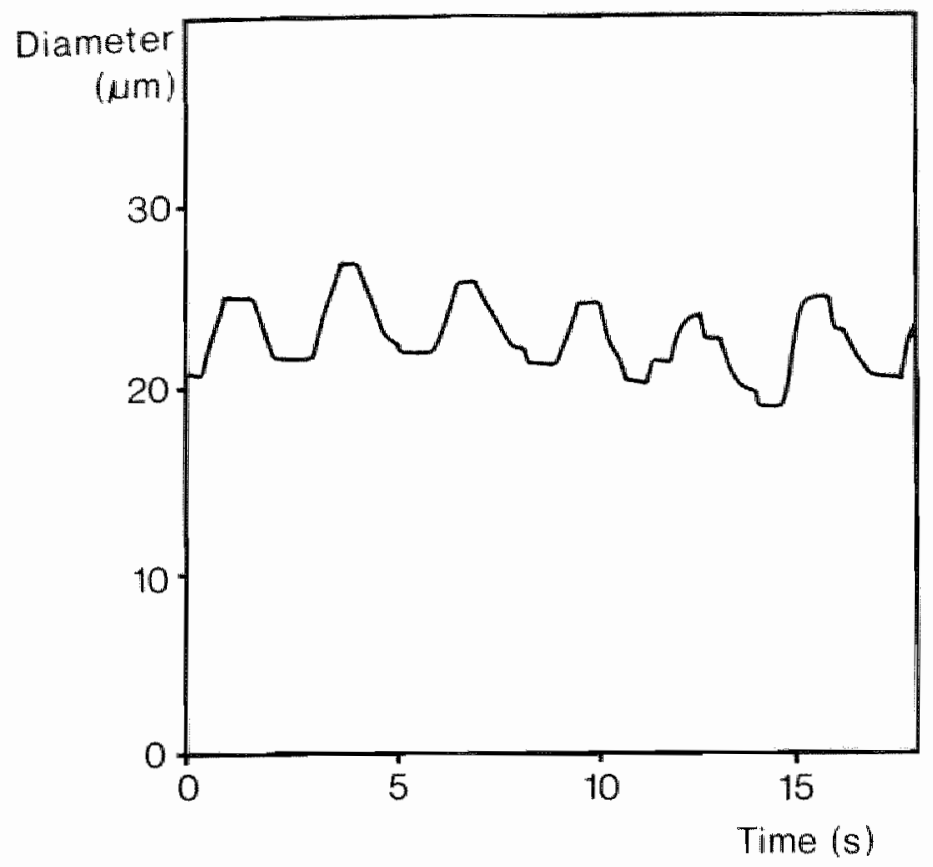

FIGURE 2.4: Typical example of a vasomotion pattern in a tratsverse arteriole of the rabbit tenussimus muscle.

$1984^{a}, 1984^{b}$ ) or trauma of the preparation due to handling (Lindbom et al., 1977; Amundson et al., 1980) resulted in disappearance of vasomotion and an inflammatorylike increase in blood flow. Therefore, it was suggested that vasomotion represents a normal, physiological phenomenon (Funk and Intaglietta, 1.983; Intaglietta, 1983), an idea in accordance with the various reports on the occurrence of flow intermittency, most likely due to vasomotion, in nailfold capillaries of healthy man (Fagrell, 1983). In these various tissues vasomotion has been observed in arterioles at all levels in the vascular tree. In the tenuissimus muscle, however, vasomotion was only observed in the transverse arterioles and their first order side branches. It is unknown whether vasomotion occurs in the central artery, but in the smallest arterioles vasomotion was never observed (Tangelder et al., 1984).

The pattern of vasomotion may be different in different arterioles. In the tenuissimus muscle Slaaf and colleagues $\left(1987^{\mathrm{a}}\right)$ observed a difference in cycle length between the most proximal part of a transverse arteriole and more distally located areas, and superposition of the two patterns in between. Similar observations were made in skin: in large arterioles $(70-100 \mu \mathrm{m})$ the duration of the vasomotion cycle was reported to be long (15-60s), as compared to the cycles between 4 and $8 \mathrm{~s}$ in small arterioles $(<15$ wm; Funk et al., 1983; Colantuoni et al., $1985^{\circ}$ ), while in the arterioles in between superposition of both cycles was observed (Colantuoni et al., 1985 ). The waveform of vaso- 
motion could change abruptly at branching points of arterioles (Tangelder et al., 1984; Colantuoni et al, 1985 ; Meyer et al., 1987 $\mathrm{g}$. In the tenuissimus muscle the cycle length in a first order side branch was always comparable to that in the adjacent segment of its feeding transverse arteriole (Tangelder et al., 1984; Meyer $e t$ al., 1987 $7^{\text {a }}, 1987^{\mathrm{b}}$; Slaaf et al., 1987 ${ }^{\mathrm{a}}$ ).

The pattern of vasomotion could be modified by different interventions. Neural factors (Nicoll and Webb, 1955; Baez et al., 1977; Colantuoni et al., 1984 ; Öhlen et al., 1987), transmural pressure changes (Bouskela and Wiederhielm, 1979; Burrows and Johnson, 1981, 1983; Osol and Halpern, 1988), hemodilution (Mirhashemi et al., 1987), changes in local oxygen tension (Prewitt and Johnson, 1976) and vasodilation (Faber et al., $1982^{\mathrm{a}} ; 1982^{\mathrm{c}}$ ) have been reported to alter the vasomotion pattern or its effect on capillary flow, often referred to as flowmotion, in various tissues. Although these reports are indicative of a relation between vasomotion and the mechanism of blood flow regulation, most interventions were not suited to indicate specifically which factor is responsible for the vasomotion changes.

A consequence of the presence of vasomotion is that capillary flow vellocity and pressure fluctuate continuously. The fluctuations in flow velocity and pressure might have a positive effect on capillary fluid exchange (Intaglietta, 1981). Especially during the phase of no flow, exchange of oxygen and waste products may occur over the whole length of the capillaries. Furthermore, the fluctuating pressure might serve as a mechanism to remove plugged white blood cells. Another consequence of the presence of vasomotion is the reduced local vascular resistance of a vessel showing vasomotion, as compared to a vessel having the same, but constant mean diameter (Funk et al., 1983). However, it is unlikely that vasomotion serves as a mechanism to reduce vascullar resistance because simple vasodilation of a vessel without vasomotion produces the same effect (Meyer, 1988 ${ }^{\mathrm{b}}$ ). A few other speculations about the significance of vasomotion can be found in literature. Chambers and Zweifach (1945) suggested that vasomotion serves to control extent and distribution of the circulation of the capillary bed. Furthermore, vasomotion may cause substantial periodic volumetric displacements in the tissue and therefore may serve as a peristaltic mechanism for lymph transport (Intaglietta and Gross, 1982; Skalak et al., 1984).

The trigger of the vasomotion cycle is still unknown. Although nerve fibers are present near arterioles at all levels of the vascular tree (Wiedeman et al., 1981; Öhlen et al., 1987), it seems unlikely that vasomotion is triggered by the central nervous system: in the different arterioles of the skin no common vasomotion frequency could be detected (Funk et al., 1983; Colantuoniet al., 1984 $4^{\mathrm{a}}$ ). Besides, decerebration (Faber et al., 1982 $1982^{c}$ ) or blockade of the adrenergic receptors (Colantuoni et al., 1984 $4^{\text {b }}$ ) did not abolish vasomotion. Most investigators support the view that vasomotion is triggered locally (Folkow, 1.962; Funk and Intaglietta, 1983; Intaglietta, 1983; Siegel, 1983; Meyer et al., $1987^{\mathrm{a}}$; Osol and Halpern, 1988). Because vasomotion was observed to occur at regular intervals, it has been suggested that it is induced by pacernaker activity of smooth muscle cells (Folkow, 1964; Colantuoni et al., 1984 ${ }^{\mathrm{a}}$, 1985 ; Intaglietta, 1983; Meyer et al., $1987^{b}, 1988^{\mathrm{a}}$ ). Observations in skin microvasculature that a certain vaso- 
motion frequency in a side branch was transmitted into the feeding arteriole both upstream and downstream (Colantuoni et al., 1985), and in skeletal muscle that vasomotion is most prominent in the side branches of the transverse arterioles, sometimes slightly preceding vasomotion in the transwerse arterioles themselves (Meyer et al., $1987^{\mathrm{a}}, 1987^{\mathrm{b}}$ ) led these investigators to the conclusion that smooth muscle cells in the side branches of the main arterioles serve as pacemaker sites. It cannot be excluded that vasomotion is triggered by varying (instead of fixed) initiator sites, because spontaneously occurring contractions are an intrinsic property of vascular smooth muscle cells (Johansson and Somlyo, 1980; Funk and Intaglietta, 1983; Osol and Halpern, 1988), which might originate from fluctuating intracellular enzyme activity (Siegel, 1983). Because so far no electrophysiological data on vasomotion are available, both hypotheses, fixed versus varying pacemaker sites, remain to be proven.

A complicating factor in study of vasomotion is that vasomotion is not always present in preparations which otherwise seem physiologically normal. Whether the absence of vasomotion in these cases is due to the experimental conditions, such as anesthesia (Faber et al., $1982^{\mathrm{b}}$; Colantuoniet al., $1984^{\mathrm{c}}$ ), oxygen tension (Lund et al., 1987) or tissue temperature (Osol and Halpern, 1988) remains unclear. It might also be that the presence or absence of vasomotion can occur as two possible manifestations of the same physiological control mechanism. This idea is in accordance with the observation that the presence of vasomotion in the wing of awake bats varies from day to day (D.W. Slaaf, personal communication). 



\section{MATERIALS AND METHODS}

In this chapter a brief survey is given of the materials and methods, as used in this thesis. For more detailed and specific information the reader is referred to the various chapters.

\section{Animal preparation}

All experiments were performed on tenuissimus muscles of young (5-6 weeks) mixed breed rabbits of either sex, ranging in weight between 700 and $1150 \mathrm{~g}$. Anesthesia was generally performed with urethane ( $20 \%$ solution in saline) administered intravenously.

To facilitate breathing, the trachea was cannulated. A catheter was inserted into the right jugular vein for additional doses of anesthesia. Catheters in the left common carotid artery and the right femoral artery were inserted for infusion of physiological saline to compensate for respiratory fluid losses and for continuous recording of arterial pressures. Pressure in the arteries supplying the hind limbs could be reduced by in flating a cuff around the descending aorta distal to the renal arteries. The reduced pressure was controlled by a feed-back system (Prinzen et al., 1987) and could be set at any level between control pressure and approximately $10 \mathrm{mmHg}$.

\section{$\underline{\text { Tenuissimus muscle preparation }}$}

Preparation of the tenuissimus muscle was performed according to the technique originally described by Reneman and colleagues (1980). After making a skin incision in the left hind limb just above the saphenous vein, and cutting the subcutaneous connective tissue, the biceps femoris muscle was exposed. The tenuissimus muscle was exposed by reflection of the biceps femoris muscle. From its first exposure on, the muscle was suffused with physiological saline. For insertion of a light rod for transillumination of the 

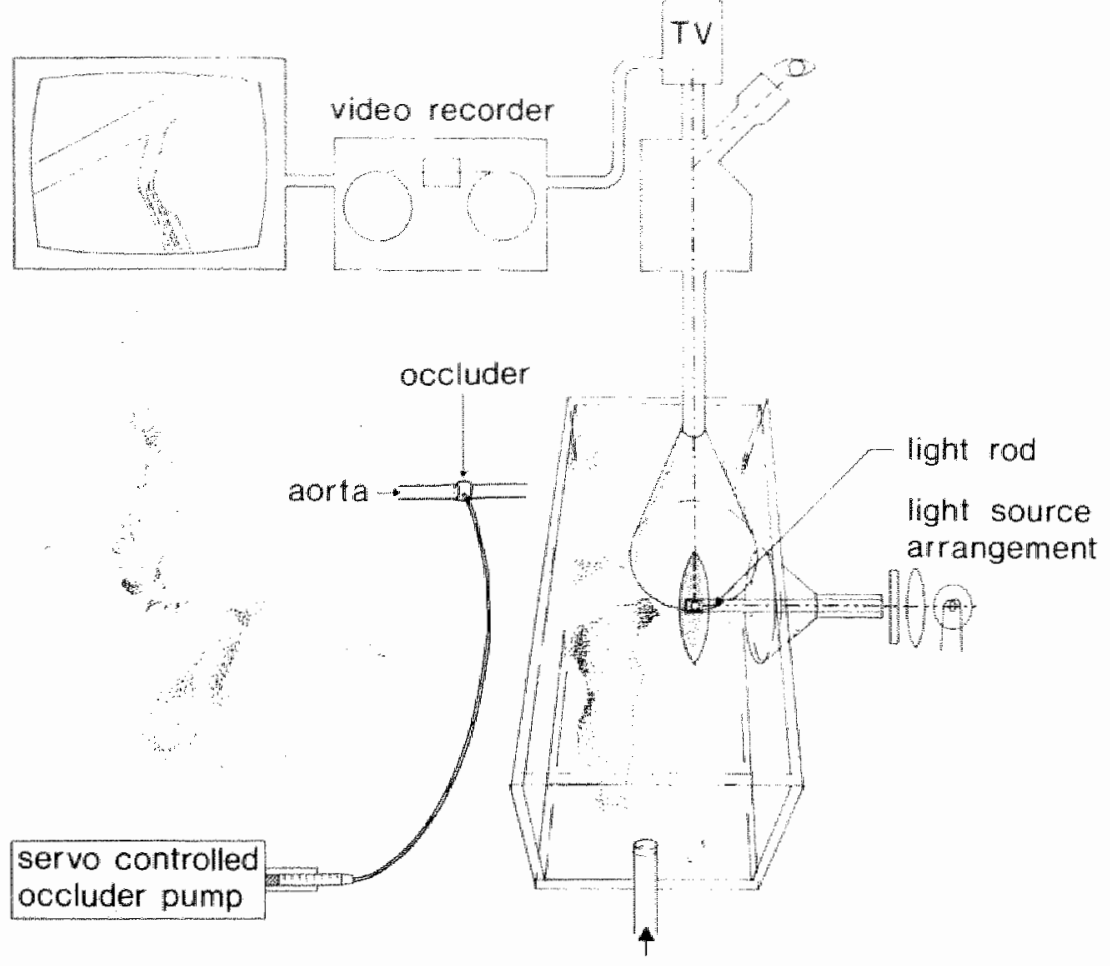

FIGURE 3.1: Schematic representation of the experimental set-up.

muscle, an incision was made in the connective tissue just posterior to the saphenous vein. Subsequently, the left hind limb was placed in a box to control the gas environment of the muscle. Then, the light rod for transillumination was positioned underneath the tenuissimus muscle. The box was sealed and mounted on the stage of a Leitz intravital microscope. Under the microscope, suffusion was performed with Tyrode's or Krebs solution. A schematic representation of the experimental set-up is given in figure 3.1.

\section{Microscopic system}

A Leitz intravital microscope, adapted to telescopic imaging (Slaaf et al., 1982), and Leitz salt water immersion objective lenses were used. The image could be displayed on a monitor through a TV-camera and recorded on video tape for off-line analysis (figure 3.1). A device to measure blood cell velocity, based on the dual-slit photometric principle (Wayland and Johnson, 1967), was placed in front of the TV-camera. Transillumination of the muscle through the light rod system was performed with a 
mercury arc and a light guide. Neutral density filters were used to reduce the light intensity at the muscle to suitable levels. Fluorescence microscopy was performed with an incident fluorescence illuminator, using a Xenon lamp. Fluorescein-isothiocyanatedextran was used as fluorescent plasma label.

\section{Data sampling and processing}

During the experiments, arterial pressures and arteriolar blood cell velocity were measured and stored on video tape simultaneously with the microscopic images with the use of a pulse-code-modulation system (Elmore and Johnson, 1982). Vascular diameters were measured off-line by replaying the videotapes at reduced speed ( $20 \%$ of control) using an image shearing device (Intaglietta and Tompkins, 1973).

The synchronous signals of arterial pressures, blood cell velocity and vascular diameter were digitized by computer and stored on floppy disk. All data were obtained as an instantaneous function of time. From these data, blood flow, reduced velocity, as a measure of wall shear rate, and effective vascular diameter (see chapter 5), as a measure

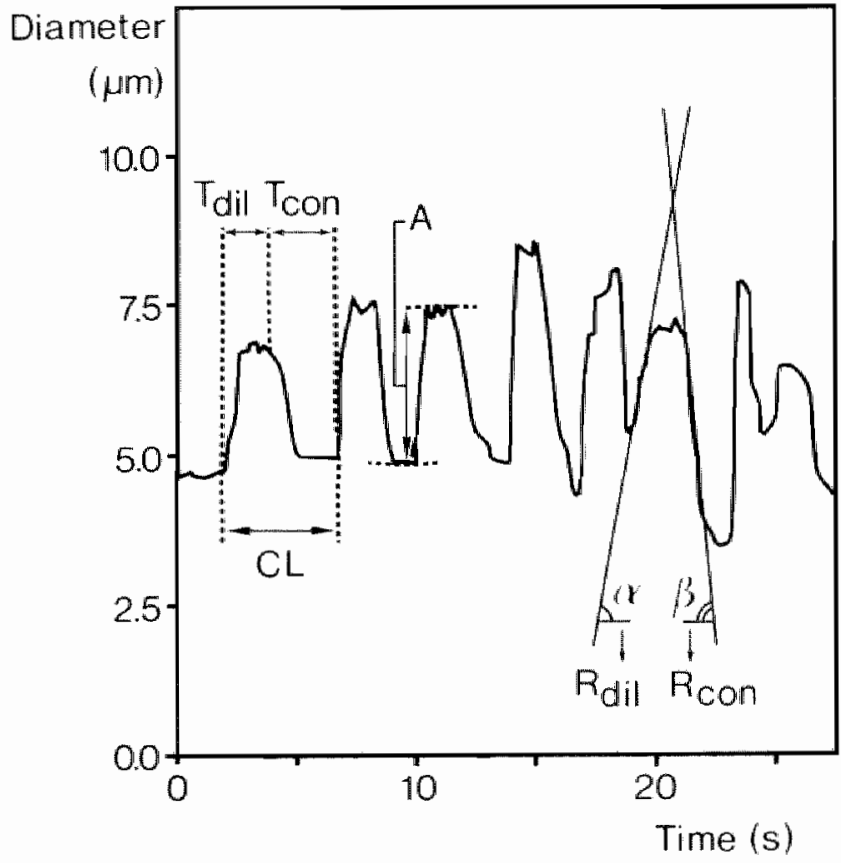

FIGURE 3.2 : Example of a wasomotion pattern in a first order side branch in which vasomotion parameters are indicated: cycle length $(C L)$, amplitude $(A)$, duration of dilation phase ( $T$ till) and duration of constriction phase $\left(T_{\text {con }}\right)$. Rate of dilation $\left(R_{\text {dil }}\right)$ and rate of constriction $\left(R_{\text {con }}\right)$ were calculated from slopes at and B, respectively: 
of mean flow carrying capacity, were calculated.

Vasomotion parameters (see figure 3.2) were derived from the diameter tracings. For each vasomotion cycle, cycle length (CL), amplitude (A), duration of the dilation phase ( $T$ diil), rate of dilation ( $\left.R_{\text {dil }}\right)$, duration of the constriction phase $\left(T_{\text {con }}\right)$ and rate of constriction ( $R_{c o n}$ ) were measured. Furthermore, the relative vasomotion amplitude was calculated by dividing vasomotion amplitude by the mean vascular diameter. Per observation period the mean values of the various parameters were calculated from the diameter tracings recorded in this period. 


\section{DOES CAPILLARY RECRUITMENT EXIST IN YOUNG RABBIT SKELETAL MUSCLE?}

\subsection{Introduction}

Skeletal muscle fibers are supplied with oxygen by the red blood cells travelling through the capillary network. Following maximal exercise muscle blood flow may increase 1015 times, as compared to the control situation (Johnson, 1978), due to dilation of the arterioles. At the capillary level, two mechanisms have been proposed to explain the capability to carry this enormously enhanced muscle blood flow. It has been attributed to an increase in mean red blood cell velocity in already perfused capillaries by some investigators (Burton and Johnson, 1972; Johnson et al., 1976; Vetterlein and Schmidt, 1980; Hudlická et al., 1982) and to both an increase in velocity and an increased number of capillaries perfused, i.e. capillary recruitment (Honig et al., 1980, 1982; McDonagh et al., 1982). In the latter studies on striated muscles $11 \%$ to $58 \%$ of the total number of capillaries, as assessed by counting all capillaries in histologically fixed transverse muscle sections, were found to contain red blood cells (Honig et al., 1980, 1982) or previously infused india ink (McDonagh et al., 1982) at rest.

A study combining in wivo and histological techniques was performed by Lindbom and Arfors (1985) in the rabbit tenuissimus muscle. They compared the number of capillaries perfused at rest, as assessed in wivo by intravital microscopy, with the total num-ber of capillaries, as assessed histologically, and concluded that about half of all capillaries was perfused at rest, indicating that recruitment may occur. Capillary recruitment, however, should be defined relative to the maximal number of functionally available capillaries, $i, e$, the number of capillaries perfused during maximal vasodilation.

Therefore, in the present study we investigated. whether wasodilation, as induced by either administration of adenosine or reactive hyperemia, was associated with an increased number of capillaries perfused. The study was performed in the rabbit tenuissi- 
mus muscle with the use of intravital microscopy. In one series of experiments the number of capillaries stemming from a parent arteriole, which was perfused at rest, was assessed and compared with the number of perfused capillaries stemming from the same arteriole during vasodilation. Capillary recruitment, however, may be accomplished not only by perfusion of previously non-perfused individual capillaries in a partially perfused capillary bed, but also by perfusion of previously non-perfused terminal arterioles, as has been suggested for rat gracilis (Prewitt et al., 1982) and cremaster muscle (Bohlen, 1979; Chen et al., 1981). Therefore, we also investigated whether non-perfused terminal arterioles opened up during vasodilation.

\subsection{Materials and methods}

Animal preparation: sixteen young (5-6 weeks) mixed-breed rabbits of either sex ranging in weight between 850 and $1150 \mathrm{~g}$ were used. The animals were anesthetized with a urethane solution (20\% in saline) administered intravenously. Initially $7.5 \mathrm{ml} / \mathrm{kg}$ was administered in about 7 minutes followed by a supplement of $1.5 \mathrm{ml} 15$ minutes later. If necessary, additional doses were given, generally less than $0.3 \mathrm{ml}$ per hour.

To facilitate breathing, the trachea was cannulated. To compensate for respiratory fluid losses a catheter was inserted into the right jugular vein for continuous infusion of physiological saline $(5 \mathrm{ml} / \mathrm{h})$. Central arterial pressure was recorded via a catheter in the left common carotid artery, using a CTC CP-01 pressure transducer.

Perfusion of the arterioles $(n=9)$ before and after vasodilation was studied in 8 rabbits, while the 8 other rabbits were used for the investigation of capillary perfusion. In the latter animals, an occluder was placed retro-peritoneally around the descending aorta distal to the renal arteries to provoke reactive hyperemia.

Tenuissimus muscle preparation: the tenuissimus muscle preparation has been described in detail elsewhere (Reneman $e t$ al., 1980). In short, a skin incision of about 7 $\mathrm{cm}$ was made just above the saphenous vein of the left hind limb. The subcutaneous connective tissue was cut. Reflection of the biceps femoris muscle and removal of the underlying connective tissue exposed the tenuissimus muscle. Care was taken not to touch the tenuissimus muscle itself. An incision of approximately $3 \mathrm{~cm}$ was made in the connective tissue layer posterior to the saphenous vein, for the insertion of a light pipe for transillumination of the muscle. The left hind paw was subsequently placed in a box (the body remaining outside) that could be sealed to control the gas environment. Then, the light pipe was positioned underneath the tenuissimus muscle and the box was. mounted on the stage of a Leitz intravital microscope.

From its first exposure on, the muscle was superfused with oxygen saturated physiological saline (room temperature). After sealing the box, superfusion of the muscle was 
performed with Tyrode's solution at room temperature saturated with $95 \% \mathrm{O}_{2}$ and $5 \%$ $\mathrm{CO}_{2}$ (actual $\mathrm{pH}=7.25 \pm 0.05$ ). The box atmosphere was still equilibrated with room air. During this period, the flow had to be low in the arterioles and stationary in the capillaries, otherwise the experiment was discarded. The temperature of the Tyrode"s solution was slowly increased to $37^{\circ} \mathrm{C} \pm 0.5^{\circ} \mathrm{C}$ and after about 15 minutes, the saturating gas mixture of the Tyrode's solution as well as of the box was changed to $95 \% \mathrm{~N}_{2}$ and $5 \% \mathrm{CO}_{2}$ (final actual $\mathrm{pH}$ of the Tyrode's solution: $7.35 \pm 0.05$ ). Thereafter the preparation was allowed to stabilize for at least 30 minutes. Only the preparations which then clearly showed vasomotion were used for further analysis. This situation was defined as the control situation. Following this procedure, $70 \%$ of the preparations clearly showed vasomotion with diameter changes of $6-44 \%$, as compared to the mean diameter (Slaafet al., 1987 ${ }^{\mathrm{a}}$ ) and complete closure of the arterioles in reaction to $95 \%$ oxygen.

Microscopic system: the experiments were performed with a Leitz intravital microscope adapted to telescopic imaging according to Slaaf and co-workers (1982). A Leitz salt water immersion objective lens $(25 x$; numerical aperture $=0.6$ ) was used. The image was displayed on a monitor (Siemens, $30 \mathrm{~cm}$ ) through a Bosch-SIT camera $(1 \mathrm{inch}$ ) and recorded on video tape (Sony Betamax) for off-line analysis. The total optical magnification at the front plane of the television camera was $40 \mathrm{x}$.

For transillumination of the muscle, a mercury arc (200W) was used as a light source. Neutral density filters reduced the light intensity through the muscle to a level suitable for the television camera. In addition to the condenser system of the light source, a second condenser system was used in front of the light pipe to improve the resolution in the muscle (Reneman et al., 1980).

Fluorescence microscopy was performed with an incident fluorescence illuminator (Leitz Ploemopak 2.2; interchangeable filter set No. I2). To visualize the lumen of the arterioles a plasma fluorescence label was injected intravenously: $2 \mathrm{ml}$ of a $5 \%$ FTTCdextran (M.W.: 150,000) solution in saline. A Xenon light source (150W) was used.

Perfusion of arterioles: in the tenuissimus muscle, transverse arterioles branch from the central artery and run perpendicularly or obliquely to the muscle fibers. They feed the first order side branches which can be considered to be functionally the terminal arterioles. The pronounced vasomotion of the first order side branches dominates the perfusion pattern of all downstream capillaries. The higher order branches show, despite the presence of smooth muscle cells in the vessel wall, no vasomotion. It cannot be denied that the lack of vascular tone in these higher order branches might be caused by an increased sensitivity of these vessels to the anesthetic agent (Slaaf et al., 1987 $7^{\mathrm{a}}$ ). Only transverse arterioles that showed good contrast between the fluorescent plasma column and its environment for most of their length, were used. An attempt was made to monitor each transverse arteriole from its origin to the edge of the muscle. By fo- 
cussing up and down, special attention was paid to all vessels that could be first order side branches. A vessel was only identified as a perfused first order side branch, when red blood cells could be seen entering it from the transverse arteriole. If this could not be assessed in the monitor image, the eyepiece was used. Overlapping monitor fields ( $\pm 280 \mathrm{~m}$ length) of the transverse arteriole were recorded on videotape, each during 1 minute. This period included at least several vasomotion cycles, since the vasomotion frequency in this skeletal muscle preparation varies between 5 and 32 cycles per minute (Slaaf et al., 1987\%). Superfusion with a Tyrode's solution containing adenosine (final concentration: $10^{-4} \mathrm{M}$ ) resulted in disappearance of vasomotion and pronounced vasodilation in all arteriolar vessels within 5 minutes. Subsequently, the transverse arterioles, as studied in the control situation, were monitored again.

In 8 animals the number of perfused first order side branches of a transverse arteriole was determined before and after vasodilation. The transwerse arterioles $(n=9)$ were copied from the monitor screen by replaying the videotape recorded during the control situation. To this end, the monitor screen was covered with a transparency divided into squares corresponding to the squares on the drawing-paper. Drawings were made of all transwerse arteriolar segments, including their perfused first order side branches. The drawings mounted form a sufficiently accurate map of a transverse arteriole and its perfused first order side branches. Subsequently, the tape of the dilated transverse arteriole was replayed. All perfused first order side branches, according to the definition given above, were drawn in color on the map of the control situation. The results of both situations were compared.

Perfusion of capillaries: to study recruitment of capillaries, 9 capillary beds were monitored in 8 animals, using transillumination. Capillaries visible in one monitor field of view and supplied with blood by the same parent arteriole were studied. Such a precapillary arteriole was a distal branch of a first order side branch, mostly being a second or third order branch of the transverse arteriole. The capillary beds were recorded on videotape during at least 10 seconds, thus including some wasomotion cycles (see above). Then aortic occlusion was performed during 45-90 seconds. The cuff was released thereafter to induce reactive hyperemia. For all capillary beds this procedure was repeated 2 to 4 times to diminish bias of the results caused by leukocyte plugging (Bagge and Braide, 1982). The time delay between the procedures ranged from 2.5-22 minutes (median: 5 mimutes). The number of capillaries perfused in both situations was determined by replaying the recorded tapes. For only those capillaries having the lowest velocities red blood cell velocity was estimated by measuring the time for red blood cells to move across the monitor screen. 


\subsection{Results}

The median arterial blood pressure in all animals was $84 \mathrm{mmHg}$ ( $\mathrm{mange} 74-98 \mathrm{mmHg}$ ). A map of a transwerse arteriole with its perfused first order side branches is shown in figure 4.1. In most cases, the proximal part (about $1 \mathrm{~mm}$ ) of the transverse arteriole could not be observed in focus. Most of the transverse arterioles dichotomized one or more times. In 5 out of 9 arterioles an arcading connection was observed between one of these branches and a neighbouring transverse arteriole within the muscle tissue itself. The dual flow input of such a connection often caused pendulating flow. Other transverse arterioles did not arcade and ran directly from the central artery to the anterior fascia. In one case the transverse arteriole formed an arcading connection with itself. From all transverse arterioles first order side branches sprouted, which divided several times and finally supplied the capillaries with blood (figure 4.1). More than $85 \%$ of all transverse arterioles ultimately ran into the anterior fascia where they formed arterio-venous shunts, which ranged in diameter from 5-11 um.

Table 4.1 Perfusion of first order side branches

\begin{tabular}{|l|c|c|c|c|c|c|c|c|c|c|}
\hline $\begin{array}{l}\text { Number of FOS } \\
\text { perfused }\end{array}$ & control & 14 & 26 & 14 & 18 & 14 & 4 & 18 & 6 & 1 \\
\cline { 2 - 7 } & adenosine $^{\mathrm{b}}$ & 14 & 26 & 14 & 18 & 14 & 4 & 18 & 6 & 1 \\
\hline $\begin{array}{l}\text { Total length }(\mu \mathrm{m}) \text { of the trans- } \\
\text { verse arterioles examined }\end{array}$ & 4000 & 5130 & 3050 & 3040 & 6400 & 3740 & 5960 & 1520 & 1200 \\
\hline
\end{tabular}

"Number of perfused first order side branches (FOS), originating from one transwerse arteriole;

${ }^{6} 10^{-4} M$, applied topically"

Data from 9 different atterioles in 8 rabbits.

Perfusion of first order side branches: the number of red blood cell perfused first order side branches was determined before and after vasodilation in 9 transverse arterioles in 8 rabbits." The length of the transwerse arterioles studied varied between 1200 and $6400 \mu \mathrm{m}$ (table 4.1 ). In the control situation, rhythmic changes in the vessel diameter (vasomotion) were seen in both the transverse arterioles and the first order side branches. Vasomotion disappeared after topical application of $10^{-4} \mathrm{M}$ adenosine; the transverse arterioles dilated to 2.23 (median value; range 1.36-3.29) times the mean control diameter. In five experiments the adenosine concentration was increased to $10^{-3}$ M. No further increase in diameter was observed. All first order side branches periused in the dilated state were also perfused at rest (table 4.1). No recruitment of first order side branches was observed. 


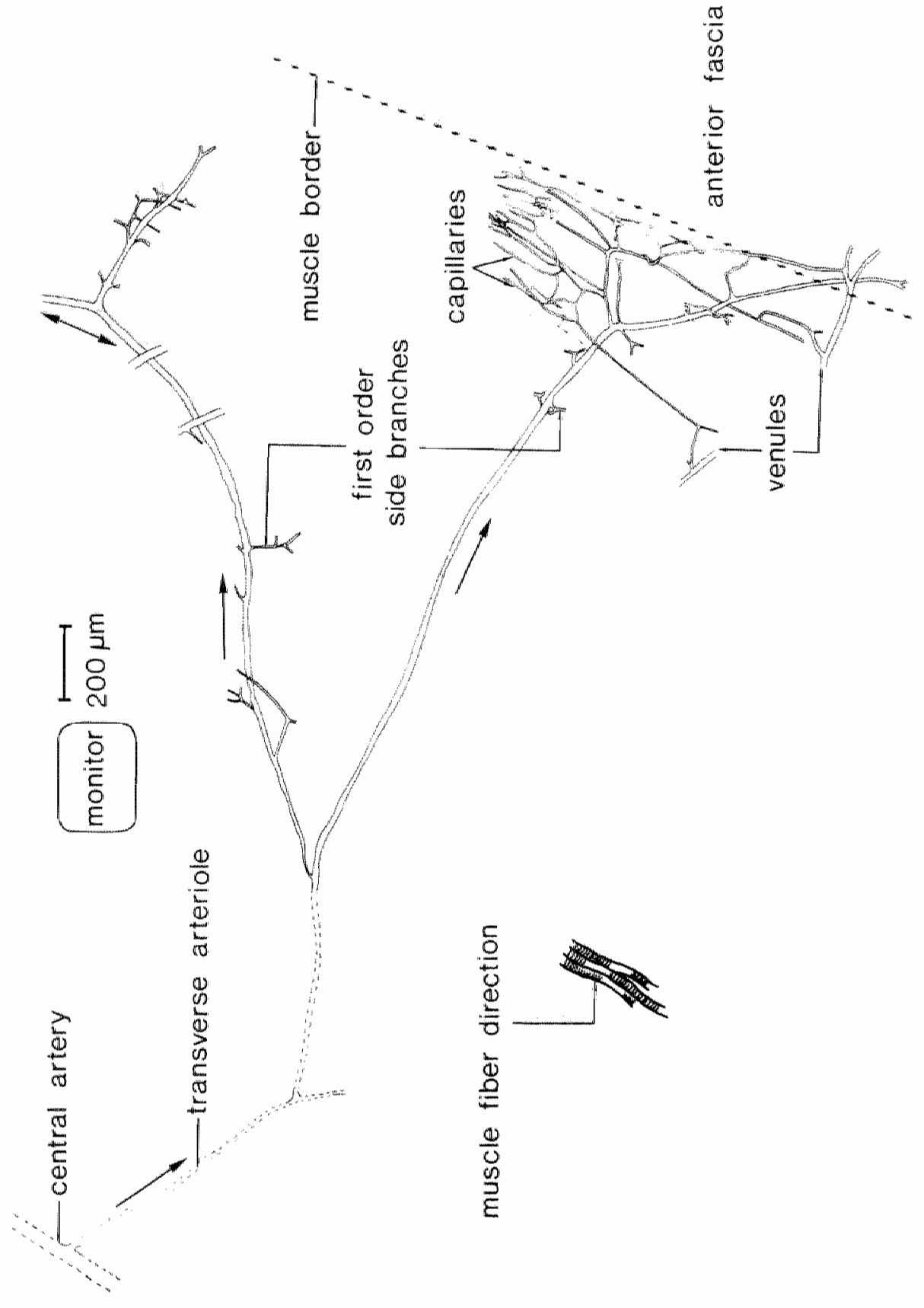


Perfusion of capillaries: capillary recruitment was assessed in 9 capillary beds in 8 rabbits. In the control situation, blood flow in all 65 observed capillaries fluctuated periodically and synchronously in the capillaries fed by the same parent arteriole. In only 5 capillaries a relatively low maximal velocity was observed (estimated velocity less than $100 \mu \mathrm{m} / \mathrm{sec}$ ). During reactive hyperemia flow was continuous in all 65 capillaries. Even in the capillaries with the lowest velocities, the estimated velocity was more than 150 $\mu \mathrm{m} / \mathrm{sec}$. No additional capillaries could be found during reactive hyperemia. When the procedure was repeated two to four times, identical results were obtained. No recruitment of capillaries was observed.

\subsection{Discussion}

In the present study the perfusion of the terminal vascular bed of the tenuissimus muscle was investigated by direct assessment of the number of capillaries and terminal arterioles perfused by red blood cells at rest and during vasodilation. In this preparation no recruitment, i.e. perfusion of an increased number of microvessels, was observed during vasodilation.

It seems unlikely that the present findings are caused by lack of vascular tone in the transverse arterioles and first order side branches in the control situation because all arterioles showed vasomotion and constricted when exposed to oxygen. Reactivity to $\mathrm{O}_{2}$ is considered to be a good criterion for vessel tone (Lindbom et al., 1980; Klitzman and Johnson, 1982; Proctor and Duling, 1982; Morff and Granger, 1983). Moreover, all arterioles dilated in response to the potent vasodilator adenosine (Bockman et al, 1976; Proctor and Duling, 1982). It is likely that complete smooth muscle cell relaxation was obtained during adenosine superfusion because a 10 times higher adenosine concentration did not cause a further increase in arteriolar diameter. Morff and Granger (1983) found that in rat cremaster muscle a concentration of $10^{-4} \mathrm{M}$ of topically applied adenosine was sufficient to maximally dilate second and third order arterioles (about $60 \%$ compared to the mean control diameter). In the present study complete disappearance of vasomotion and doubling of the transverse arteriolar diameter, as compared to the control situation, was observed during adenosine superfusion $\left(10^{-4} \mathrm{M}\right)$.

To investigate whether recruitment of individual capillaries occurs, vasodilation was provoked by inducing reactive hyperemia following the release of an occlusion of the abdominal aorta for 45-90 seconds. According to Johnson and colleagues (1976), peak

FIGURE 4. I: Drawing of a transverse arteriole (running from the central antery to the anterior fascia) and its first order side branches. The arrows indicate the direction of flow. The dashed parts of the transverse arteriole were not in focus. One branch nuns more or less directly to the anterior fascia; the other branch forms a connection (arcade) with a neighboring transverse anteriole. The two-sided arrow indicates pendulating flow. From the arcading branch, one major branch mins to the anterior fascia. 
flow in the capillaries of cat sartorius muscle reaches its maximal level after occlusion durations of 30-60 seconds. Similar observations were made in rat cremaster muscle (Messina et al., 1977). The main reason for not using reactive hyperemia in studying recruitment of arterioles in the present study is the relatively short duration of the peak flow: Between 10 and 60 seconds after a one minute occlusion (Burton and Johnson, 1972; Johnson et al., 1976; Messina et al., 1977; Tuma et al., 1977). In our experiments the recording on tape of a dilated transverse arteriole takes 5-10 minutes, so several occlusions would have been necessary for visualization of the complete arteriole. Since Hester and co-workers (1982) did not observe a difference in blood flow increase between reactive hyperemia and adenosine infusion in isolated dog gracilis muscle, and Messina and colleagues (1977) found an increase in arteriolar diameter of 30-100\% after one minute occlusions (a value in agreement with the increase of approximately $100 \%$ after adenosine superfusion found in the present study), we feel that the arterial occlusion as used in the capillary experiments was a suitable method to obtain maximal vasodilation curing a limited period of time.

The finding in the present study that there is no microvessel recruitment during vasodilation in the tenuissimus muscle of young rabbits demonstrates that in this preparation an increase in blood flow is accomplished by an increase in mean blood flow velocity. The intermittent capillary perfusion pattern will change into a continuous one. Intermittent perfusion of the capillary bed in the resting muscle might be more efficient for supplying oxygen to the tissue than continuous perfusion. Vasomotion creates a fluctuating pressure over the capillary bed. At the highest pressure level, all capillaries are perfused at a relatively high velocity, resulting in short diffusion distances providing an optimal supply of oxygen to the muscle fibers. Constriction of the feeding arteriole results in large plasma gaps between the red blood cells since red blood cells cannot enter the vessel anymore. Complete constriction will result in flow arrest so that exchange may occur over the whole length of the downstream capillaries. The subsequent dilation of the feeding arteriole refreshes the capillary blood. In preparations without vasomotion, however, the pressure difference over the capillary bed is constant and does not reach the peaks as during vasomotion. It might be that without vasomotion at rest only capillaries with lower resistance (shorter in length and wider in diameter) are perfused so that a number of capillaries will be additionally perfused during vasodilation.

In a comparable in vivo study in the same muscle preparation Lindbom and Arfors (1985) also found all first order side branches to be perfused at rest. Furthermore, these investigators compared the number of capillaries perfused at rest, as assessed in vivo by intravital microscopy, with the total number of capillaries, as assessed histologically. Their observations suggest that half of the capillaries downstream of a first order side branch is not perfused at rest. This is in agreement with the data of Gorczynski and coworkers (1978), who observed in an in vivo study in hamster cremaster muscle that twice as many capillaries were perfused during functional hyperemia than at rest. The observations of Lindbom and Arfors (1985) and Gorczynski and colleagues (1978) are in disagreement with our findings. This discrepancy may be explained by the fact that in the 
present study the experiments were performed only on preparations that clearly showed vasomotion, which was not the case in the two other studies (Gorczynski et al., 1978; Lindbom et al., 1980). For reasons given above, it is likely that in preparations showing vasomotion more capillaries are perfused at rest, albeit intermittently. The observation of Gorczynski and co-workers (1978) that many of the capillaries recruited during contraction were side branches of capillaries perfused at rest supports this explanation. An additional explanation for the discrepancy between their results and ours might be the definition of the lowest velocity at which a capillary is still considered to be perfused. In the present study, five capillaries were obserwed with peak red blood cell velocities less than $100 \mathrm{~mm} / \mathrm{sec}$. In studies using lower magnifications, these capilaries might be defined as not perfused, which would result in a calculated capillary recruitment of $8 \%$. This is in the same order of magnitude as found by Hudlicks and co-workers (1982). Considering red blood cell containing capillaries in histologically fixed transwerse muscle sections (Honig et al., 1980, 1982) as being perfused might also lead to different conclusions about capillary recruitment. In our tenuissimus muscle preparation plasma gaps between red blood cells of more than $100 \mu \mathrm{m}$ could regularly be observed as a result of vasomotion in the first order side branches. In fixed muscle sections, these capillaries might easily be taken for permanently unperfused, because capillaries could not be tracked for more than $50 \mu \mathrm{m}$ (Honig et al., 1980). In reality, they could have been unperfused for only a short period of time.

It is debatable whether the conclusions of the present study can be generalized for skeletal muscle. Intravital microscopy of transverse arterioles and first order side branches in the tenuissimus muscle is restricted to very thin muscles. This means in fact that only young (5-6 weeks) rabbits can be used. Sarelius and colleagues (1981) found no difference in the number of capillaries perfused when comparing resting conditions and maximal vasodilation in cremaster muscles of young (5 weeks) hamsters. In 19 weeks old animals, however, they observed an increase of approximately $40 \%$ in the number of capillaries perfused in the dilated state. In gracilis muscle of WKY rats Prewitt and co-workers (1982) found all arterioles to be open at rest in young (6-8 weeks) rats, but observed that in adult rats $(16-18$ weeks) $12 \%$ of the small arterioles $(<20$ $\mu \mathrm{m})$ were closed in the control situation.

In conclusion no recruitment of capillaries or first order side branches was found in young rabbit tenuissimus muscle preparations in situ when the blood vessels were maximally dilated. Increased blood flow was associated with disappearance of vasomotion and a continuous capillary flow at increased velocity.

\subsection{Summary}

Recruitment of terminal arterioles and capillaries was studied in the tenuissimus muscle of 16 young urethane anesthetized rabbits. In one set of experiments ( 8 ani- 
mals) intravital fluorescence microscopy was used to visualize transverse arterioles and to assess the number of their first order side branches (functionally the terminal arterioles) perfused with red blood cells before and after vasodilation $\left(10^{-4} \mathrm{M}\right.$ adenosine, applied topically). In another set of experiments ( 8 animals) the number of muscle capillaries perfused with red blood cells from the same parent arteriole was determined at rest and during vasodilation (reactive hyperemia), using bright field microscopy. All capillaries and first order side branches that were perfused during vasodilation were also perfused at rest. These findings indicate that in this skeletal muscle preparation no recruitment of arterioles or capillaries occurs in an anatomical sense of the word. 


\section{EFFECTIVE DIAMETER AS A DETERMINANT OF LOCAL VASCULAR RESISTANCE IN THE PRESENCE OF VASOMOTION}

\subsection{Introduction}

In resting tissues the arteriolar diameter often varies with time in a cyclic way (vasomotion) and causes vascular resistance to be time dependent. Considering only geometrical factors, mean vascular resistance, defined as the temporal mean of the resistance over one vasomotion cycle, does not only depend on mean vascular diameter and vasomotion amplitude (Funk et al., 1983), but also on the pattern of vasomotion. Vasomotion cycle length per se does not influence mean vascular resistance (Funk et al., 1983), unless there is also a change in the pattern of vasomotion. The suggestion that vasomotion lowers vascular resistance, as compared to that of a vessel with the same mean diameter but without vasomotion, is correct, but misleading. This would indicate that in a certain physiological state mean vascular diameter is regulated rather than flow. However, it is more likely that an organ receives the same amount of flow whether or not its arterioles show vasomotion. Hence, reference should be made to the diameter value indicative of the flow carrying capacity of the vessel.

The complicated interplay between the different vasomotion parameters (amplitude, rate of dilation or constriction, and shape) makes it difficult to appreciate in a direct, unambiguous way the extent of their influence on vascular resistance. "To avoid this problem it is proposed to calculate from the actual diameter tracings the effective diameter, defined as the diameter of a tube with constant diameter and the same vascular resistance as the vessel showing vasomotion. Model calculations were performed for square wave, sinusoidal, and triangular vasomotion patterns and the results obtained were compared with those obtained from vasomotion patterns in rabbit tenuissimus muscle arterioles. 


\subsection{Methods}

Principle: to calculate the contribution of vasomotion to the resistance and flow carrying capacity of a microvessel, cylindrical vessel segments of equal length and uniform diameter were compared. With the use of Poiseuille's law and assuming that the rheological properties of blood are constant, flow as an instantaneous function of time $(Q(t))$ is proportional to $D^{4}(t)$, where $D(t)$ is the instantaneous vessel diameter and $t$ is time (Burton, 1972). For a constant pressure gradient along the vessel segment, mean blood flow $(\mathrm{Q})$ can be computed from:

$$
Q=B \int_{0}^{T} D^{4}(t) d t / \int_{0}^{T} d t
$$

where $T$ is vasomotion cycle length and $\beta$ a proportionality factor.

The effective diameter $\left(D_{\text {eff }}\right)$, defined as the diameter of a tube with uniform constant diameter without vasomotion and the same flow carrying capacity as the wessel showing vasomotion, was calculated from $Q=\beta D^{4}$ eff yielding:

$$
D_{\text {eff }}=\sqrt[4]{\int_{0}^{T} D^{4}(t) d t / T}
$$

Using this equation $D_{\text {eff }}$ was calculated from actual in vivo diameter tracings (figure 5.1) obtained from the experiments described in chapter 6 . The diameter data were digitized at a sampling rate of $10 \mathrm{~Hz}$ using a $12 \mathrm{bit} \mathrm{A} / \mathrm{D}$ converter and were stored on floppy disk. Computations were performed on a DEC MINC-11 computer. The integration process of the digitized data was performed by summing the fourth power of each sample point, $\mathrm{D}_{\mathrm{i}}$, and dividing the result by the number of samples:

$$
D_{\text {eft }}=\sqrt[4]{\sum_{i=1}^{N} D_{i}^{4} d t / N}
$$

The integration process was performed over an integer number of vasomotion cycles. Since at least 4 vasomotion cycles were taken and the sampling frequency of $10 \mathrm{~Hz}$ is much higher than the vasomotion frequency $(0.2-0.5 \mathrm{~Hz})$ the error can be estimated to be far less than $1 \%$.

Defining vascular hindrance $(\mathrm{H})$, by taking into account only the geometrical factors of resistance, mean vascular hindrance $(\overline{\mathrm{H}})$ over one vasomotion cycle is inversely proportional to mean flow, assuming the pressure gradient to be constant (Burton, 1972): $\overrightarrow{\mathbf{H}} \equiv 1 / \mathrm{Q}$. The ratio of hindrances of two vessels with different effective diameters can 


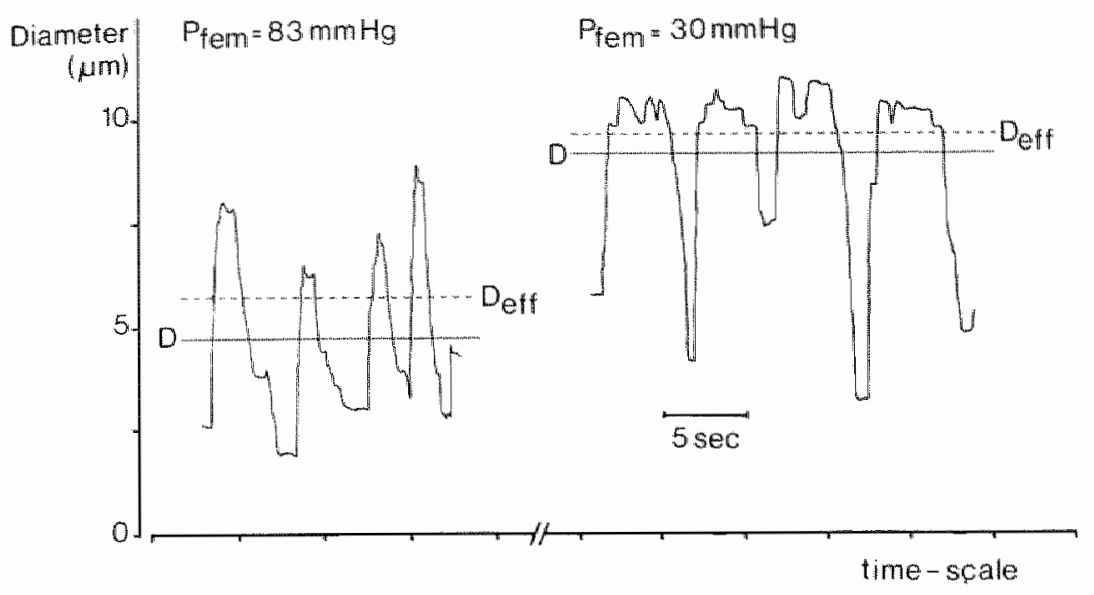

FIGURE 5.1: Vasomotion patem of a first order side branch of a transverse arteriole in the rabbit tenuissimus muscle at two different perfusion presinure levels ( $\left.P_{\mathrm{fen}}\right)$.

be calculated according to:

$$
\tilde{\mathrm{H}}_{1} / \tilde{\mathrm{H}}_{2}=\left(\mathrm{D}_{\text {eff } 2} / \mathrm{D}_{\text {eff } 1}\right)^{4}
$$

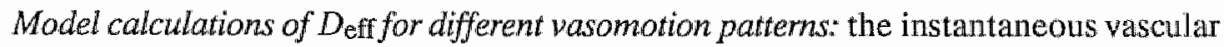
diameter $D(t)$ consists of a constant part $D$ and a time dependent part $A(t)$, this is $D(t)=D+A(t)$. The peak-to-peak difference of the time dependent part $A(t)$ is $A$. $D_{\text {eff }}$ is calculated using equation 2 . Integration was performed analytically over one vasomotion cycle using the equations of the waveforms as given in the appendix.

\section{Square wave vasomotion}

In this case (figure 5.2A) it holds that

$$
\mathrm{D}^{4} \operatorname{err}(\mathrm{Sq}, \mathrm{b}, \mathrm{D}, \mathrm{A})=\mathrm{b}(\mathrm{D}+0.5 \mathrm{~A})^{4}+(1-\mathrm{b})(\mathrm{D}-0.5 \mathrm{~A})^{4}
$$

where coefficient $b$ describes the fraction of time spent in the dilated state. Only if 
A

D

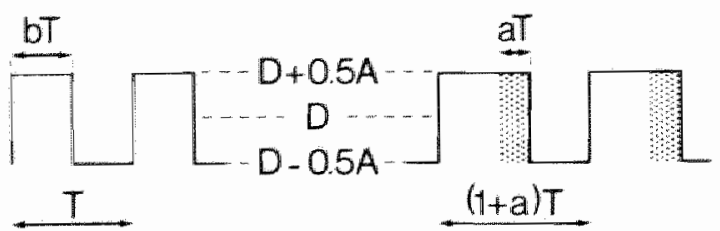

0

B
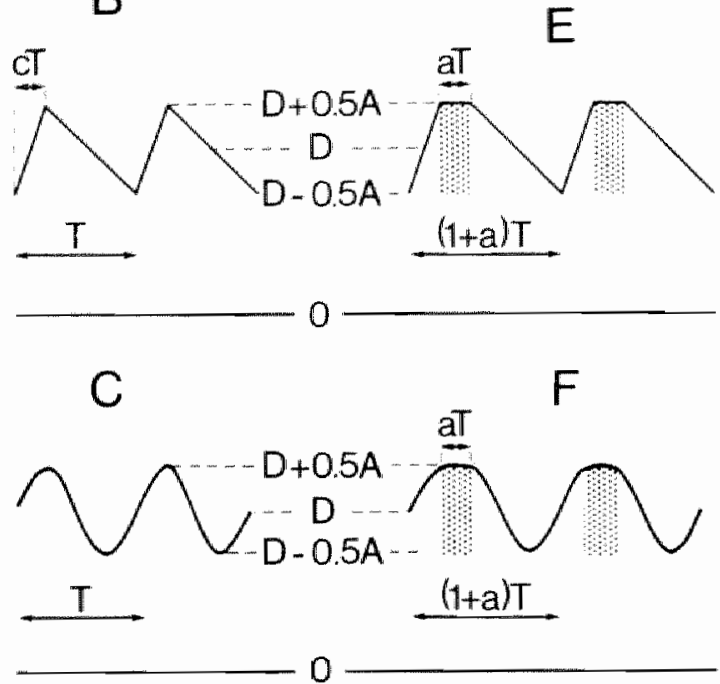

FIGURE 5.2: Schematic representation of three vasomotion patterns. A. square-wave; coefficient b denotes the fraction of time spent in the wasoditated state. $B$. triangular pattern; coefficient $c$ denotes the froction of lime spent in the vasodilating state. $C$. sinusoidal wave pattern. In $D, E$ and $F$ the vasosnotion cycle length is increased by a fractional period a T, during which the vessel remains in the vasodilated state (hatched area).

$\mathrm{b}=0.5$ it holds that $\overline{\mathrm{D}}$ (mean vascular diameter over one vasomotion cycle) equals $\mathrm{D}$. In this approach the result obtained is independent of the cycle length. However, if the vasomotion cycle length is changed by adding to each initial vasomotion cycle a fractional period a $\mathrm{T}$ (figure $5.2 \mathrm{D}$ ), during which the vessel remains in the vasodilated state $(\mathrm{D}+0.5 \mathrm{~A})$, the following relation has to be used:

$$
D^{4}{ }_{e r f}(S q, b, D, A, a)=\left[(b+a)(D+0.5 A)^{4}+(1-b)(D-0.5 A)^{4}\right] /(1+a)
$$


In this situation the result is independent of the actual shape of the triangle:

$$
D^{4} \operatorname{err}(T r, c, D, A, a)=\left[(D+0.5 A)^{5}-(D-0.5 A)^{5}+5 a A(D+0.5 A)^{4}\right] / 5 A(1+a)
$$

Coefficient c, proportional to the steepness of the rise (cT/A) (figure 5.2B), does not appear in the results. If $\mathrm{a}=0$ it holds that $\overrightarrow{\mathrm{D}}=\mathrm{D}$.

\section{Sinusoidal shape of vasomotion (figures $5.2 \mathrm{C}, 5.2 \mathrm{~F}$ )}

In this situation the result is given by:

$$
D_{\mathrm{efr}}^{4}(\mathrm{Si}, \mathrm{D}, \mathrm{A}, \mathrm{a})=\mathrm{D}^{4}\left[1+\mathrm{a}+2 \mathrm{a}\left(\frac{\mathrm{A}}{\mathrm{D}}\right)+\frac{3+6 \mathrm{a}}{4}\left(\frac{\mathrm{A}}{\mathrm{D}}\right)^{2}+0.5 \mathrm{a}\left(\frac{\mathrm{A}}{\mathrm{D}}\right)^{3}+\frac{3+8 \mathrm{a}}{128}\left(\frac{\mathrm{A}}{\mathrm{D}}\right)^{4}\right] /(1+\mathrm{a})
$$

Again if $a=0$ it holds that $\bar{D}=D$.

Data presentation: for convenience of interpretation, the data presented in the figures are normalized: $D_{\text {eff }}$ to $\mathrm{D}$ and vasomotion amplitude to $2 \mathrm{D}$.

\subsection{Results and discussion}

Superposition of a symmetric vasomotion pattern on a constant diameter D leads to an increase in effective diameter and a concomitant decrease in hindrance. In figure 5.3 the relative effective diameters are plotted as a function of the relative vasomotion ampiitude $(A / 2 D)$ for the three different patterns of vasomotion: a symmetric square wave $(b=0.5)$, and a sinusoidal and a triangular pattern. The straight line indicates the increase of $D_{\text {eff }}$ for a tube with uniform constant diameter $\mathrm{D}+0.5 \mathrm{~A}$, which represents the upper bound of the effect of vasomotion on the effective diameter.

Consider the case of a square wave with $\mathrm{A}=2 \mathrm{D}$, which means that during the vasomotion cycle the vascular lumen completely closes, as frequently occurs in the functionally terminal arterioles of the rabbit tenuissimus muscle. In this case $D_{\text {eff }}=2 \mathrm{D} \sqrt[4]{\mathrm{b}}$ (see formula 5). Therefore, if the arteriole is open to flow at a diameter of $2 \mathrm{D}$ during only $6.25 \%\left(=(0.5)^{4} .100 \%\right)$ of the vasomotion cycle, it has the same resistance to flow as a 


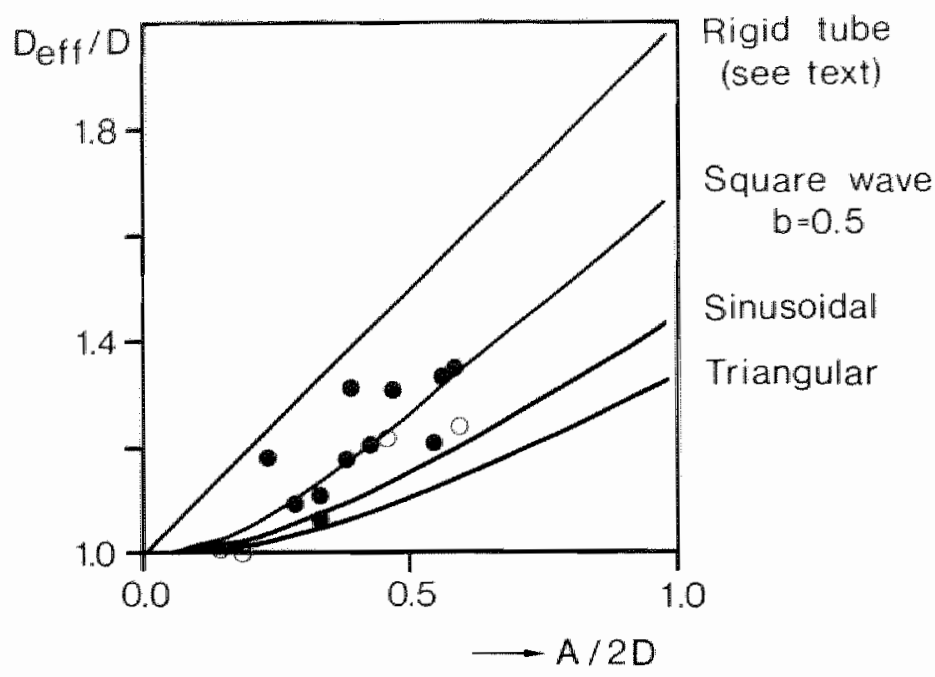

Figure 5.3: Normalized effective diameler $\left(D_{\text {eff }} / D\right)$ as a function of relative vacomotion amplitude (A/2D). The straight line depicts the effective diameter of a rigid tube with the diameter $D+0.5 A$. Data calculated from in wivo tracings yrom transverse arterioles (o) and first order side branches ( $\bullet$ ) are indicated.

vessel with constant diameter $D$. This is indicated by the fact that in both cases $D_{\text {eff }}=\mathrm{D}$, although in the former case the mean diameter is only $0.125 \mathrm{D}$. If the functionally terminal arteriole is open (at $2 \mathrm{D})$ during $50 \%$ of the vasomotion cycle $(b=0.5)$ the effective diameter reaches a value of $1.68 \mathrm{D}$. If in this case vasomotion ceases and the diameter becomes constant at $2 \mathrm{D}$, the hindrance is only reduced by a factor of 2 . In case of a sinusoidal or triangular vasomotion pattern with complete closure during part of the cycle, cessation of vasomotion, resulting in a constant diameter of $2 \mathrm{D}$, reduces hindrance by a factor of 3.7 and 5.0, respectively.

An increase in vasomotion cycle length by adding a fractional period (aT), during which the vessel remains in the vasodilated state (2D), leads to an increase of $D$ eff as is shown in figure 5.4. This increase is most pronounced for the pattern with initially the smallest influence on $D_{\text {eff }}$ (the triangle). In the range of relative cycle length changes, as observed in the rabbit tenuissimus muscle during reduction of perfusion pressure (a $\leq$ 0.4 ), $D$ eff becomes maximally 1.79D, 1.67D, and 1.62D (square wave $(b=0.5)$, sinusoidal pattern and triangular pattern, respectively). This means a reduction of hindrance by a factor of $1.29,1.76$, and 2.13 , respectively.

In transverse arterioles of rabbit tenuissimus muscle the vasomotion amplitude hardly exceeds $0.5 \mathrm{D}$. The effective diameters for a vessel with a vasomotion amplitude of

Figure 5.4 Normalized effective diameter ( $D_{\text {eff }} D$ ) as a function of the coefficient " $a$ " for different vasomotion amplitudes (A) stuperimposed on a constant diameter $D$. Coefficient' 'a' deternines the increase in cycie length by the fractional period a $T$, which is spent in the vasodilated state $(D+0.54)$. 

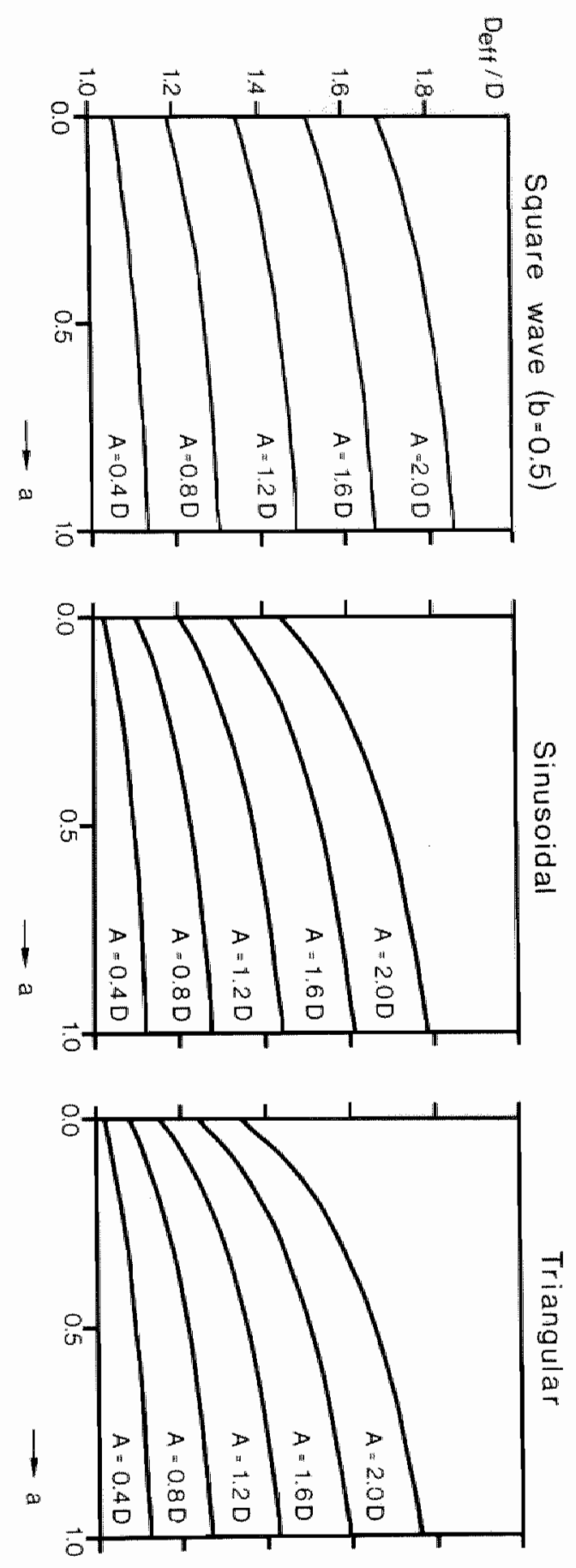
$0.5 \mathrm{D}$ are $1.08 \mathrm{D}, 1.04 \mathrm{D}$, and $1.03 \mathrm{D}$ (square wave, sinusoidal pattern and triangular pattern, respectively). An increase in vasomotion cycle length by $40 \%$ at a diameter equal to the maximum during the vasomotion cycle (1.5D) would increase $\mathrm{D}_{\text {eff }}$ to $1.14 \mathrm{D}$, $1.12 \mathrm{D}$, and $1.11 \mathrm{D}$, respectively. The significance of these relatively small changes in diameter becomes evident when the fourth power of the diameter is taken to calculate the relative hindrance. $A D_{\text {eff }}$ of $1.08 \mathrm{D}$ and $1.14 \mathrm{D}$ implies a relative hindrance of 0.74 and 0.59 , respectively. Although this effect is considerable, it is still limited if compared to that of a dilation to a constant diameter of $1.5 \mathrm{D}$, the maximal diameter during vasomotion. In this case the relative hindrance would be reduced to 0.20 .

The use of the entity 'effective diameter' also eliminates complications if two factors are opposing. It is difficult to appreciate in a direct, unambiguous way whether a vessel with a mean diameter of $25 \mathrm{~m}$ and with a sinusoidal vasomotion pattern with a peakto-peak amplitude of $5 \mu \mathrm{m}$ has a higher or a lower hindrance than a vessel with a mean diameter of $22 \mu \mathrm{m}$ and a vasomotion amplitude of $22 \mu \mathrm{m}$. Comparison of their effective diameters, however, yields that these are virtually the same $(25.2 \mu \mathrm{m}$ and $25.4 \mu \mathrm{m}$, respectively), indicating that the vessels have the same mean hindrance and flow carrying capacity.

The scatter of the in vivo data shown in figure 5.3 demonstrates that the patterns cannot be approximated by a mean diameter, a vasomotion amplitude and one type of pattern. The model calculations are based on symmetric vasomotion patterns, whereas the vasomotion patterns in wivo are often asymmetric. The actual mean vessel diameter is considerably less than that calculated as the mean of the highest and lowest values during vasomotion. Corrections for this asymmetry are less relevant, since shape changes can still have a considerable influence as is shown by the model calculations.

In the present study the rheological factors have been assumed to be constant throughout the vasomotion cycle. However, the relative hematocrit in capillaries and terminal arterioles varies during the vasomotion cycle (Fagrell et al., 1980; Ley et al., 1988). To which extent this influences the viscosity is still unclear. Inclusion of these aspects in the model requires simultaneous measurement of changes in arteriolar diameter and hematocrit, which is difficult in skeletal muscle preparations. Besides, it is unknown whether there is a good relation between relative hematocrit and viscosity. In conclusion the effective diameter of a microvessel, showing vasomotion, provides direct insight into the vascular resistance or flow carrying capacity of that vessel. The effective diameter should be calculated directly from the actual arteriolar diameter tracings, to take into account all irregularities in the vasomotion pattern.

\subsection{Summary}

The mean resistance of arterioles exhibiting rhythmic changes in diameter (vasomotion) depends on the mean vascular diameter and the amplitude and shape of the va- 
somotion pattern. The effective diameter, defined as the diameter of a tube with constant diameter and the same vascular resistance as the vessel showing vasomotion, was calculated using Poiseuille's law. The effective diameter was used to compare the results of model calculations of square wave, sinusoidal, and triangular vasomotion patterns with those obtained from rabbit tenuissimus muscle arterioles. Due to the variability of the actual vasomotion waveforms, approximation of the effective diameter using the mean diameter, the relative vasomotion amplitude and an assumed waveform leads to erroneus results. Therefore, effective diameter should be calculated directly from the actual arteriolar diameter tracings, to take into account all irregularities in the vasomotion pattern.

\subsection{Appendix}

Equations of waveforms shown in figure 5.2.

Square wave vasomotion (figure 5.2A, 5.2D):

$$
\begin{array}{ll}
D(t)=D+0.5 A, & \text { if } 0<t<(b+a) T \\
D(t)=D-0.5 A, & \text { if }(b+a) T<t<(1+a) T \\
0 \leq A \leq 2 D ; \quad 0 \leq b \leq 1 ; \quad a \geq 0 &
\end{array}
$$

Triangular shape of vasomotion (figure $5.2 \mathrm{~B}, 5.2 \mathrm{E}$ ):

$$
\begin{array}{ll}
D(t)=D-0.5 A+\frac{A}{c T} t, & \text { if } 0 \leq t \leq c T \\
D(t)=D+0.5 A, & \text { if } c T \leq t \leq(a+c) T \\
D(t)=D+0.5 A-\frac{A}{(1-c) T}(t \cdot(a+c) T), & \text { if }(a+c) T \leq t \leq T \\
0 \leq A \leq 2 D ; \quad 0 \leq c \leq T ; \quad a \geq 0 &
\end{array}
$$


Sinusoidal shape of vasomotion (figure 5.2C, 5.2F):

$$
\begin{array}{ll}
D(t)=D+0.5 A \sin (t), & \text { if } 0 \leq t \leq 0.25 T \\
D(t)=D+0.5 A, & \text { if } 0.25 T \leq t \leq(0.25+a) T \\
D(t)=D+0.5 A \sin (t-a T), & \text { if }(0.25+a) T \leq t \leq(1+a) T \\
T=2 \pi &
\end{array}
$$




\section{CHANGES IN VASOMOTION PATTERN AND LOCAL ARTERIOLAR RESISTANCE DURING STEPWISE PRESSURE REDUCTION}

\subsection{Introduction}

Small arterioles play an important role in skeletal muscle blood flow regulation (Johnson, 1980). These vessels generally exhibit pronounced vasomotion (Tangelder et al., 1984; Slaaf et al., 1987 ; Meyer et al., 1988 ), resulting in a continuously fluctuating local vascular resistance. Since amplitude (Funket al., 1983) and waveform (chapter 5) of vasomotion contribute to the mean vascular resistance, and these parameters change during stepwise arterial pressure reduction (Bouskela and Wiederhielm, 1979; Johnson, 1980; Burrows and Johnson, 1981; Oude Vrielink et al., 1988 ${ }^{1}$ ), vasomotion may play a role in the regulation of blood flow under these circumstances. The observation that gradual pressure reduction did not influence vasomotion amplitude and cycle length of rabbit tenuissimus muscle arterioles (Slaaf et al, 1987 $7^{\text {a }}$ ) is not necessarily in disagreement with this idea. In these experiments the time course of pressure reduction may have been too fast to allow the vasculature to adapt and, hence, to observe changes in the vasomotion pattern.

It was the aim of the present study to investigate the effect of stepwise arterial pressure reduction on vasomotion cycle length and amplitude, and the consequences of these changes, if any, for local arteriolar resistance and, hence, skeletal muscle perfusion. To obtain more insight into the mechanisms of vasomotion control, the relations between the vasomotion parameters on the one hand and arteriolar diameter, blood flow and wall shear rate on the other were assessed in the control situation and during stepwise pressure reduction. The experiments were performed on transwerse arterioles

1 These data have been published in abstract-form in: Oude Vrielink et al., Europ. J. Physiol. (Pflüg. Arch.) 410: S31, 1987. 
and their first order side branches of the rabbit tenuissimus muscle with the use of intravital microscopy.

\subsection{Materials and methods}

Animal preparation: the experiments were performed on the tenuissimus muscle of 10 young (5-6 weeks) mixed breed rabbits of either sex, ranging in weight between 700 and $1000 \mathrm{~g}$. Anesthesia was induced by injecting $5 \mathrm{mg} / \mathrm{kg}$ diazepam i.m.. After 30 minutes, $4.5 \mathrm{ml} / \mathrm{kg}$ of a solution of urethane (20\% in saline) was administered intravenously in about 4 minutes. If necessary, additional doses of urethane (generally less than $0.3 \mathrm{ml}$ per hour) were given during the experiment.

To facilitate breathing, the trachea was cannulated. Arterial pressures were recorded via catheters in the left common carotid artery $\left(\mathrm{P}_{\mathrm{car}}\right)$ and the right femoral artery $\left(P_{\text {fem }}\right)$, using CTC CP-01 pressure transducers. These catheters were also used for continuous infusion of physiological saline $(2.5 \mathrm{~m} / \mathrm{h}$ through each catheter) to compensate for respiratory fluid losses.

Pressure in the arteries supplying the hind limbs could be reduced by inflating a cuff placed retro-peritoneally around the descending aorta distal to the renal arteries. The pressure in the right femoral artery could be set at any level between control pressure and $10 \mathrm{mmHg}$ by means of a servo-system, as described in detail before (Prinzen et al., 1987).

The preparation of the tenuissimus muscle of the left hind limb has been described elsewhere (Reneman et al., 1980). In short, after making a skin incision and cutting the subcutaneous connective tissue, the muscle was exposed by reflection of the biceps femoris muscle. From its first exposure on the muscle was suffused with physiological saline. To allow transillumination of the muscle an incision was made in the connective tissue posterior to the tenuissimus muscle. Subsequently, the hind limb was placed in a box that could be sealed to control the gas environment. After a light pipe for transillumination was positioned underneath the tenuissinus muscle (Reneman et al., 1980), the box was mounted on the stage of the microscope. Suffusion was performed with a Krebs solution (composition in $\mathrm{mM}$ : $\mathrm{NaHCO}_{3}, 25 ; \mathrm{KH}_{2} \mathrm{PO}_{4}, 1.2 ; \mathrm{KCl}, 4.8 ; \mathrm{CaCl}_{2}, 2.5$; $\mathrm{MgSO}_{4}, 1.2 ; \mathrm{NaCl}, 118.4$ ) saturated with $95 \% \mathrm{~N}_{2}$ and $5 \% \mathrm{CO}_{2}$ (actual pH: $7.34 \pm 0.02$ ). The same gals mixture was led through the box. The preparation was allowed to stabilize for 30 minutes.

Microscopic system: the experiments were performed with a Leitz intravital microscope which was adapted to telescopic imaging (Slaaf et al., 1982). Leitz salt water immersion objectives ( $\mathrm{SW} 25 \mathrm{x}$, numerical aperture $=0.6$ or SW 50x, numerical aperture $=1.0$ ) were used. Images were displayed on a monitor (Siemens) through a TV-camera (Bosch Ultricon 4532, 1 inch) and recorded on video tape (Sony Betamax) for off-line 
analysis. Total optical magnification at the front plane of the TV-camera was 51.6 (SW 25x) or 103.2 (SW 50x). Transillumination of the muscle was performed with a mercury $\operatorname{arc}(100 \mathrm{~W})$ and a condenser system positioned in front of the light pipe (Reneman $e t$ al., 1980). Neutral density filters in the illuminating pathway were used to reduce the light intensity in the muscle to the lowest level still yielding a good image on the monitor.

Arteriolar blood cell velocity $\left(\mathrm{V}_{\mathrm{bc}}\right)$ was measured on-line using the dual-slit photometric technique (Wayland and Johnson, 1967). To reduce the light intensity, a neutral density filter of $50 \%$ transmittance was interposed between the dual-slit light rods and the video camera, because good velocity recordings could be obtained only at relatively high light intensities.

The signals of $\mathrm{P}_{\mathrm{car}}, \mathrm{P}_{\mathrm{fem}}$ and $\mathrm{V}_{\mathrm{bc}}$ were displayed on a physiological recorder (Schwarzer) and stored on video tape simultaneously with the microscopic images via a homebuilt pulse-code-modulation system. This system, which adds a maximum of 8 analog signals to the normal video image, is similar to the system described by Elmore and Johnson (1982) and allows the off-line synchronization of arteriolar diameter measurements and the variables measured on-line.

Vascular pattern: a central artery and vein run parallel to the muscle fibers in the thickest part of the muscle. Transverse arterioles (TAs) branch from the central artery, dichotomize one or more times and frequently form arcading connections with adjacent TAs (chapter 4). Most TAs ultimately run into the anterior fascia, where they form arteriolar-venular shunts. The first order side branches (FOS) of these TAs divide several times before ending in true capillaries, which run parallel to the muscle fibers. The FOS are considered to be functionally the terminal arterioles.

Experimental procedure: at the beginning of an experiment a TA was selected that clearly showed vasomotion and that could be observed in focus over a sufficient length (usually a distance of more than $1000 \mu \mathrm{m}$ between the most proximal part of the TA and the muscle edge). A drawing was made of this TA and 3-8 measuring sites were selected where FOS branched from the TA. The measuring sites were chosen along the whole length of the TA.

Each measuring site was recorded during a control period of $1-2$ minutes, while $\mathbf{P}_{\text {car }}$, $P_{f e m}$ and $V_{b c}$ were registered simultaneously. Subsequently, $P_{f e m}$, as measured in the contralateral limb, was reduced by lowering the reference level of the feed-back occlusion system. The pressure adjustment usually took less than 10 seconds. After a stabilization period of 0.5 to $\mathbb{1}$ minute, the first measuring site was recorded and the various variables were measured again during 1-2 minutes. Pressure reduction was performed in steps of approximately $10 \mathrm{mmHg}$. After release of the aortic occlusion, a stabilization period of approximately $5 \mathrm{~min}$ followed before the procedure was repeated at the next measuring site.

After measuring the last site and perfusion pressure had been restored, the muscle was suffused with a Krebs solution with adenosine (ADO; $10^{-3} \mathrm{M}$ final concentration) to 
induce maximal vasodilation. To assess the dilating capacity, all measuring sites were recorded again for approximately 1 minute at least five minutes after the onset of this suffusion.

Off-line anclysis: the instantaneous arteriolar diameter (D) of TAs and FOS were measured by replaying the videotapes at reduced speed (20\% of control), using a homebuilt image shearing device similar to the one described by Intaglietta and Tompkins (1973). The calibrated output signals of the shearing device and the recorded signals of $\mathrm{P}_{\mathrm{car}}, \mathrm{P}_{\text {ferm }}$ and $\mathrm{V}_{\mathrm{bc}}$ were digitized, using a 4-channel analog-digital converter ( 12 bit), and were stored on floppy disk (Digital Equipment Corporation, MINC-11 computer). A maximum of 2.5 minutes (real-time) of the videotape could be stored in 1 data file (sampling frequency: $10 \mathrm{~Hz}$ ). All data on floppy disk were obtained as an instantaneous function of time. Blood flow (Q) was calculated from the instantaneous blood cell velocity and diameter data using the following equation:

$$
Q=\frac{\pi}{4} D^{2} V_{b c} / B
$$

where $\beta$ is a proportionality factor to transform $V_{b c}$ to mean blood velocity. It ranges between 1.33 and 1.6 depending on the ratio between effective sensor width and the instantaneous arteriolar diameter. For each diameter value, this factor was computed according to Pittman and Ellsworth (1986). Reduced velocity (U), as a measure of wall shear rate, was calculated from $U=V_{b c} / \beta D$. Mean values of $P_{c a r}, P_{f e m}, V_{b c}, D, U$ and $Q$ were computed for each observation period. Heart rate was derived from $P_{\text {car. }}$.

Vasomotion parameters (see figure 6.2) were derived from the diameter tracings of both TAs and FOS during each observation period. For each vasomotion cycle, cycle length, (CL, being the time difference between two consecutive cycles) and amplitude ( $A$, being the difference between the maximal and minimal diameter) were assessed. Mean values for each observation period were computed. The number of cycles analyzed during one period was generally more than 7. Periods of suppressed vasomotion activity were discarded. The relative vasomotion amplitude (RA) was calculated by dividing $A$ by the arythmic mean vascular diameter $(\bar{D})$ of the observation period. The most proximal part of a FOS, i.e. the area where almost complete closure of the vascular lumen occurs during vasomotion, could be observed in sharp focus simultaneously with the TA in 5 out of 10 experiments. Only these FOS were used for analysis of $A, R A$ and $\tilde{D}$. CL, however, appeared to be constant over the whole active length of a FOS. Therefore, vasomotion tracings of all FOS, including those in focus more distally, were used for analysis of CL.

In TAs and FOS in focus proximally, the maximal diameter during vasomotion ( $\mathrm{D}_{\max }$; see figure 6.2) was taken as a measure of the degree of stretching of the arteriolar wall. The diameter tracings of all FOS were used to assess the mean delay time between the onset of each vasomotion cycle in the FOS and that in the adjacent segments of the 
TAs.

For each of the measuring sites its distance to the muscle border was measured from the maps of the TAs to verify whether changes in the vasomotion parameters were related to the relative position of the measuring site in the vascular tree.

Calculation of effective vascular diameter: the effective vascular diameter ( $D_{\text {eff }}$ ) is the diameter that a vessel without vasomotion would need to carry the same blood flow as the vessel where vasomotion is present, assuming that the pressure gradient over the vessel segment is the same for both situations. $D_{\text {eff }}$ was calculated using the relation:

$$
D_{\text {eff }}^{4}=\int_{0}^{T} D^{4}(t) d t / T
$$

where $T=$ duration of an integer number of vasomotion cycles (see appendix; chapter 5).

In TAs and in the group of FOS where the most proximal area could be observed in

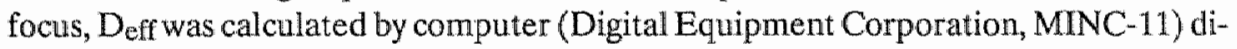
rectly from the actual diameter tracings, using the digitized values of these tracings to solve equation 1.

Data processing and statistics: variables have been expressed as normalized to their control value if the normalization procedure led to a reduction in the variation of the data points. Correlations between the various parameters are displayed as plots of the individual data points, and described by the lowest order (linear or polynomial) best-fit. In some of these plots, different symbols are used which refer to different ranges of a third variable, indicated at the top of each graph.

Because no systematic differences could be detected between the values as measured at the various sites along the vascular tree, all data were pooled. The data are presented as median and range. Differences between the groups of pooled data were tested using a sign test. In all tests, a $5 \%$ level of significance was used.

\subsection{Results}

\section{General observations}

Vasomotion was a common observation along all TAs. The amplitude, however, varied locally and was most pronounced at bifurcations and at the sites where the FOS branched from the parent arteriole. Vasomotion was periodically suppressed (see figure 6.1). These periods of suppression occasionally occurred simultaneously in TAs 


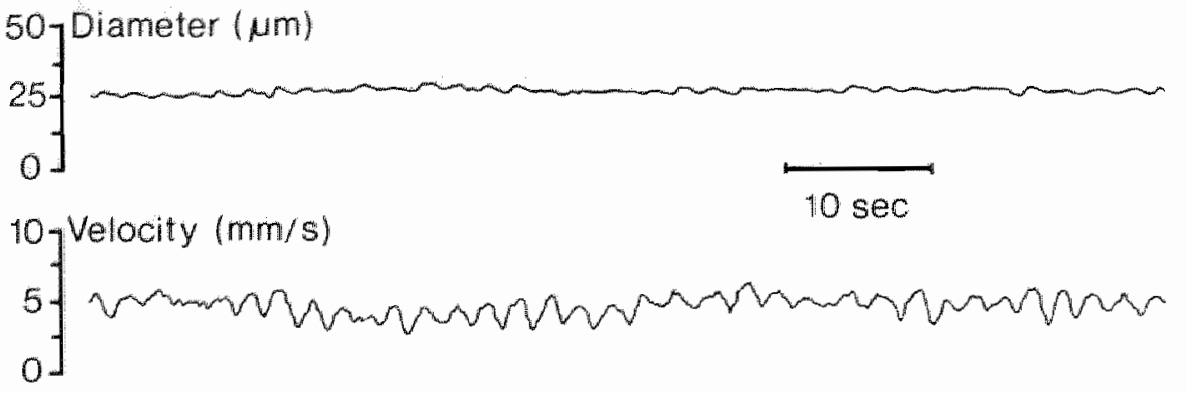

time-scale

FIGLRE 6.I: Example of simulaneous recordings of diamever (upper tracing) and blood cell velocity (lower tracing) in time in a transwerse arteriole.

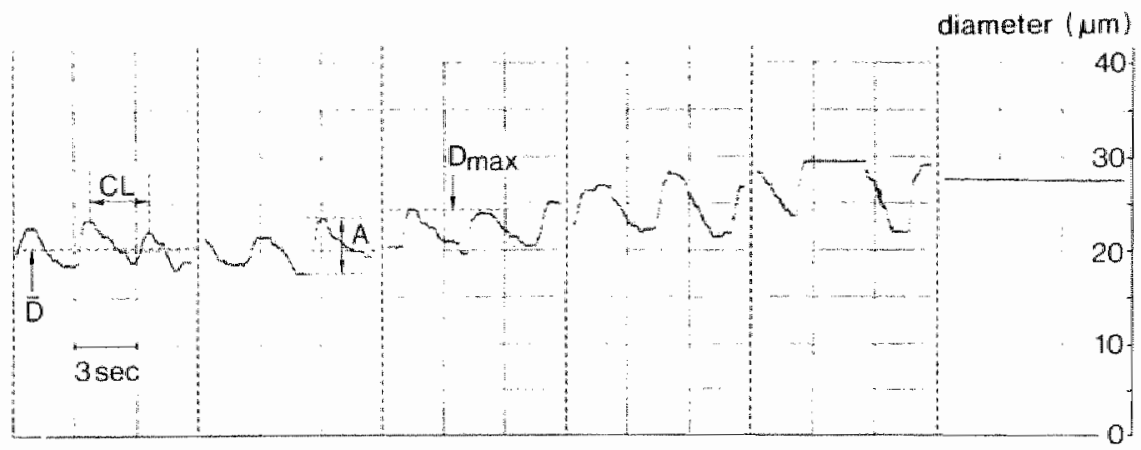

mean arterial pressure

$(\mathrm{mm} H \mathrm{lg})$

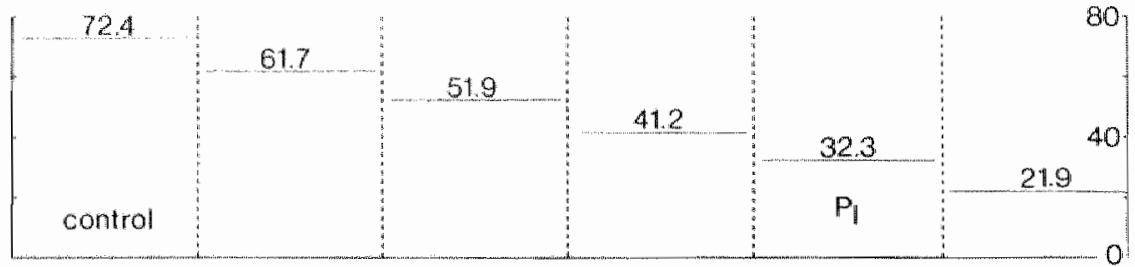

FIGURE 6.2: Dianter tracings, as recorded at one site in a transverse arteriole (upper panei), at different levels of femoral artery pressure ( $P_{\text {femi }}$ lower panel). Vasomotion cycle length $(C L)$, wasomotion amplitude (A) and mean maximal diameter during vasomotion $\left(D_{\mathrm{max}}\right)$ are illustrated. $P_{1}=$ lowest pressure at which wasomotion is still present. 
and FOS, but also independently in either type of the vessel. When not suppressed, vasomotion cycles started synchronously in TAs and FOS. Blood cell velocity and blood flow in TAs showed rhythmic variations with cycle lengths similar to those of the diameter variations, but generally with a more regular pattern (figure 6.1).

Stepwise reduction of arterial pressure resulted in an increase in $\bar{D}, D_{\text {eff, }} \mathrm{Cl}$ and $\mathrm{A}$ in both TAs and FOS, until vasomotion abruptly disappeared. Carotid artery pressure slightly, but significantly increased from a median value of $79.4 \mathrm{mmHg}$ during control (range: $70.3-94.8 \mathrm{mmHg}$ ) to a median value of $84.4 \mathrm{mmHg}$ (range: $69.3-102.0 \mathrm{mmHg}$ ) at the lowest pressure attained. Heart rate did not change during pressure reduction. A set of recordings, showing the typical changes in vasomotion pattern with reduction of perfusion pressure in a transverse arteriolar segment, is presented in figure 6.2. The changes in the pooled data of all parameters during perfusion pressure reduction are shown in figure 6.3 for TAs (upper panel) and FOS (lower panel). Although considerable variations in the changes of all measured parameters were observed from arteriole to arteriole in both TAs and FOS, pressure reduction resulted in an over-all increase in CL, A and RA in TAs concomitant with an increase in Deff, and a decrease in $Q$ and U. Autoregulation of blood flow was observed in 18 out of 25 vascular segments; in some segments superregulation, i.e. an increase in local blood flow in response to pressure reduction, was observed. In FOS, changes in CL and A were comparable to the changes in TAs (figure 6.3, lower panel). RA decreased slightly, due to a pronounced increase in mean vascular diameter. In the cases in which a TA and a FOS could be observed simultaneously, vasomotion occurred synchronously during the whole range of pressure reductions. For the whole populations of TAs and FOS, the values of the various parameters in the control situation and at the lowest pressure level, at which vasomotion was still present, are summarized in table 6.1. Note the small difference between $\overline{\mathrm{D}}$ and $\mathrm{D}_{\text {eff }}$ in TAs, indicating a minor contribution of vasomotion in TAs to mean vascular resistance. Adenosine application further dilated TAs and FOS to $149 \%$ (median; range: $114-220 \%$ ) and $342 \%$ (range: $237-472 \%$ ) of the control values of $D_{\text {eff, }}$ respectively. During pressure reduction and adenosine application, $Q$ changed similarly at the most proximal vascular segments and the most distal ones: no redistribution of blood flow between muscle and connective tissue was found.

\section{Changes in vasomotion cycle length}

A plot of all individual data points of normalized cycle length as a function of normalized perfusion pressure in TAs is shown in figure 6.4. The data were best fitted by a second order polynomial. The fit indicates that $\mathrm{Cl}$ increases progressively with decreasing perfusion pressure. The data presented in figure 6.4 also suggest a relation between $D_{\text {eff }}$ and $C L$, but this was less distinct than the relation shown in figure 6.4. The correlation between CL and Q was comparable to the one shown in figure 6.4. In figure 6.5 the individual data points of normalized CL are plotted as a function of normalized U. Again, the second order polynomial fit indicates that CL increases progressively with decreasing $\mathrm{U}$. 

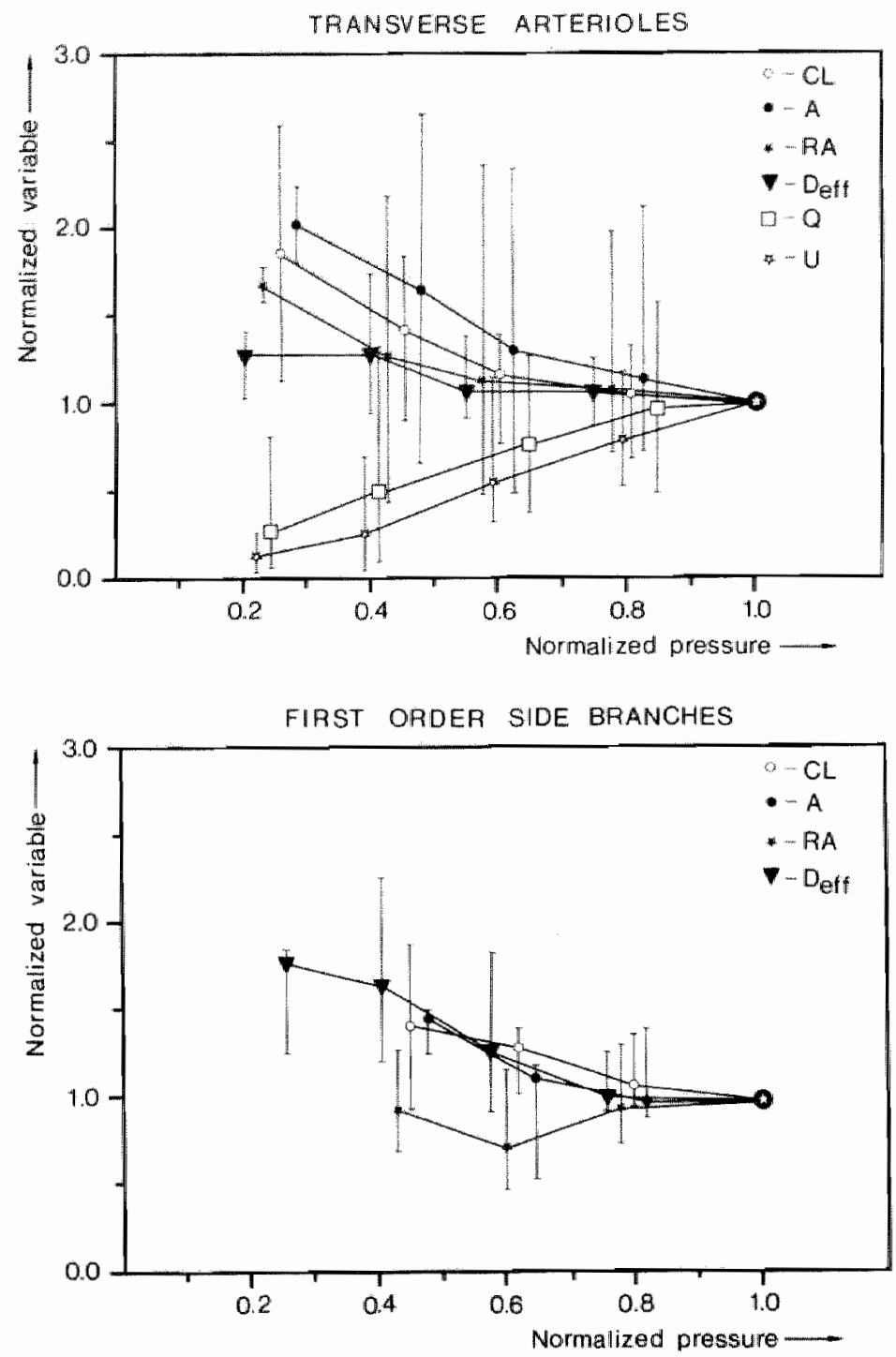

FIGURE 6.3: Changes in vasomotion cycle length (CL), amplitude (A), relative amplitude (RA), effective vascular diameter $\left(D_{\text {eff }}\right)$, blood flow $(Q)$ ) and reduced velocity ( $U$ ), nommalized to control, with reduction of arterial pressure, normalized to control, for TAs (upper panel) and FOS (lower panel). $Q$ and $U$ were not meastured in FOS. Symbols indicate median walues in both wertical and horizontal direction. For the sake of clarity, ontly $C L$ is plotted at the proper position on the abscissa. Only in vertical direction, ranges are indicated by bars. 


\begin{tabular}{|c|c|c|c|c|c|c|c|c|}
\hline 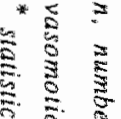 & & $\begin{array}{l}\vec{B} \\
\ddot{u}\end{array}$ & & & 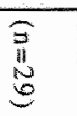 & & & \multirow{2}{*}{ 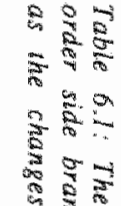 } \\
\hline $\begin{array}{l}8 \\
\frac{3}{5}\end{array}$ & $\frac{D}{3}$ & 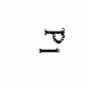 & 0 & $\frac{2}{a^{2}}$ & $\square$ & ? & & \\
\hline $\begin{array}{l}\frac{8}{5} \\
0 \\
0 \\
0 \\
0 \\
0 \\
0 \\
0 \\
0\end{array}$ & 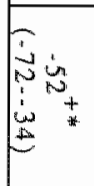 & $\begin{array}{l}\infty \\
\infty \\
i \\
i \\
\infty\end{array}$ & $\begin{array}{l}\operatorname{son}_{3} \\
-8 \\
\infty \\
\infty \\
\infty\end{array}$ & $\begin{array}{l}2 \\
i n \\
i \\
0 \\
0\end{array}$ & $\begin{array}{l}3 \\
\infty \\
0 \\
0 \\
0 \\
0 \\
0 \\
0 \\
0\end{array}$ & $\begin{array}{l}\text { wa } \\
0 \\
4 \\
\infty \\
\infty \\
\infty \\
\infty \\
j \\
0\end{array}$ & $\begin{array}{l}3 \\
3 \\
3 \\
3 \\
0\end{array}$ & 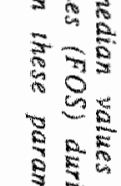 \\
\hline 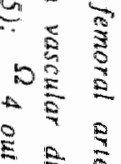 & 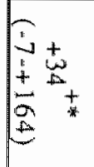 & $\begin{array}{l}6 \\
u_{10} \omega \\
\infty \\
\infty \\
0\end{array}$ & 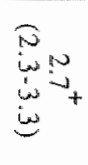 & 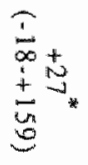 & $\begin{array}{l}\widehat{\infty} \\
\infty \\
\infty \\
\infty \\
\infty \\
\infty\end{array}$ & 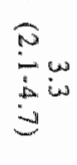 & $\overbrace{\infty} \theta$ & 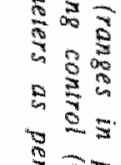 \\
\hline $\begin{array}{lll}8 & 0 & 2 \\
4 & 0 & 0 \\
0 & 0 & 5 \\
0 & 0 & 5 \\
0 & 0 & 5 \\
5 & 0 & 5\end{array}$ & 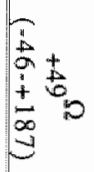 & 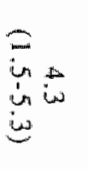 & $\begin{array}{l}0 \\
\ln _{0} \\
\omega_{\infty} \infty \\
\infty\end{array}$ & 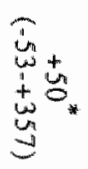 & $\begin{array}{l}0 \\
0 \\
\dot{1} \\
0 \\
0\end{array}$ & $\begin{array}{l}= \\
+\infty \\
+\infty \\
\infty\end{array}$ & $\widetilde{E}$ & 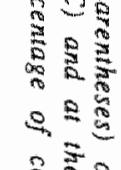 \\
\hline 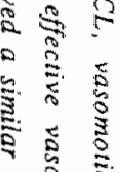 & 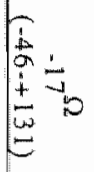 & $\begin{array}{l}\omega_{1} \\
w^{\prime} u \\
\infty \\
\infty\end{array}$ & $\begin{array}{l}0 \\
5 \\
5\end{array}$ & 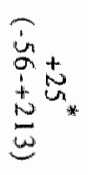 & $\vec{j}=$ & 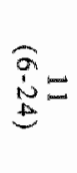 & $\mathrm{s}^{2}$ & 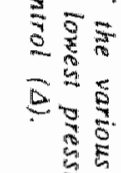 \\
\hline 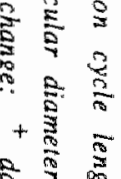 & 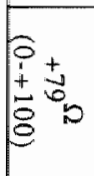 & $\begin{array}{l}5 \\
i n d \\
6 \\
0\end{array}$ & $\begin{array}{l}\omega \\
i=t \\
b i n \\
i \\
\omega\end{array}$ & 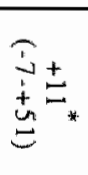 & $\begin{array}{l}0 \\
\omega \\
\infty \\
0 \\
0 \\
0 \\
0 \\
0\end{array}$ & $\begin{array}{l}\exists \\
\text { in } \\
\text { in } \\
0 \\
0 \\
0\end{array}$ & $\widehat{E} \theta$ & : \\
\hline $\begin{array}{ll}0 & 5 \\
0 & 3 \\
0 & \\
0 & 8 \\
8 & 8 \\
3 & 3\end{array}$ & 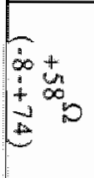 & $\begin{array}{l}\infty \\
\infty \\
0 \\
0 \\
0\end{array}$ & 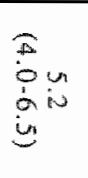 & $\underbrace{\infty}_{1}+\frac{1}{+\infty}$ & $\begin{array}{l}\underbrace{}_{W} \\
\infty \\
\infty \\
w \\
6 \\
0 \\
0\end{array}$ & 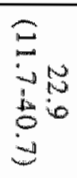 & $\begin{array}{l}E \\
\Xi\end{array}$ & $\begin{array}{l}5 \\
3 \\
3 \\
0 .\end{array}$ \\
\hline 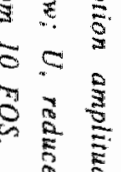 & " & ' & " & $\begin{array}{l}3 \\
4 \\
w \\
4 \\
4 \\
+\infty \\
0 \\
0\end{array}$ & 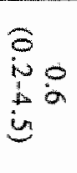 & $\begin{array}{l}0 \\
\dot{1} 0 \\
\omega_{0} \\
0 \\
0\end{array}$ & $\sum_{\infty} \infty$ & 5 \\
\hline $\begin{array}{l}\frac{2}{2} \\
\frac{2}{2} \\
3 \\
3\end{array}$ & 1 & 4 & " & 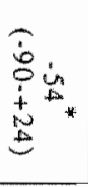 & $\begin{array}{l}0 \\
\infty \\
1 \\
0 \\
\infty \\
0\end{array}$ & $\begin{array}{l}\omega \\
\omega \\
0 \\
\omega \\
\omega \\
0 \\
0 \\
0 \\
0\end{array}$ & $\stackrel{-\infty}{-\infty}$ & 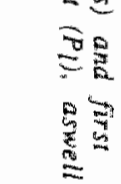 \\
\hline
\end{tabular}




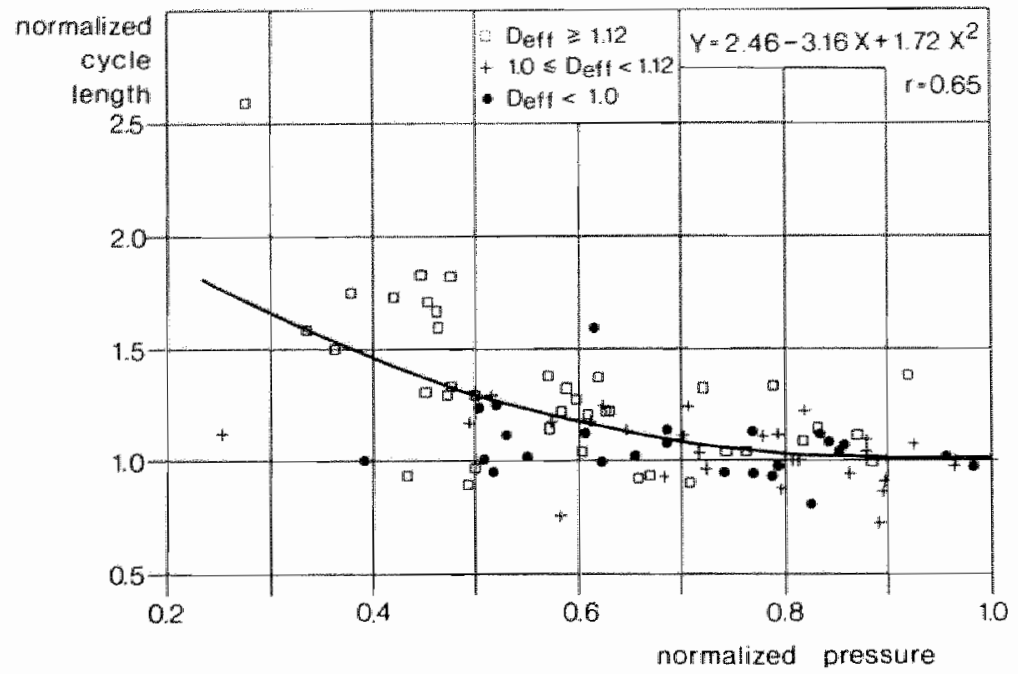

FIGURE 6.4 : Scatter plot of wasomotion cycle length normalized to controt, as a function of arterial pressure, norrmalized to control, for TAs. Different symbols refer to different ranges of effective diameter ( $D_{\text {ent }}$ ), nomalized to control, as indicated at the top. $A$ second order best-fit of the data is shown. $r=$ comelation coefficient.

In the FOS $V_{b c}$ could not be measured accurately due to the frequently occurring complete cessation of flow in these vessels resulting in hampering of proper functioning of the dual-slit cross correlation method. Therefore, CL could be related to perfusion pressure only. The changes were similar to those in TAs.

\section{Changes in vasomotion amplitude}

In TAs, normalized vasomotion amplitude showed a relatively poor correlation with normalized perfusion pressure and normalized $\mathbb{D}_{\text {eff }}$ (figure 6.6). $\mathrm{Q}$ and $\mathrm{U}$, however, showed better correlations with A, U correlating the best (figure 6.7). A second order polynomial was used to fit the data. The changes in vasomotion amplitude did not correlate to the changes in $\mathrm{CL}_{4}$, nor to changes in $\mathrm{D}_{\text {max }}$.

In FOS, amplitude increased significantly with decreasing perfusion pressure, but no relation with the increase in $D_{\mathrm{eff}}$ was found. $D_{\max }$ increased from $6.3 \mu \mathrm{m}$ (median; range: $4.9-6.9 \mu \mathrm{m}$ ) during control to $9.2 \mu \mathrm{m}$ (median; range: $6.0-10.6 \mu \mathrm{m}$ ) at the lowest pressure at which vasomotion was still present. As in TAs no correlation between $A$ and $\mathrm{CL}$, nor between $\mathrm{A}$ and $\mathrm{D}_{\max }$ was found. 


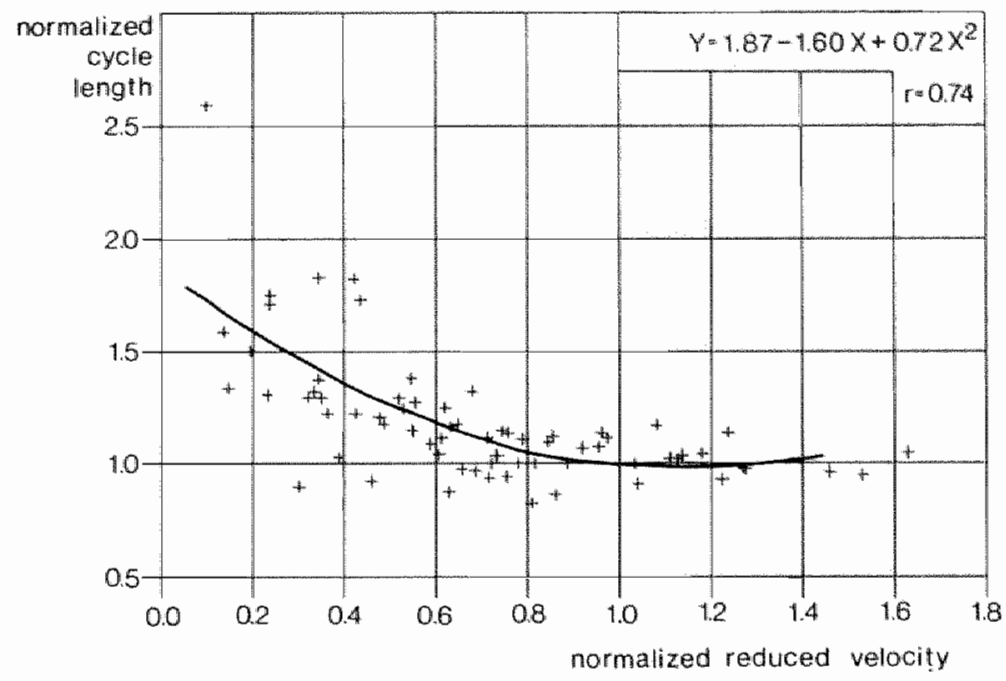

FIGURE 6.5: Scatter plot of vasomotion cycle length nomialized to control, as a function of reduced velocity, normalized to control, for TAs. A second order best-fit of the data is shown. $r=$ correlation coefficient.

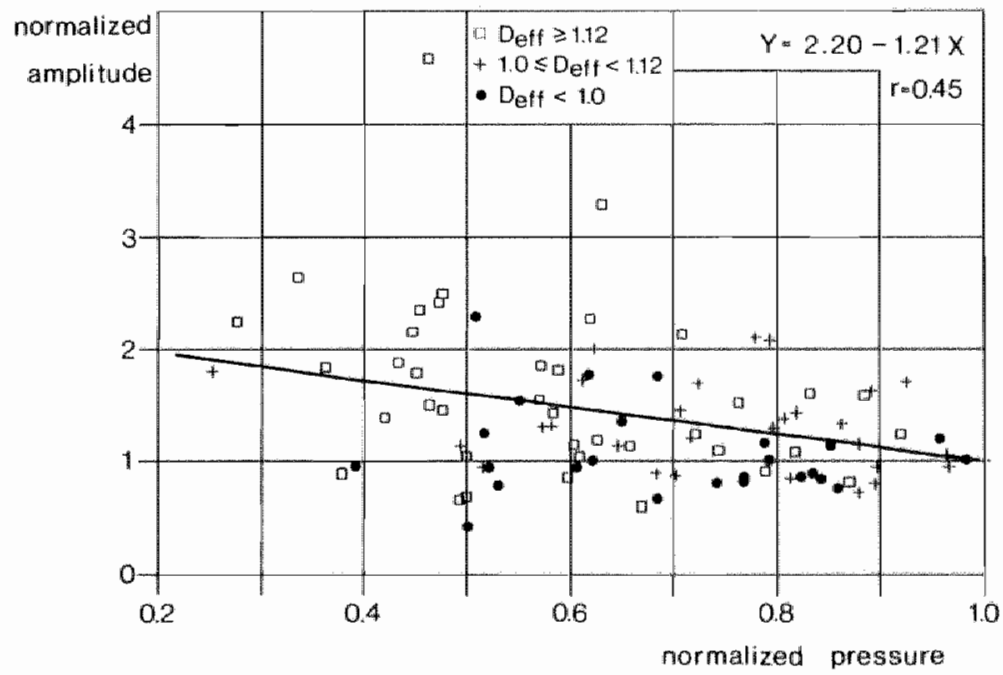

FIGURE 6.6: Scatter plot of vasomotion amplitude, nomalized to control, as a function of arterial pressure, normalized to control, for TAs. Different symbols refer to different ranges of effective diameter ( $D$ eft, normalized to control, as indicated at the top. A linear best-fit of the data and its correlation coefficient ( $r$ ) is shown. 


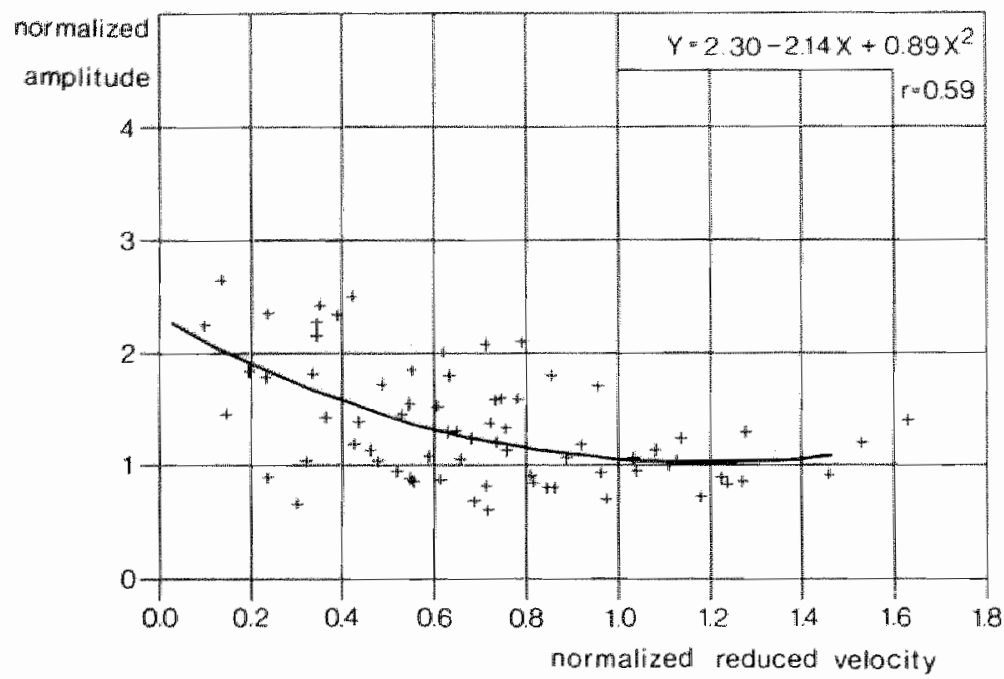

FIGURE 6.7 : Scatter plot of vasomotion anplitude, normalized ro cantrol, as a function of reduced velocity, nomalized to control, for TAs. A second order best-fit of the dat a is shown. $t=$ correlation coefficient.

\subsection{Discussion}

The findings in the present study indicate that the contribution of vasomotion to mean local vascular resistance is limited in TAs, but considerable in FOS. Arterial pressure reduction results in similar changes in vasomotion cycle length and amplitude in TAs and FOS, although considerable variation between the various arterioles is observed. These changes show only limited correlations with blood flow, wall shear rate and effective vascular diameter, indicating that it is unlikely that only one of these variables is responsible for the changes in the vasomotion parameters.

The conclusion that vasomotion in TAs contributes to mean local vascular resistance only to a limited extent is based on the finding that the difference between mean arteriolar diameter and effective diameter is relatively small (table 6.1). Since in the present study only the most active areas of a TA were selected, i.e. the sites where FOS branch from their parent vessels, this conclusion holds for TAs in general "In FOS, however, vasomotion has a relevant contribution to the local vascular resistance, since vasomotion in these arterioles dominates capillary perfusion. Moreover, effective diameter and mean diameter differ substantially in these vessels (table 6.1). Although the difference between $5.2 \mu \mathrm{m}$ and $4.5 \mu \mathrm{m}$ seems to be small, it means a difference in flow carrying capacity of $78 \%$. It is likely that the influence of vasomotion in the FOS 
is even underestimated. The diameter tracings of FOS never show complete lumen closure, despite the observation that capillary flow stops periodically. This discrepancy is probably caused by the problems encountered in the identification of the inner arterialar wall during closure of the lumen due to folding of the inner surface of the arterioles (Greensmith and Duling, 1984). This leads to overestimation of the mean arteriolar diameter, as compared to the effective diameter.

Blood flow and blood cell velocity in TAs show thythmic variations similar and closeJy related in time to the pattern of vasomotion in TAs and FOS. Since the fuctuations in velocity and flow were also observed during the periods of suppressed activity in the TAs (figure 6.1), these fluctuations cannot be explained by vasomotion in the TAs. Therefore, the flow variations in TAs are likely to be completely dominated by the vasomotion in the FOS. This idea is supported by the observations that vasomotion occurs synchronously in TAs and FOS (present chapter) and in adjacent FOS (Meyer et al., $1987^{\mathrm{a}}$ ).

The changes in blood flow in TAs when arterial pressure is reduced, vary greatly between the different arterioles, showing autoregulation in some, but not in others. This has also been observed in rat cremaster muscle (Morff et al., 1983) and cat mesentery (Burrows and Johnson, 1981). Pooling the data, however, demonstrates the presence of autoregulation. If the median values are considered to represent blood flow through the whole muscle, one may conclude that whole muscle blood flow rather than flow through individual vessels is regulated (Johnson, 1986). No redistribution of blood flow between muscle and connective tissue was observed when reducing arterial pressure, a finding in agreement with previous observations of Lindbom and colleagues (1984, $1986)$ in the same muscle preparation. This probably is a consequence of the low metabolic state of the resting muscle: the applied periods of reduced flow are probably too short to cause accumulation of metabolites.

The over-all increase in vasomotion cycle length in TAs and FOS when pressure is stepwise reduced, as observed in this study, is in accordance with findings in previous investigations using the same protocol (Bouskela and Wiederhielm, 1979; Johnson, 1980; Burrows and Johnson, 1981). These results seem to contradict the observations in recent studies in our own laboratory (Slaaf $e t a l, 1987^{\mathrm{a}}$ ) and elsewhere (Meyer $e t$ al, $\left.1988^{\mathrm{a}}\right)$, but this is not necessarily the case. Slaaf and colleagues $\left(1987^{\mathrm{a}}\right)$ did not observe changes in vasomotion cycle length during initially stepwise pressure reduction followed by gradual reduction of pressure in the lower pressure range until vasomotion suddenly disappeared. Because the present study demonstrates that the most pronounced changes in the vasomotion parameters occur only in the lower pressure range, it is likely that the gradual reduction of pressure in this range was too fast to observe changes in the vasomotion pattern in their experiments. Meyer and co-workers (1988 also reported that vasomotion cycle length remained constant during pressure reduction. Their conclusion, however, is based on only one single pressure step of $10 \mathrm{~mm} / \mathrm{Hg}$ below control, an intervention which does not necessarily lead to vasomotion changes because it does not result in changes in effective arteriolar diameter and local blood flow (present results), and in micropressure (Burrows and Johnson, 1981; Slaaf et al., 
$\left.1987^{b}\right)$

The present results show that in vasomotion amplitude increases during arterial pressure reduction, whereas in the study of Meyer and co-workers $\left(1988^{\mathrm{a}}\right)$ a decrease in vasomotion amplitude was observed. Their data included vessel segments in which vasomotion had already ceased, i.e. vasomotion amplitude had become zero. In the present study, however, vessel segments in which vasomotion had ceased were excluded. Including these data would also have led to a decrease in vasomotion amplitude in both TAs and FOS. It might be that the increase in amplitude, as observed in the present study, is the result of a decrease in wall tension during pressure reduction (Johnson, 1980; Burrows and Johnson, 1981). This decrease, which implies a diminished force opposing the smooth muscle cells, allows more pronounced contractions and, hence, might directly lead to an increase in wasomotion amplitude.

The findings in this study cannot be conclusive about the mechanism involved in the control of vasomotion cycle length and amplitude. More than one mechanism might be involved, since the changes in cycle length and amplitude do not correlate. Vasomotion control purely by stretching of the arteriolar wall, as proposed by Folkow (1964), is unlikely. Folkow's hypothesis predicts an increase in vasomotion cycle length and a decrease in amplitude when transmural pressure is reduced due to decreased stretching of the vessel wall. In the present study, however, pressure reduction results in increased wall stretch, because the maximal diameter during vasomotion increases in TAs and FOS. Therefore, Folkow's hypothesis does not adequately explain the increase in vasomotion cycle length and amplitude, as observed in the present study. The correlations found between the changes in vasomotion parameters and blood flow indicate that metabolic factors might play a role in vasomotion control. Since the vasomotion parameters also correlate with reduced velocity, which is a measure of wall shear rate, shear forces exerted on the endothelial cells might play a role (Tesfamariam and Halpern, 1987).

In conclusion, unlike in TAs vasomotion in FOS contributes significantly to the mean local vascular resistance. Arterial pressure reduction results in an increase in vasomotion cycle length and amplitude. The mechanism involved in the changes in these vasomotion parameters is as yet unclear.

\subsection{Summary}

Changes in vasomotion parameters and their consequences for local vascular resistance were studied in transverse arterioles (TAs) and their first order side branches (FOS) in the tenuissimus muscle of 10 young urethane anesthetized rabbits during stepwise reduction of arterial pressure, using intravital microscopy.

To assess the influence of vasomotion on mean local vascular resistance, the effective vascular diameter (Deff), as a measure of mean flow carrying capacity, was calculated. 
The contribution of vasomotion to the mean local resistance is limited in TAs, but important in FOS, dominating the flow fluctuations in the downstream capillaries.

During pressure reduction, an over-all increase in vasomotion cycle length and amplitude was found in both TAs and FOS, concomitant with an increase in Deff and a decrease in blood flow (Q) and reduced velocity (U), as a measure of wall shear rate. Autoregulation was observed in $70 \%$ of the arterioles. The changes in cycle length and amplitude showed only limited correlations with Q, U, arterial pressure and Deff. This indicates that it is unlikely that only one of these variables is responsible for the changes in the vasomotion parameters.

\subsection{Appendix}

During vasomotion, blood flow through the vessel is an instantaneous function of time $(\mathrm{Q}(\mathrm{t}))$. According to Poiseuille's law (Burton, 1972), $\mathrm{Q}(\mathrm{t})$ is proportional to the fourth power of the instantaneous vessel diameter, $\mathrm{D}(\mathrm{t})$, assuming that the pressure gradient, blood viscosity and vessel segment length are constant. Mean flow (Q) in a vessel with vasomotion is then given by:

$$
Q \simeq \int_{0}^{T} D^{4}(t) d t / \int_{0}^{T} d t
$$

where $\mathrm{T}=$ duration of an integer number of vasomotion cycles. Mean flow can also be expressed as being proportional to the fourth power of the effective vascular diameter (Deff), a measure of the mean flow carrying capacity of a vessel. $D_{\text {eff }}$ combines the influence of mean vessel diameter and vasomotion parameters:

$$
D_{e f f}^{4}=\int_{0}^{T} D^{4}(t) d t / \int_{0}^{T} d t
$$





\section{ANALYSIS OF VASOMOTION WAVEFORM CHANGES DURING PRESSURE REDUCTION AND ADENOSINE APPLICATION}

\subsection{Introduction}

Vasomotion, i.e. rhythmic changes in vascular diameter, is a common observation in arterioles of skeletal muscle (Johnson, 1980; Meyer et al., 1987 ${ }^{\mathrm{a}}$, Slaaf et al., 1987" ; Tangelder et al., 1984). The cycle length of vasomotion was found to remain unchanged during gradual (Slaaf et al., 1987 ${ }^{\mathrm{a}}$ ) or limited (10 $\mathrm{mmHI}$; Meyer et al., 1988 ) reduction of arterial pressure. However, in preliminary experiments, performed in our laboratory, stepwise pressure reduction over a relatively wide range resulted in an increase in vasomotion cycle length and amplitude concomitant with an increase in vascular diameter. In addition, application of adenosine, which also increased vessel diameter, resulted in inconsistent changes in cycle length and amplitude ${ }^{1}$.

To get more insight into the mechanisms involved in vasomotion control, the clnanges in waveform of the vasomotion patterns during vasodilation, as induced by arterial pressure reduction or local application of adenosine, were analyzed. Because arteriolar function might differ at various levels in the microvascular tree (Lindbom and Arfors, 1984; Wiedeman et al., 1981), waveforms, as obtained in arterioles mainly involved in the distribution of blood over the muscle and in arterioles controlling capillary flow, (Slaaf et al., $1987^{2}$ ) were compared. The experiments were performed on the rabbit tenuissimus muscle with the use of intravital video microscopy.

${ }^{1}$ These data have been presented at the Microcirculatory Society Meeting in Las Vegas, May 1988 (abstract: Oude Vrielink et al., The FASEB Journal 2: M117, 1988). 


\subsection{Materials and methods}

Anirnal preparation: the experiments were performed on the tenuissimus muscle of 14 young (5-6 weeks) mixed breed rabbits of either sex, ranging in weight between 700 and $1000 \mathrm{~g}$. Anesthesia was induced by injecting $5 \mathrm{mg} / \mathrm{kg}$ diazepam i.m. After 30 minutes, $4.5 \mathrm{ml} / \mathrm{kg}$ of a solution of urethane (20\% in saline) was administered intravenously in about 4 minutes. If necessary, additional doses of urethane (generally less than $0.3 \mathrm{ml}$ per hour) were given during the experiment.

To facilitate breathing, the trachea was cannulated. Arterial pressures were recorded via catheters in the left common carotid artery $\left(P_{\text {car }}\right)$ and the right femoral artery (Pfem), using CTC CP-01 pressure transducers. These catheters were also used for continuous infusion of physiological saline ( $2.5 \mathrm{ml} / \mathrm{h}$ through each catheter) to compensate for respiratory fluid losses.

Pressure in the arteries supplying the hind limbs could be reduced by inflating a cuff placed retro-peritoneally around the descending aorta distal to the renal arteries. The pressure in the right femoral artery could be set at any level between control pressure and $10 \mathrm{mmHg}$ by means of a servo-system, as described in detail before (Prinzen et al., 1987).

The preparation of the tenuissimus muscle of the left hind limb has been described elsewhere (Reneman et al., 1980). In short, after making a skin incision and cutting the subcutaneous connective tissue, the muscle was exposed by reflection of the biceps femoris muscle. From its first exposure on the muscle was suffused with physiological saline. To allow transillumination of the muscle an incision was made in the connective tissue posterior to the tenuissimus muscle. Subsequently, the hind limb was placed in a box that could be sealed to control the gas environment and a light pipe for transillumination was positioned underneath the tenuissimus muscle (Reneman et al., 1980). The box was mounted on the stage of the microscope and suffusion of the muscle was performed with a Krebs solution (composition in $\mathrm{mM}: \mathrm{NaHCO}_{3}, 25 ; \mathrm{KH}_{2} \mathrm{PO} 4,1.2 ; \mathrm{KCl}$, $4.8 ; \mathrm{CaCl}_{2}, 2.5 ; \mathrm{MgSO}_{4}, 1.2 ; \mathrm{NaCl}, 118.4$ ) saturated with $95 \% \mathrm{~N}_{2}$ and $5 \% \mathrm{CO}_{2}$ (actual pH: $7.34 \pm 0.02$ ). The same gas mixture was led through the box. The preparation was allowed to stabilize for 30 minutes.

Microscopic system: the experiments were performed with a Leitz intravital microscope which was adapted to telescopic imaging (Slaaf et al., 1982). Leitz salt water immersion objectives (SW 25x, numerical aperture $=0.6$ or SW $50 \mathrm{x}$, numerical aperture $=1.0$ ) were used. Images were displayed on a monitor (Siemens) through a TV-camera (Bosch Ultricon 4532,1 inch) and recorded on video tape (Sony Betamax) for off-line analysis. Total optical magnification at the front plane of the TV-camera was 51.6 (SW $25 \mathrm{x}$ ) or 103.2 (SW 50x). Transillumination of the muscle was performed with a mercury arc (100W) and a condenser system positioned in front of the light pipe (Reneman et al., 1980). Neutral density filters in the illuminating pathway were used to reduce the light intensity in the muscle to the lowest llevel still yielding a good image on the moni- 
tor.

Arteriolar blood cell velocity ( $\mathrm{Vbc}$ ) was measured on-line using the dual-slit photometric technique (Wayland and Johnson, 1967). Because good velocity recordings could be obtained only at relatively high light intensities, a neutral density filter of $50 \%$ transmittance was interposed between the dual slit light rods and the video camera to reduce the light intensity.

The signals of $\mathrm{P}_{\mathrm{car}}, \mathrm{P}_{\mathrm{fem}}$ and $\mathrm{V}_{\mathrm{bc}}$ were displayed on a physiological recorder (Schwarzer) and stored on video tape simultaneously with the microscopic images via a homebuilt pulse-code-modulation system. This system, which adds a maximum of 8 analog signals to the normal video image, is similar to the one described by Elmore and Johnson (1982), and allows off-line synchronization of arteriolar diameter measurements and the variables measured on-line.

Vascular pattern: transverse arterioles (TAs) branch from the central artery, dichotomize one or more times and frequently form arcading connections with adjacent TAs (chapter 4). Most TAs ultimately run into the anterior fascia, where they form arteriolar-venular shunts. The first order side branches (FOS) of these TAs divide several times before ending in the capillaries. The FOS are considered to be functionally the terminal arterioles, controlling capillary flow, whereas the TAs are mainly involved in blood transport across the muscle (Slaaf et al., 1987 ${ }^{\mathrm{a}}$ ).

Experimental procedure: in a series of 10 animals, reduction of perfusion pressure was performed. In another series of 4 animals, the effect of increasing concentrations of topically applied adenosine (ADO) was studied. In both series of experiments a TA was selected that clearly showed vasomotion and that could be observed in focus over a sufficient length (usually a distance of more than $1000 \mu \mathrm{m}$ between the most proximal part of the TA and the muscle edge). This TA was recorded on video tape and a drawing of it was made. With the use of this drawing 3-8 measuring sites were selected, where FOS branched from the TA. The measuring sites were chosen along the wholle length of the TA.

At the beginning of a perfusion pressure reduction experiment, each measuring site was videotaped during a control period of 1-2 minutes, while $P_{c a r}, P_{f e m}$ and $V_{b c}$ were recorded simultaneously. Subsequently, $\mathrm{P}_{\mathrm{fem}}$, as measured in the contralateral limb, was reduced by lowering the reference level of the feed-back occlusion system. The pressure adjustment usually took less than 10 seconds. After a stabilization period of 0.5 to 1 minute, the first measuring site was recorded and the various variables were measured again during 1-2 minutes. Pressure reduction was performed in steps of approximately $10 \mathrm{mmHg}$. After release of the aortic occlusion, a stabilization period of approximately 5 min followed before the procedure was repeated at the next measuring site.

The procedure followed during the adenosine application experiments was different from the protocol described above. In these experiments all measuring sites were recorded in the control situation and subsequently at each of the different ADO concen- 
trations. ADO was initially applied at a concentration of $10^{-9} \mathrm{M}$ after which the preparation was allowed to stabilize during a period of 5 minutes before recording the measuring sites again. This procedure was repeated at increasing concentrations of ADO until a concentration of $10^{-3} \mathrm{M}$ was reached (increases in steps of 10 times higher concentrations).

Off-line analysis: the instantaneous arteriolar diameter (D) of TAs and FOS was measure by replaying the videotapes at reduced speed ( $20 \%$ of control), using a homebuilt image shearing device similar to the one described by Intaglietta and Tompkins (1973). The calibrated output signal of the shearing device and the recorded signals of

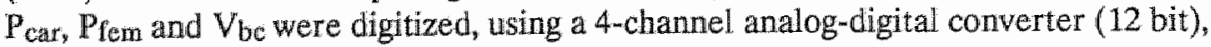
and were stored on floppy disk (Digital Equipment Corporation, MINC-11 computer). A maximum of 2.5 minutes (real-time) of the video-tape could be stored in 1 data file (sampling frequency: $10 \mathrm{~Hz}$ ). All data on floppy disk were obtained as an instantaneous function of time.

From these data blood flow (Q) was calculated using the following equation:

$$
Q=\frac{\pi}{4} D^{2} V_{b c} / B
$$

where $\beta$ is a proportionality factor to transform $V_{b c}$ to mean blood velocity.

Since $\beta$ depends on the ratio between effective dual-slit sensor width and the actual arteriolar diameter (Pittman and Ellsworth, 1986), it was calculated for each diameter. Reduced velocity $(U)$, as a measure of wall shear rate, was calculated from $V_{b c} / \beta D$. The effective vascular diameter ( $D_{\text {eff }}$ ), as a measure of mean flow carrying capacity, was calculated directly from the digitized diameter tracings with the use of the following equation:

$$
D^{4} \mathrm{eff}=\int_{0}^{T} \mathrm{D}^{4}(t) d t / T
$$

where $\mathrm{D}(\mathrm{t})$ is the instantaneous diameter and $T$ is an integer number of cycles (chapter 5).

Mean values of $P_{c a r}, P_{f e m}, V_{b c}, D, D_{\text {eff, }} U$ and $Q$ were computed for each observation period.

Vasomotion parameters (see figure 7.1) were derived from the diameter tracings as recorded during each observation period for both TAs and FOS. For each vasomotion cycle, cycle length (CL, being the time difference between the onset of two consecutive cycles), amplitude ( $A$, being the difference between maximal and minimal diameter during that cycle), duration of the dilation phase ( $T$ dil, being the time difference between the onset of dilation and that of constriction), rate of dillation ( $\mathrm{R}_{\mathrm{dil}}$, 
being the increase in diameter per unit time of the dilation phase), duration of the constriction phase ( $T_{\text {con }}$, being the time difference between the onset of constriction and that of dilation) and rate of constriction ( $R_{c o n}$ being the decrease in diameter per unit time of the constriction phase) were assessed. R dil was calculated from the slope of the straight line between the onset of dilation and a point at which $75 \%$ of the dilation was reached. $R_{\text {con }}$ was obtained analogously. The number of cycles analyzed during each observation period was generally more than 7 . The relative vasomotion amplitude (RA) was calculated by dividing $A$ by the arythmic mean vascular diameter (D). The maximal diameter during vasomotion was taken as a measure of the degree of stretching of the arteriolar wall. For each observation period, mean values of all parameters were calculated. The vasomotion cycle could be divided into 4 different phases (see figure 7.1). The plateau length in the dilation phase was estimated as $\left(T_{\text {dil }}-A / R_{\text {dil }}\right)$ in which $A / R_{\text {dil }}$ equals the estimated time to peak-amplitude. Analogous calculations were made for estimating the time to valley-amplitude and the plateau length in the constriction phase.

The most proximal part of a FOS, i.e. the area where complete closure of the vascular lumen occurs during vasomotion, could be observed in sharp focus simultaneously with the TA in a limited number of experiments. Only these FOS were used for analysis of
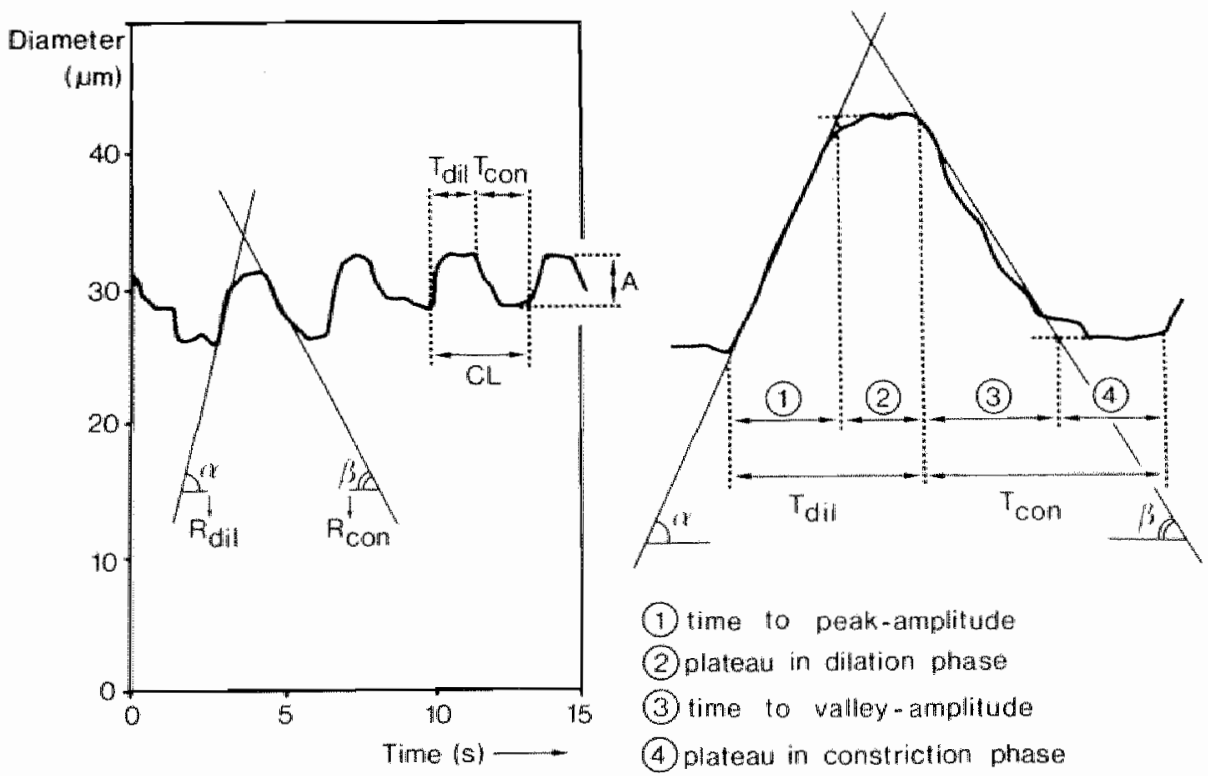

FIGURE 7.I: Example of a vasomotion pattern of a transverse anteriole (left panel), in which vasonotion waveform parameters are indicated: cycle length (CL), amplitude $(A)$, duration of divation phase $\left(T_{\text {dil }}\right)$ and duration of constriction phase ( $\left.T_{\mathrm{con}}\right)$. Rate of dilation ( $\left.R_{\mathrm{dil}}\right)$ and rate of constriction ( $\left.R_{\mathrm{con}}\right)$ were calculated from slopes $\alpha$ and $\beta$, respectively. Right panel: Subdivision of $C L$ into 4 periods, as indicaled. 


\begin{tabular}{|c|c|c|c|c|}
\hline$=\widetilde{F}$ & 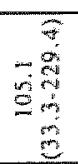 & ' & $\begin{array}{r}0 \\
0.8 \\
\text { is } \\
-0 \\
y \\
y\end{array}$ & ; \\
\hline$\sigma \stackrel{\Xi}{\Xi}$ & 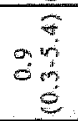 & ' & $\begin{array}{r}a \\
0 \\
0 \\
0\end{array}$ & . \\
\hline 氖 & 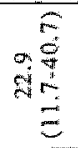 & $\begin{array}{r}\widehat{n} \\
0 \\
0 \\
0 \\
0 \\
0\end{array}$ & $\begin{array}{r}6 \\
0 \\
0 \\
\infty \\
-\infty \\
0 \\
0\end{array}$ & 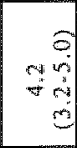 \\
\hline 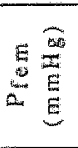 & 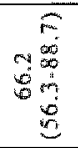 & 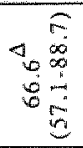 & $\frac{a}{2}$ & 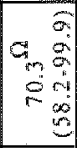 \\
\hline $5 \frac{\widehat{a}}{0}$ & 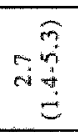 & 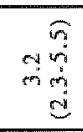 & 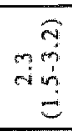 & $\begin{array}{r}6 \\
0 \\
-8 \\
-2 \\
\end{array}$ \\
\hline$\Xi \frac{\widehat{a}}{\tilde{E}}$ & 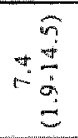 & $\begin{array}{rl} & \hat{a} \\
= & \frac{0}{b} \\
0 & 0\end{array}$ & $\begin{array}{r}\hat{r} \\
0 \\
0 \\
0 \\
\dot{d}\end{array}$ & $\begin{array}{r}5 \\
\infty \\
\infty \\
-3 \\
0\end{array}$ \\
\hline 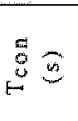 & 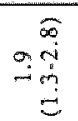 & 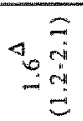 & 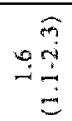 & 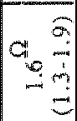 \\
\hline$\sqrt{5}$ & 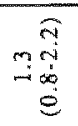 & 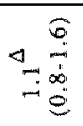 & $\stackrel{\substack{0 \\
e}}{e}$ & 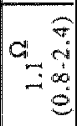 \\
\hline$\widehat{s}$ & 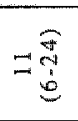 & 잉 & 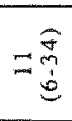 & $=\frac{\widehat{\widehat{c}}}{8}$ \\
\hline$\Leftrightarrow \vec{E}$ & 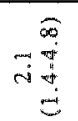 & 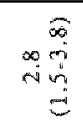 & 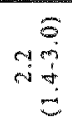 & $\begin{array}{r}3 \\
20 \\
0\end{array}$ \\
\hline$d \approx$ & $\frac{E}{d}$ & $\vec{m}$ & 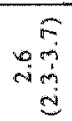 & 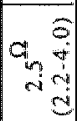 \\
\hline & 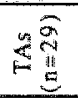 & $8 \stackrel{5}{11}$ & $\sum_{0}^{n}$ & $8 \stackrel{5}{5}$ \\
\hline & 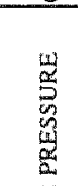 & $\frac{m}{2}$ & 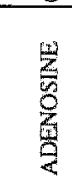 & 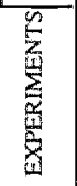 \\
\hline
\end{tabular}


A, RA, Rdil, $R_{\text {con }}$ and $\mathrm{Deff}_{\text {ef }} \mathrm{CL}$, however, appeared to be constant over the whole active length of a FOS. Therefore, vasomotion tracings of all FOS, including those in focus more distally, were used for analysis of $\mathrm{CL}, \mathrm{T}_{\mathrm{dil}}$ and $\mathrm{T}$ con.

Data processing and statistics: for each measuring site, changes in vasomotion parameters during arterial pressure reduction and $\mathrm{ADO}$ application, as compared to control, were calculated. Correlations between the data were described by the lowest order (linear or polynomial) best-fit. To test the regressions for their statistical significance, Student"s t-test was used. Differences between the fits were evaluated for statistical significance by means of an analysis of covariance.

Because no systematic differences could be detected between the values as measured at the various sites along the vascular tree, all data were pooled. The data are presented as median values and ranges. Differences between the groups of pooled data were tested using a sign test. In all tests a 5\% level of statisticall significance was used.

\subsection{Results}

The control values of all parameters in both experimental groups are given in table 7.1. Note that most vasomotion parameters in TAs and FOS are comparable. Changes in the pooled data of the parameters during arterial pressure reduction and adenosine application are shown in figure 7.2 (TAs) and figure 7.3 (FOS).

In TAs, pressure reduction resulted in an increase in vasomotion CL, A and RA concomitant with an increase in $D_{\text {eff, while }} \mathrm{Q}$ decreased. A limited autoregulation range was observed. Vasomotion disappeared at pressure levels between 18.8 and 59.2 $\mathrm{mmHg}$. Reduced velocity, which is not displayed in figure 7.2, decreased from 105.1 $\mathrm{s}^{-1}$ cluring control to $13.6 \mathrm{~s}^{-1}$ at the lowest pressure level reached (median values). Adenosine application did not result in systematic changes in CL and A (figure 7.2, lower panel). Since $\bar{D}$ increased, RA significantly decreased. Vasomotion disappeared at adenosine concentrations between $10^{-7}$ and $10^{-5} \mathrm{M}$. Starting at $10^{-7} \mathrm{M}$ adenosine, $\mathrm{Q}$ showed a pronounced increase. Reduced velocity increased from $125.9 \mathrm{~s}^{-1}$ during control to $206.9 \mathrm{~s}^{-1}$ at $10^{-3} \mathrm{M}$ (median values). Note that during both interventions Deff was the only parameter that changed in the same direction.

In FOS, the changes in most parameters during pressure reduction and adenosine application (figure 7.3) were more or less similar to those in TAs. However, the increase in Deff was more pronounced in FOS than in TAs during both interventions. Furthermore, during adenosine application vasomotion amplitude decreased in FOS and not in TAs. In FOS and TAs, the maximal diameter during vasomotion increased during pressure reduction and adenosine application.

The following analysis of the vasomotion waveforms was performed independent of the actual values of $\mathrm{D}_{\mathrm{eff}} \mathrm{Q}$ and $\mathrm{U}$. Taking into account these values did not result in 


\section{TRAMSVERSE ARTERIOLES}
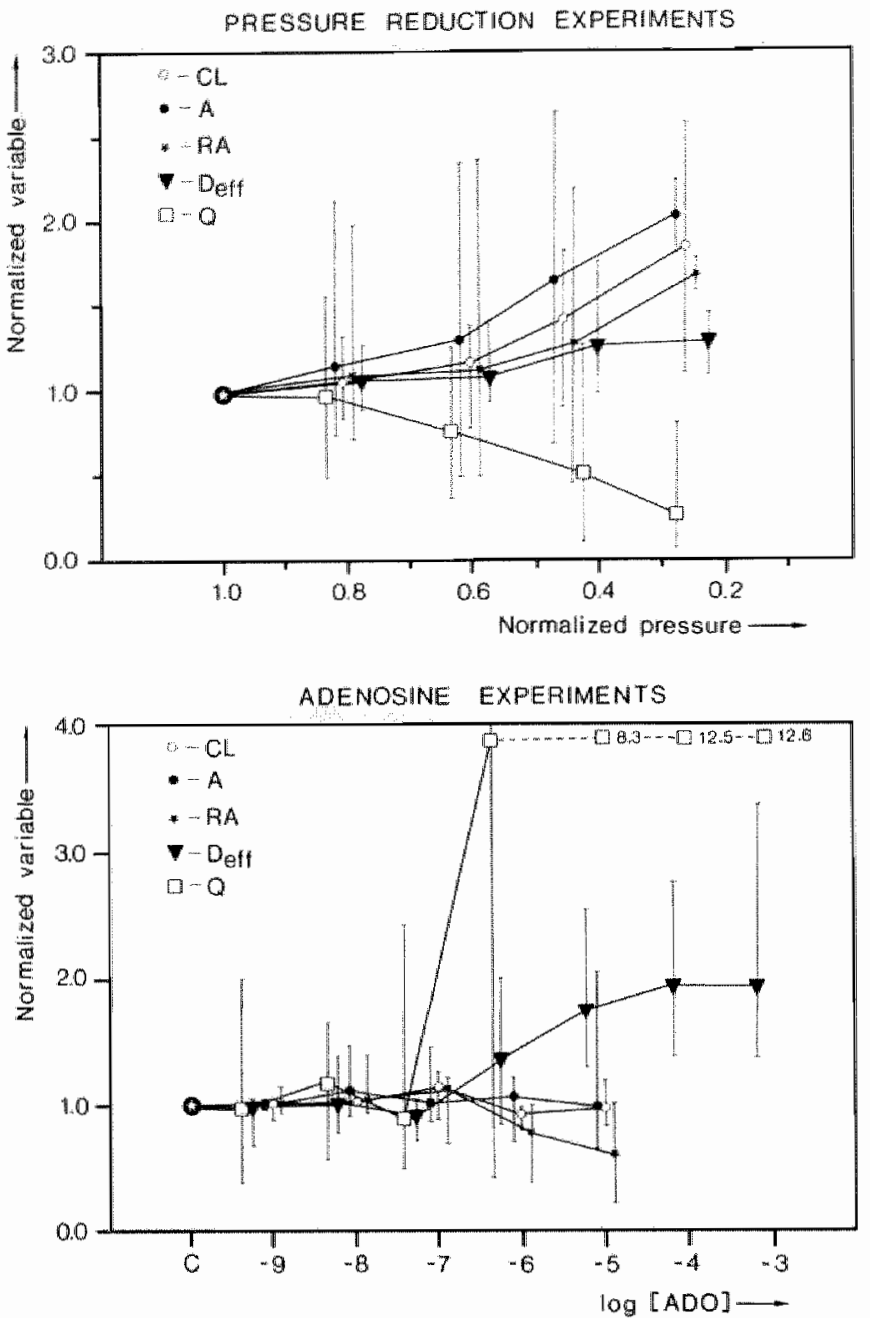

FIGURE 7.2: Changes in wasomotion cycle length (CL), amplitude $(A)$, relative amplitude (RA), effective vascular diameter ( $D_{\mathrm{eff}}$ ) and local blood flow $(Q)$, nomalized to control, as a function of arterial pressure, nomtalized to control (upper panel), or adenasine $(A D O)$ concentration (lower panel; $C=$ control) in TAs. Symbols indicate median wathes in bolh vertical and horizontal direction. For the sake of clarity, only $C L$ is plotted at the proper position on the abscissa. Only in vertical direction, ranges are indicated by bars. 


\section{FIRST ORDER SIDE BRANGHES}
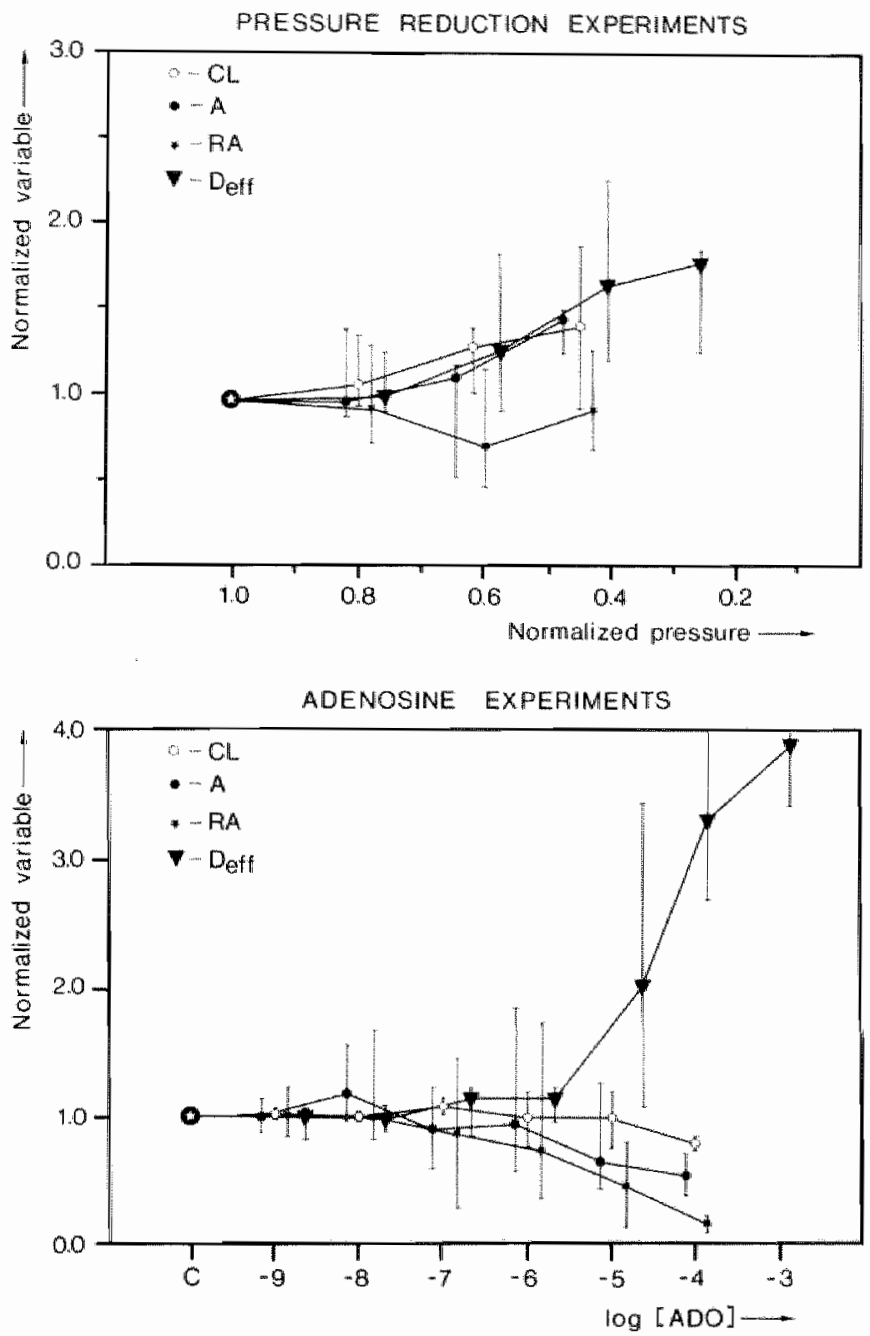

FIGURE 7.3: Changes in vasomotion cycle length (CL), amplitude (A), relative amplitude (RA) and effec-

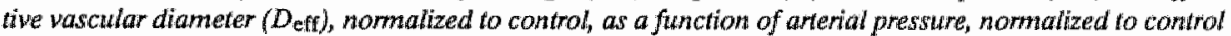
(upper panel), or adenosine (ADO) concentration (lower panel; $C=$ control) in FOS. Symbols indicate miediant values in both vertical and horizontal direction. For the sake of clarity, only $C L$ is plotted at the proper position on the abscissa. Only in ventical direction, ranges are indicated by bars. 
better correlations.

\section{Changes in vasomotion cycle length}

Arterial pressure reduction: the relations between the absolute changes in $\mathrm{CL}$ on the one hand and changes in the duration of the dilation and constriction phases on the other for both TAs and FOS are shown in figure 7.4. In TAs (left panels), the results are best described by second order polynomials, since linear fits demonstrated a systematic error in the lower range of CL changes. The fits indicate that limited changes in CL are the result of changes in duration of both the dilation and the constriction phase, while more pronounced changes are mainly the result of changes in duration of the dilation phase. This is supported by the only extreme change in CL (5.4 s), a value not included in the fits.

In FOS, both the pronounced and the limited changes in $\mathrm{CL}$ were primarily the result of changes in duration of the dilation phase (figure 7.4, right panels). Description of

TRANSVERSE ARTERIOLES
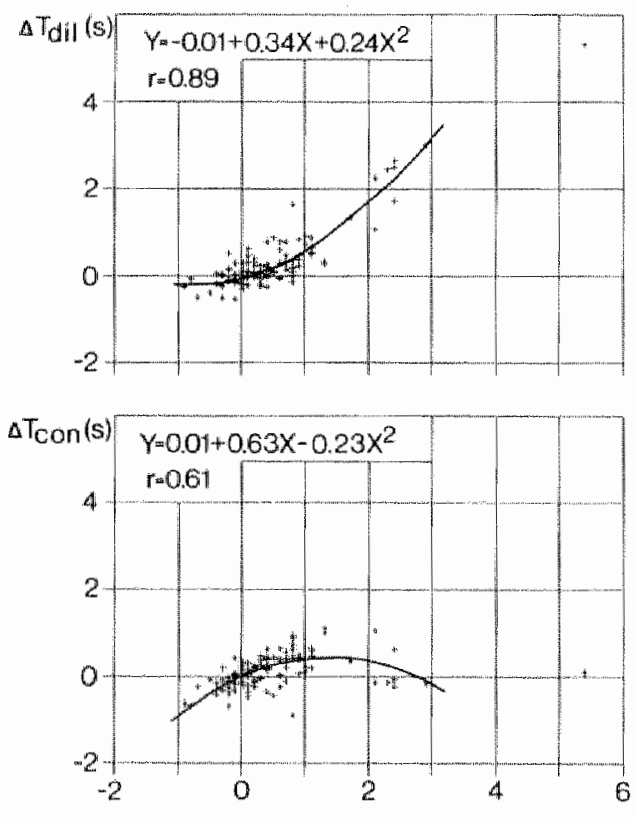

FIRST ORDER SIDE BRANCHES
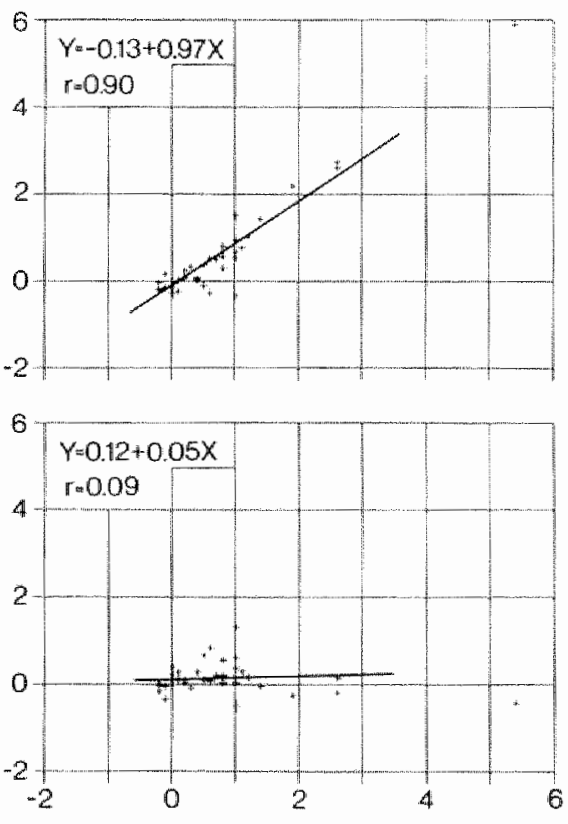

$\triangle \mathrm{CL}$ (s)

FIOURE 7.4: Scatterplots of the changes in duration of the dilation and constriction phase, expressed as the absolvte difference with control ( $\Delta T_{\text {dil }}$ and $\Delta T_{\text {con, }}$ respectively), as a function of changes in cycle length $(\triangle C L)$ for TAs (left) and FOS (righ) during pressure reduction. Besilfits of the data and their correlation coefficients (r) are also presented. 
TRANSVERSE ARTERIOLES

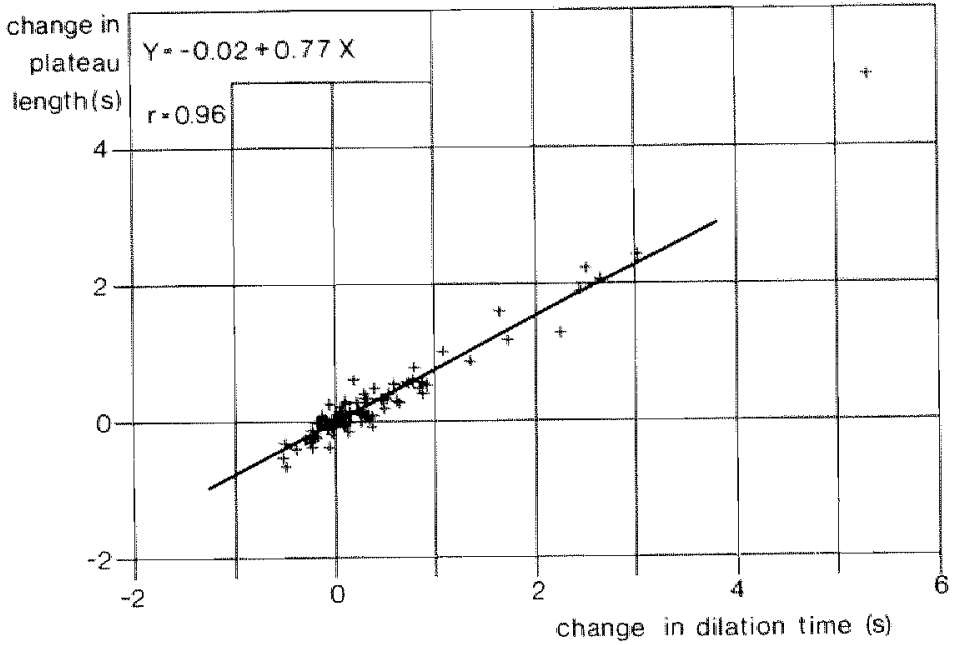

FIRST ORDER SIDE BRANCHES

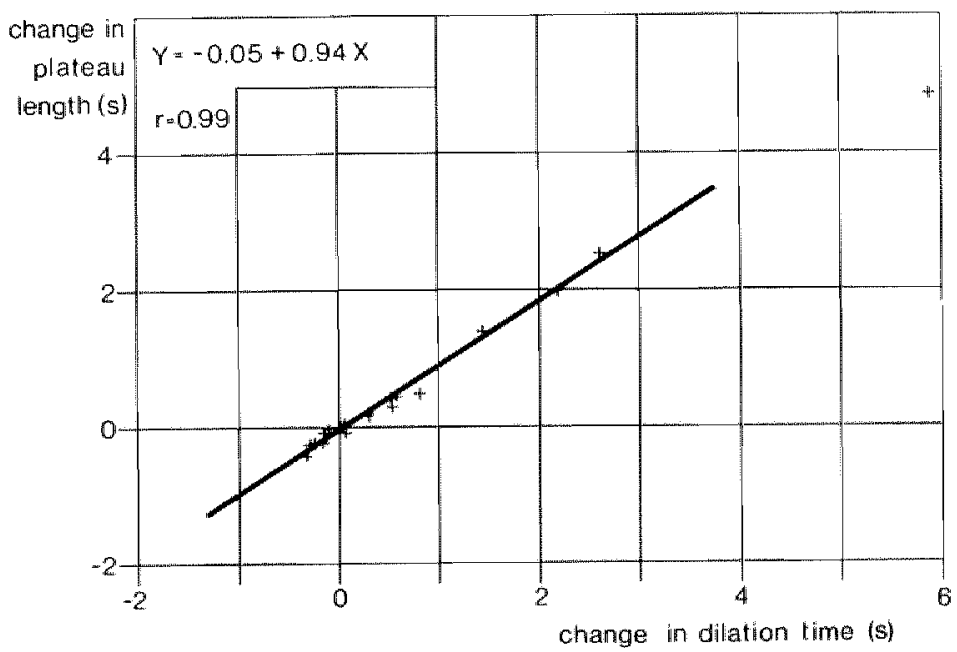

FIGURE 7.5: Scatter plots of the changes in plateau length, expressed as difference with control, as a func* tion of the change in dilation time for TAs (upper panel) and FOS (lower panel) during pressure rediction. Best fits of the data and their correlation coefficients (r) are presented. 


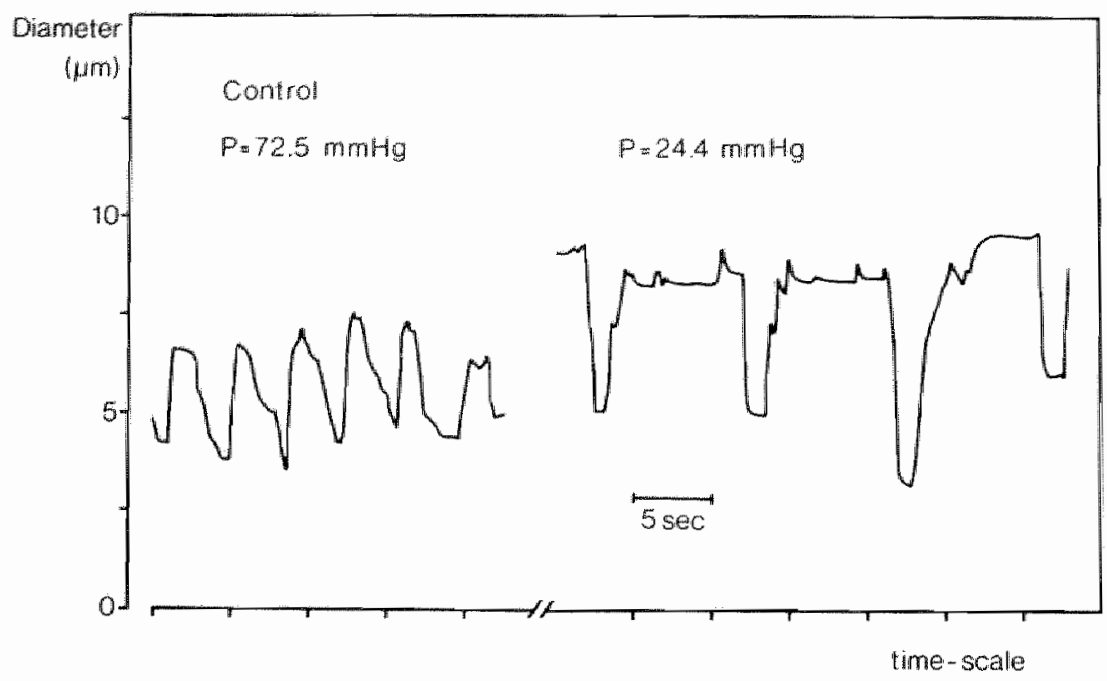

FIGURE 7.6: Example of the occurrence of plateaus in the ditation phase in a FOS when aterial pressure $(P)$ is strongly reduced.

the data with second order polynomials did not result in better fits. The one FOS showing the extreme change in CL $(5.4 \mathrm{~s})$ branched from the TA that showed the same change in CL (see above).

In both TAs and FOS, the changes in the dilation phase were mainly caused by changes in the plateau-length (figure 7.5). This appeared to be consistent for the whole range of CL changes. An example of plateau formation in a FOS is shown in figure 7.6. Changes in duration of the constriction phase, which were only slight, appeared to result approximately equally from changes in time to valley-amplitude and plateaulength.

Adenosine application: the CL changes in TAs and FOS were variable and of the same order of magnitude as the limited, systematic changes observed during pressure reduction. Also the relations between changes in $\mathrm{CL}$ on the one hand and changes in duration of the dilation and constriction phases on the other (figure 7.7) were comparable to those described above for the limited CL changes during pressure reduction (c.f. the figures 7.4 and 7.7 : note the difference in scaling between both figures). The data were best described by linear fits. These fits demonstrate that in TAs, the CL changes were the result of changes in duration of both the dilation and the constriction phase, and in FOS of changes in duration of the dilation phase alone.

In both TAs and FOS, the changes in the dilation phase resulted mainly from changes in the plateau-length. Changes in duration of the constriction phase were due to comparable changes in time to valley-amplitude and plateau-length. 
TRANSVERSE ARTERIOLES
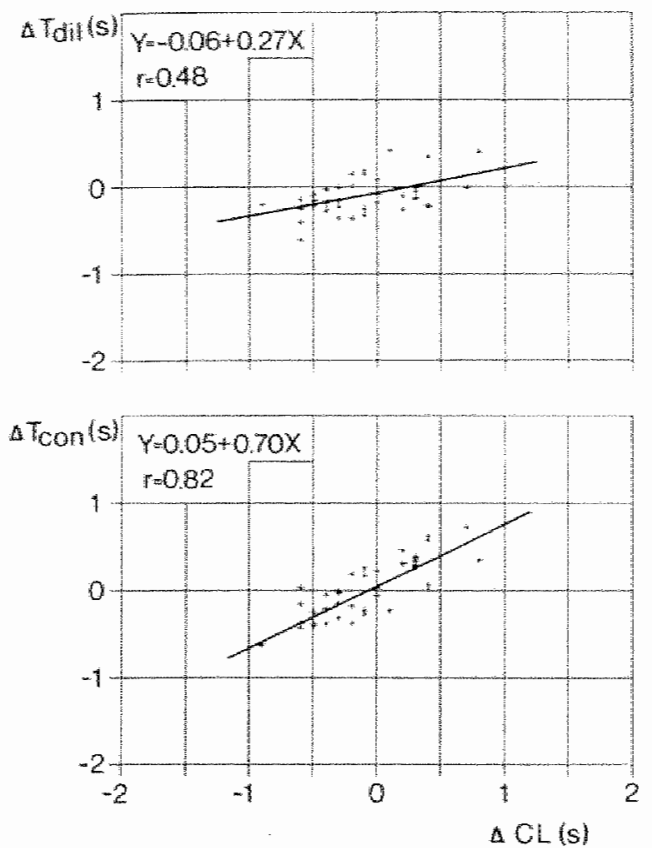

FHST ORDER SIDE BRAMCHES
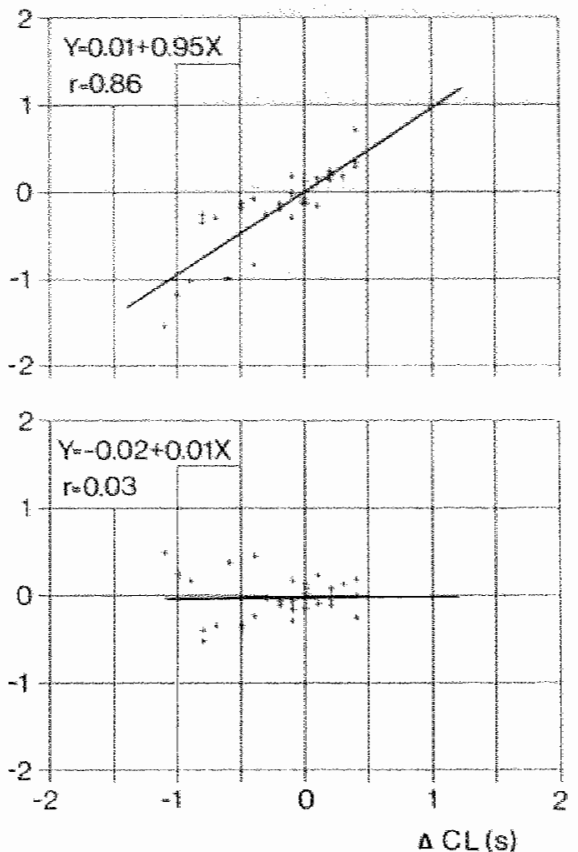

FIGURE 7.7: Scatter plots of the changes in dwration of the ditation and constriction phases, expressed as the absolute difference with control ( $\Delta T_{\mathrm{d}} \mathrm{a}$ and $\Delta T_{\mathrm{con}}$ respectively), as a function of changes in vasomotion cycle length ( $\triangle C L$ ) for $T A S$ (left) and FOS (right) during adenosine application. Best linear fits of the data and their correlation coefficients ( $r$ ) are given.

\section{Changes in vasomotion amplitude}

Arterial pressure reduction: changes in vasomotion amplitude did not correlate with the changes in $\mathrm{CL}$, $\mathrm{T}_{\text {dil }}$ or $\mathrm{T}_{\mathrm{con} \text {. }}$ Vasomotion amplitude was not related to the maximal diameter during vasomotion, or to $\mathrm{R}_{\mathrm{dil}}$, which remained essentially constant in all experiments. However, $A$ correlated significantly with $R_{\text {con }}$ (figure 7.8 , upper panels; note that the displayed values are normalized to control). The regression lines of TAs and FOS were not significantly different. Also $\mathrm{R}_{\mathrm{con}}$ did not correlate with the maximal diameter during vasomotion.

Adenosine application: in both TAs and FOS, the variations in amplitude did not correlate with variations in $\mathrm{CL}, \mathrm{T}_{\mathrm{dil}}, \mathrm{T}_{\mathrm{con}}, \mathrm{R}_{\mathrm{dil}}$ or maximal diameter during vasomotion. However, amplitude correlated significantly with the rate of constriction (figure 7.8, lower panels). Again, the fits of TAS and FOS were not significantly different. However, in both TAs and FOS, the regression lines were significantly steeper during adenosine application than during arterial pressure reduction. 
TRANSWEASE ARTERIOLES
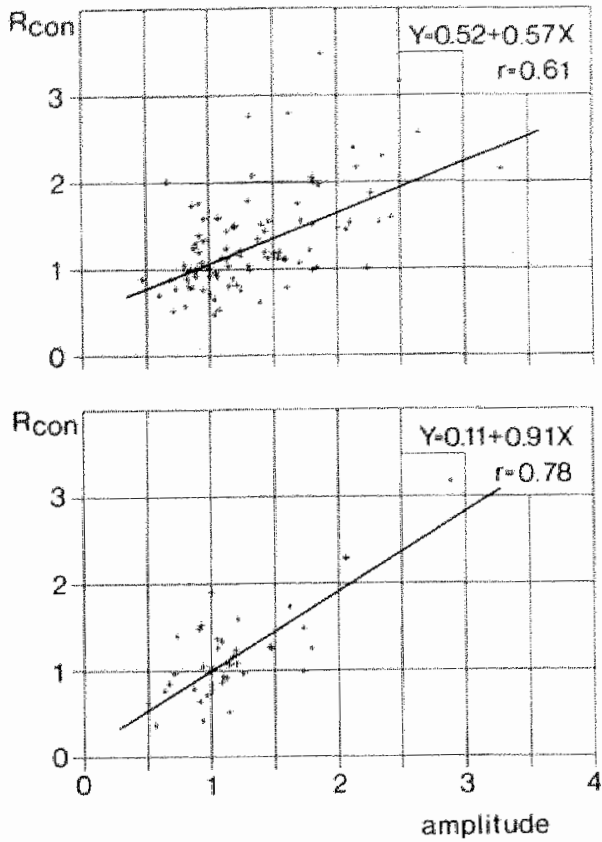

FIRST OFDER SIDE BRANCHES
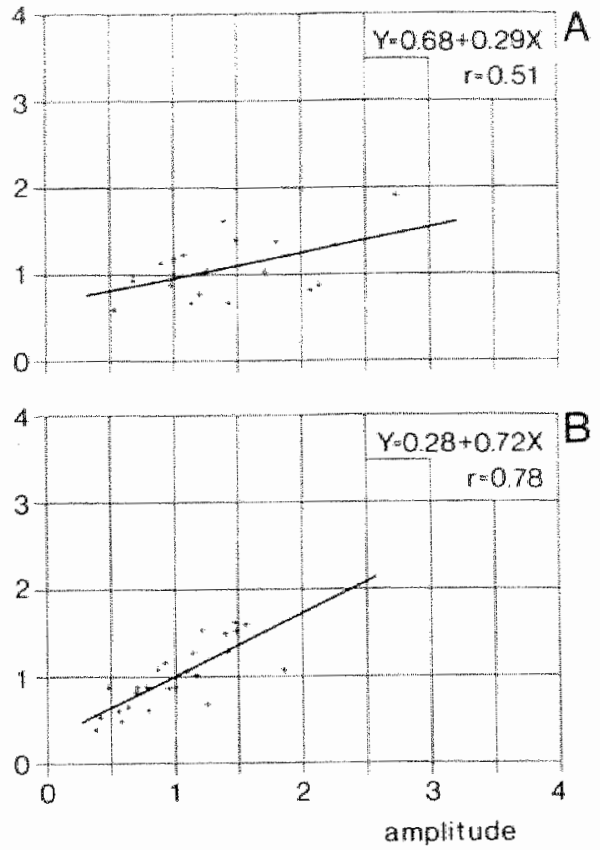

FGURE 7.8: Scatter plots of the rate of constriction, normalized to control $\left(R_{60 n}\right)$, as a funtion of vasomotion amplitude, normalized to control, for TAs (left) and FOS (right) diring arterial pressure reduction (A, upper pastels) and adenosine application ( $B$, lower panels). Best linear fits of the data and their correlation coefficients (r) are given.

\subsection{Discussion}

The findlings in the present study show that vasomotion cycle length and amplitude increase with stepwise reduction of arterial pressure, concomitant with an increase in effective vascular diameter. Limited changes in cycle length are associated with similar changes in both the dilation and the constriction phase in TAs and with changes in the dilation phase in FOS. Pronounced cycle length changes are associated with plateau formation in the dilation phase in TAs and FOS. Adenosine application also results in an increase in effective diameter, but in a variable change in vasomotion cycle length and amplitude. The changes in cycle length are associated with similar changes in the dilation and constriction phase as compared to the limited cycle length changes during pressure reduction. Since the maximal diameter increases during both interventions it is unlikely that increased stretch of the arteriolar wall leads to a change in the vasomotion waveform.

The present observation that vasomotion cycle length increases during pressure reduc- 
tion is not necessarily in disagreement with the findings of Meyer and co-workers $\left(1988^{\mathrm{a}}\right)$ and Slaaf and colleagues $\left(1987^{\mathrm{a}}\right)$, who did not observe changes in vasomotion cycle length during pressure reduction. The conclusions of Meyer and co-workers $\left(1988^{\mathrm{a}}\right)$ were based on a pressure reduction of only $10 \mathrm{mmHg}$, a decrease in pressure which also does not show systematic changes in cycle length in the present study (figures 7.2 and 7.3 , upper panels). Slaaf and colleagues (1987 $)$ reduced pressure stepwise initially, but gradually in the low pressure range. These gradual reductions were probably too fast to observe changes in the vasomotion pattern.

From figure 7.6 one may conclude that during arterial pressure reduction the pronounced increases in vasomotion cycle length can be explained by regular suppression of one or more cycles. However, the increase in cycle length in individual arteriolar segments is gradual from pressure step to pressure step and is always smaller than the length of one cycle. Therefore, suppression of vasomotion cycles does not explain the observation that cycle length increases during pressure reduction.

In preliminary experiments it was found that vasomotion cycle length is identical in adjacent arterioles during the whole range of pressure reductions (chapter 6). Furthermore, in the present study it is demonstrated that the vasomotion waveform changes are different in TAs and FOS when limited cycle length changes are induced by either stimulus applied. This finding indicates a difference between TAs and FOS in the ratio between the duration of the dilation and the constriction phase. In order to investigate the synchronization of the dilation or the constriction phase, in 5 FOS and their feeding TAs the onsets of dilation and constriction were compared. In the control situation, the dilation and the constriction phase start approximately simultaneously in the two types of arterioles. At reduced arterial pressure levels, leading to limited increases in cycle length, the onsets of dilation still occur synchronously, while the onset of constriction is delayed in FOS ( $0.4 \mathrm{~s}$, median value), as compared to their feeding TAs. During pronounced increases in cycle length, both the dilation and the constriction phase are in phase again. These observations are depicted schematically in figure 7.9. The synchronous vasomotion patterns in TAs and FOS in the control situation (bottom tracings) may be modified to different degrees by the stimulus applied. Vasodilation, as induced by limited pressure reductions or adenosine application, may result in a slightly more prolonged dilation phase in FOS than in TAs due to a delayed onset of constriction in the FOS (middle tracings). This is in accordance with the observation that a limited change in cycle length is accomplished almost completely by a change in dilation time in FOS, but only to a limited extent in TAs. Vasodilation, as induced by prow nounced pressure reductions, may result in a large increase in cycle length associated with synchronous vasomotion patterns in TAs and FOS (top tracings). This finding is in agreement with the observation that in both TAs and FOS the pronounced cycle length changes are mainly caused by prolongation of the dilation plateaus. It is interesting to note that the onset of dilation rather than the onset of constriction occurs at the same time in TAs and FOS.

The occurrence of vasomotion at regular intervals, independent of external stimuli and simultaneous in TAs and FOS led Meyer and co-workers $\left(1987^{\mathrm{a}}, 1988^{\mathrm{a}}\right)$ to the conclu- 


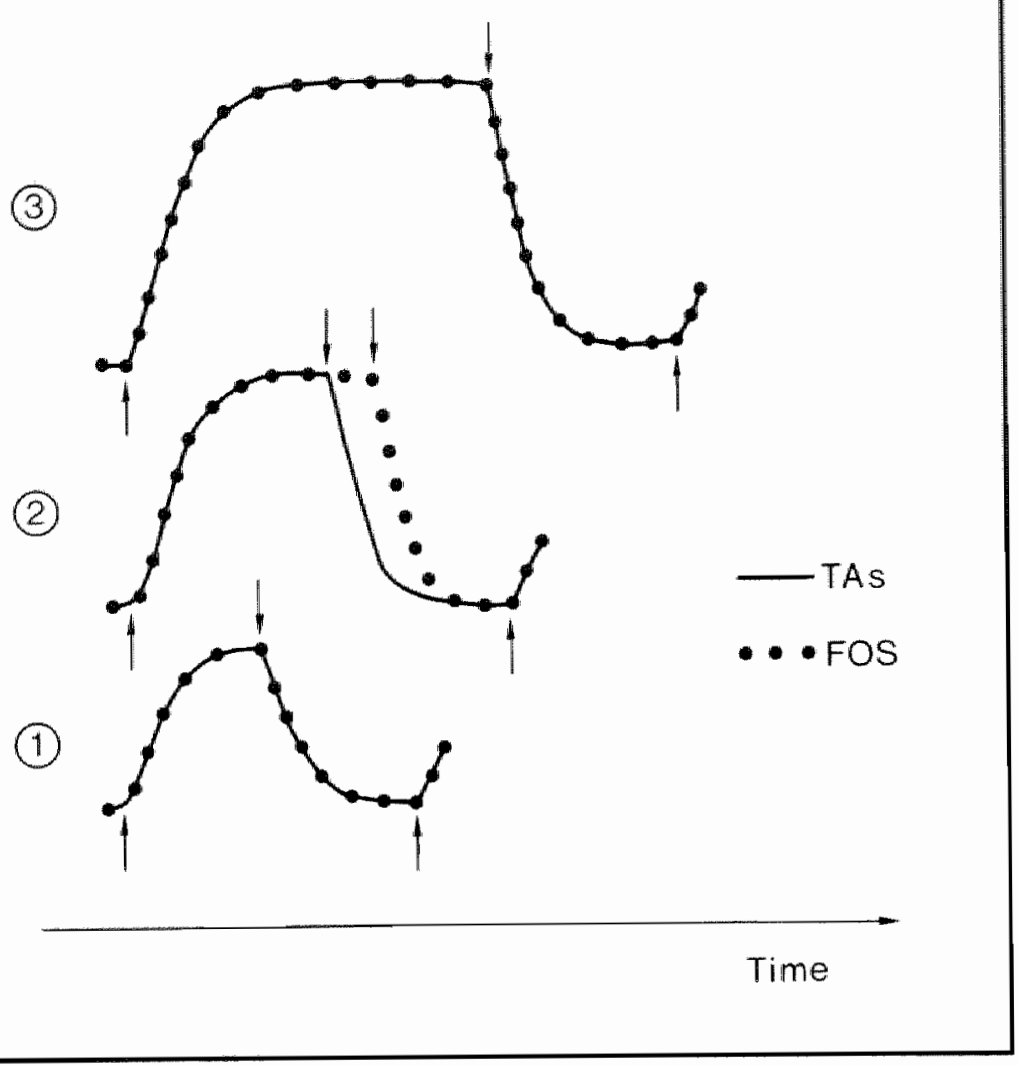

FIGURE 7.9: Schematic drawing summarizing the changes in vasomotion waveform in TAs and FOS. $1=$ control situation; $2=$ limited change in cycle length; $3=$ strong increase in cycle length. The arrows indicate the onsets of dilation and constriction.

sion that vasomotion is induced by pacemaker activity of smooth muscle cells, located in the most proximal part of the FOS. Although in the present experiments vasomotion cycle length could be modified by external stimuli, this finding is not necessarily in disagreement with the hypothesis that wasomotion is controlled by a pacemaker (c.f. the heart rhythm). However, detailed analysis of the vasomotion waveform shows that the onsets of constriction do not occur synchronously in adjacent vessels when limited cycle length changes are induced. If a pacemaker in the classical sense of the word, i.e. a dominating initiator of muscle cell activation, would be present, the onsets of constriction in TAs and FOS should occur synchronously. The present data, however, show that the onsets of dilation rather than the onsets of constriction occur synchronously, which is not compatible with the presence of a classical pacemaker. If it still were to be a pacemaker-like activity, dominating the vasomotion pattern, it functions as a rhyth- 
mic inhibitor of smooth muscle cell activity rather than as a rhythmic activator. In such a mechanism the duration of the dilation phase may depend on local factors, resulting in different onsets of constriction.

The similarity in the limited changes in vasomotion waveform during pressure reduction and adenosine application, independent of parameters as local blood flow or wall shear rate, is indicative of a common mechanism involved in the changes in vasomotion pattern during these stimuli. Our knowledge of such a mechanism is still poor. It is unlikely that stretch of the arteriolar wall, as has been suggested by Folkow (1964), is a determinant factor. During arterial pressure reduction vasomotion cycle length and amplitude increase with a concomitant increase in wall stretch, while during adenosine application an increase in wall stretch can be associated with unaltered cycle length and amplitude. The present study cannot be conclusive about the involvement of local blood flow or wall shear rate in vasomotion control. A reduction of both variables is associated with an increase in cycle length and amplitude (figures 7.2 and 7.3, upper panels), but an increase in local blood flow or wall shear rate usually does not lead to a decrease in the vasomotion parameters. Johnson (1980) has suggested wall tension to be involved in the control of vascular tone. Since wall tension is likely to decrease during pressure reduction (Burrows and Johnson, 1981) and to increase during adenosine application, in the present study opposite changes in wall tension are not associated with opposite changes in the vasomotion parameters. Only a substantial decrease in wall tension leads to a distinct change in the vasomotion pattern. It is interesting to note that these changes are similar to those observed during changes in blood flow and wall shear rate.

An implication of the present finding that vasomotion cycle length and amplitude do not correlate during either stimulus may be that these vasomotion parameters are not controlled by the same mechanism. This might point to a different control of periodicity and strength of the rhythmic contractions. For periodicity, the dilation phase seems to be the most important phase because cycle length is synchronized at the onset of dilation and the major changes in this parameter are found to be caused by changes in the dilation phase. The rate of constriction is not influenced by the degree of dilation -an indication of the extent of stretching of the arteriolar wall]-, but relates to the distance over which the contraction occurs, as indicated by the significant correlation between this parameter and vasomotion amplitude. Therefore, vasomotion seems to be a series of rhythmic dilations, the amplitude of which is determined by the rate of constriction.

In conclusion, arterial pressure reduction is associated with an increase in vasomotion cycle length and amplitude, whereas adenosine application results in variable changes in these parameters. However, the way in which the vasomotion waveform changes of comparable magnitude are accomplished is similar during both stimuli, despite important differences in local blood flow and wall shear rate. The findings indicate that stretch of the arteriolar wall is not involved in vasomotion control. The study leads to the hypothesis that vasomotion is a series of rhythmic dilations. 


\subsection{Summary}

Changes in the vasomotion waveform were studied in transverse arterioles (TAs) and their first order side branches (FOS) in the tenuissimus muscle of 14 young, anesthetized rabbits during stepwise arterial pressure reduction and local application of adenosine, using intravital video microscopy.

Pressure reduction resulted in a systematic increase in vasomotion cycle length (CL) and amplitude (A) concomitant with an increase in effective vascular diameter (Deff) and the maximum diameter, and a decrease in blood flow $(Q)$ and reduced velocity (U), a measure of wall shear rate. At moderate pressure reductions $\mathrm{CL}$ changes were limited (less than 1.5 s) and in TAs resulted from changes in both the dilation and the constriction phase. In FOS, however, the changes in CL were caused by prolongation of the dilation phase alone. Because the onsets of dilation always occur synchronously in TAs and FOS, but the onsets of constriction do not, the present findings are not compatible with the idea that vasomotion is a series of rhythmic contractions. At greatly reduced pressure levels, the increase in CL was more pronounced and in both $\mathrm{TAs}$ and FOS was caused by plateau formation in the dilation phase.

During adenosine application, $\mathrm{D}_{\text {eff }}$ and the maximum diameter also increased, but $\mathrm{CL}$ and $\mathrm{A}$ did not change systematically.

These findings indicate that stretch of the arteriolar wall does not play a role in control of the vasomotion waveform. Vasomotion seems to be a series of rhythmic dilations rather than rhythmic constrictions. 


\section{Chapter 8}

\section{GENERAL DISCUSSION}

In the tenuissimus muscle of the rabbit, the preparation used in this thesis, in the resting situation capillary flow velocity fluctuates rhythmically, which can be observed with the use of intravital microscopy. Rhythmic variations in the diameter of the feeding arterioles, a phenomenon called vasomotion, are the cause of this temporal heterogeneity in capillary perfusion. The consequences of the presence of vasomotion for tissue perfusion and the relation between the changes in vasomotion pattern and local blood flow control are incompletely understood. It was the aim of the present thesis to obtain more insight into the phenomenon of vasomotion at different arteriolar levels in the rabbit tenuissimus muscle and to investigate the relation between vasomotion and muscle blood flow regulation under such experimental conditions as arterial pressure reduction and vasodilation, as induced by adenosine application.

The vascular bed of the tenuissimus muscle consists of a central artery, some transverse arterioles and their first order side branches each feeding several capillaries. Most transverse arterioles ultimately run into the anterior fascia where they form arteriolarvenular shunts. Via transverse venules and a central vein, the blood is drained out of the muscle. In the present thesis it is shown that vasomotion occurs in the transverse arterioles and their first order side branches. Vasomotion in these side branches is often so pronounced that the flow in the downstream capillaries stops for a few seconds. Microvessels not perfused for longer periods of time are not observed in this muscle preparation. Capillary recruitment is found to be absent (chapter 4). The perfusion of all capillaries in the resting situation is probably a consequence of the pronounced vasomotion in the first order side branches. The fast dilation after complete closure of the arteriolar lumen likely results in a substantial increase in the pressure difference over the capillary bed, which does not only lead to perfusion of the widest and shortest capillaries, but also of the capillaries with a relatively high resistance.

For many years, capillary recruitment was thought to be necessary to explain the low perfusion rate of skeletal muscle at rest. The classical idea was that part of the capillaries is not perfused at rest and can be additionally perfused in situations of increased flow demand (Krogh, 1919). The perfused capillaries were thought to be spread regu- 
larly over the tissue with diffusion distances short enough to supply all muscle fibers with oxygen. This line of thinking was possible because blood flow control was assumed to occur at the level of individual capillaries by precapillary sphincters. However, the existence of precapillary sphincters in skeletal muscle has never been demonstrated (Eriksson and Myrhage, 1972; Eriksson and Lissander, 1972). Moreover, capillary flow is controlled in groups of capillaries rather than in individual capillaries (chapter 4). The existence of capillary recruitment in the classical sense of the word would therefore imply flow cessation for longer periods of time in groups of capillaries, which may lead to a relatively low oxygen tension and limited muscle fiber function in certain muscle regions (Duling and Damon, 1987). The present findings indicate that this not the case. Despite the low muscle perfusion all functionally available capillaries are perfused, albeit intermittently. Short periods of fast perfusion, refreshing the blood in all capillaries, alternate with periods of no perfusion, during which exchange of oxygen and waste products occurs over the whole length of the capillaries. A consequence of the present finding is that an increase in blood flow through the muscle can be only accomplished by an increase in mean flowvelocity in the capillaries. This is among others, effectuated by the transition from intermittent to continuous perfusion (chapter 4 ). In fact, this transition may be seen as recruitment of capillaries in time. Therefore, for this phenomenon the term temporal recruitment is proposed.

The absence of capillary recruitment in young rabbit tenuissimus muscle is in accordance with findings in studies in rats (Prewitt et al., 1982) and hamsters (Sarelius et al., 1981). In these studies no microvessel recruitment was found in animals of comparable age. However, it may be that recruitment is a phenomenon which develops during maturation. In the studies of Prewitt and co-workers (1982) and Sarelius and co-workers (1981) in adult animals and using the same protocol, arterioles and capillaries that were not perfused in the control situation could be recruited during vasodilation. It is unsure whether the absence of recruitment, as found in the present study, also holds for other muscles. The occurrence of recruitment of microvessels might differ between various muscles and might depend on the type of fiber composition. The latter is supported by the finding in rabbit soleus muscle, which contains mainly slow oxidative fibers, that $80 \%$ of the total number of capillaries is perfused in the resting situation, while in the anterior tibialis muscle, primarily consisting of fast twitch fibers, of the same animal this number was approximately $60 \%$ (Renkin et al., 1981). Evenso in the chicken latissimus dorsi muscle, at rest the anterior part (slow oxidative fibers) contains a higher percentage of capillaries accessible to flow than the posterior part (fast twitch fibers; Gray et al., 1983).

The present study demonstrates that vasomotion in the transverse arterioles does not contribute to the mean local wascular resistance (chapter 6). This implies that, if these vessels would have had the same mean diameter but without vasomotion, their mean blood flow would have been almost the same. It should be emphasized, however, that transverse arteriolles do contribute to the regulation of local blood flow. Their $50 \%$ increase in effective diameter during vasodilation, as compared to the effective diameter in the control situation (chapter 6), implies a 5 times increase in flow carrying capac- 
ity. It is proposed that the transverse arterioles provide the coarse turing of blood flow regulation, and distribute the blood over relatively large muscle regions. This idea is compatible with the observation that transverse arterioles frequently form arcading connections with neighbouring arterioles (chapter 4; Lindbom and Arfors, 1984). Particularly these arcading structures are extremely well suited to provide a constant supply of blood to large areas (Greene et al., 1988).

The first order side branches of the transverse arterioles are proposed to control the fine tuning of blood flow regulation. In this control vasomotion plays an important role. It contributes significantly to the mean vascular resistance of these branches and completely dominates the perfusion pattern in the downstream capillaries (chapter 6). Because higher order branches do not show vasomotion, the first order side branches are considered to be functionally the terminal arterioles. This implies a relatively high vascular tone during low flow demand, as in the muscle at rest. The present observation that under resting conditions the effective vascular diameter of the first order side branches is only a fraction of their maximal diameter (chapter 6) supports this idea.

The changes in vasomotion pattern in the first order side branches, as observed during arterial pressure reduction, are compatible with their function as described above. The present findings demonstrate that pressure reduction results in an increase in vasomotion cycle length in these arterioles, mainly due to an increase in length of the dilation phase. This change in waveform is apparently a compromise. It would have been more appropriate that vasomotion disappears under these circumstances. During vasomotion, however, the peaks in the pressure difference over the capillary bed still result in a distribution of blood over the muscle tissue as homogeneous as possible, while the prolonged dilation phase compensates for the constriction phase to keep the blood supply at a sufficiently high level. At strongly reduced pressure levels, vasomotion disappears. In this situation, the flow demand might overrule the vasomotion mechanisms. In addition, in this situation the advantage of vasomotion is likely to be small because the pressure peak over the capillary bed is strongly diminished.

The present results demonstrate that arterial pressure reduction leads to an increase in vasomotion cycle length and amplitude, concomitant with an increase in effective and maximum arteriolar diameter. Also during adenosine application these diameters increase, but no systematic changes in the vasomotion parameters are observed. "These findings indicate that the vasomotion changes are not controlled by the degree of stretching of the arteriolar wall, as suggested by Folkow $(1962,1964)$ and Osol and Halpern (1988), because similar changes in wall stretch are observed during pressure reduction and adenosine application. The involvement of local blood flow, wall shear rate or wall tension in vasomotion control remains unclear because only a decrease in each of these parameters results in a systematic change in vasomotion waveform, whereas an increase does not.

The mechanism controlling vasomotion cycle length is incompletely understood. According to Johansson and Mellander (1975), the time derivative of the increase in length of the vessel wall determines the repetition rate of rhythmically occurring contractions in isolated rat portal vein. The same mechanism controlling vasomotion cycle 
length in rabbit teruissimus muscle arterioles is unlikely because in the present experiments the rate of dilation remains essentially constant. Some investigators suggest vasomotion cycle length to be controlled by a pacemaker (Colantwoni et al., $1984^{\mathrm{a}}$, $1985^{\mathrm{b}}$; Intaglietta, 1983; Meyer et al., $1987^{\mathrm{a}}, 1987^{\mathrm{b}}$ ). A pacemaker in the classical sense of the word dominates the activation pattern of the smooth muscle celis in the vascular wall and, hence, must lead to synchronous contractions in adjacent vessels, a phenomenon reported by Meyer and colleagues ( $1987^{a}$ ). The present data (chapter 7 ) clearly show that under certain circumstances contractions do not occur synchronously in the transverse arterioles and their first order side branches. Therefore, the present results do not support the existence of a classical pacemaker in the arteriolar bed of the tenuissimus muscle. Since the onsets of dilation always occur synchronously in both vessel types, it might still be that the vasomotion pattern is dominated by pacemaker-like activity. Then, such a pacemaker has to be a rhythmic inhibitor of smooth muscle cell activity. In such a mechanism the duration of the dilation phase may depend on local factors, resulting in different onsets of constriction. Therefore, it is suggested that wasomotion is a series of rhythmic dilations rather than a series of rhythmic constrictions.

In conclusion, vasomotion is an important phenomenon in the origin of temporal flow heterogeneity in the tenuissimus muscle. The vasomotion pattern can be changed by externally applied stimuli. However, the mechanisms controlling these changes are still incompletely understood. The widespread notion that vasomotion is a series of rhythmic constrictions, the frequency of which is controlled by a pacemaker, is not affirmed by the findings in the present study. On the contrary, vasomotion seems to be a series of rhythmic dilations. 


\section{Chapter 9}

\section{REFERENCES}

Amundson, B., E. Jennische, and H. Haljamäe. Correlative analysis of microcirculatory and cellular metabolic events in skeletall muscle during hemorrhagic shock. Acta Physiol. Scand. 108: 147-158, 1980.

Baez, $S_{*}$ S.M. Feldman, and P.M. Gootman. Central neural influence on precapillary microvessels and sphincter. Am. J. Physiol. 233 (Heart Circ. Physiol. 2): H141-H147, 1977.

Bagge U., and M. Braide. Leukocyte plugging of capillaries in vito. In: White blood cells. Morphology and theology as related to function, edited by U. Bagge, G.V.R. Born, and P. Gachtgens. The Hague, Martinus Nijhoff Publishers, 1982.

Berne, R.M. Adenosine: an important physiological regulator. News in Physiological Sciences 1: 163-167, 1986. Bevan, J.A., and J.E. Brayden. Nonadrenergic neural vasodilator mechanisms. Circ. Res. 60: 309.326, 1987.

Bockman, E.L., R.M. Berne, and R. Rubio. Adenosine and active hyperemia in dog skeletal muscle. Am. J. Physiol. 230: 1531-1537, 1976.

Bohlen, H.G. Arteriolar closure mediated by hyperresponsiveness to norepinephrine in hypertensive rats. Am. J. Physiol. 236 (Heart Circ. Physiol. 5): H1157-H164, 1979.

Borgström, P., P.-O. Grände, and S. Mellander. An evaluation of the metabolic interaction with myogenic vascular reactivity during blood flow autoregulation. Acta Physiol. Scand, 122: 275-284, 1984.

Bouskela, E., and C.A. Wiederhielm. Microvascular myogenic reaction in the wing of the intact unanesthetized bat. Am. J Physiol. 237 (Heart Circ. Physiol. 6): H59-H65, 1979.

Burnstock, $G$. Local control of blood pressure by purines. Blood Vessels 24: 156-160, 1987.

Burnstock, G., and S.G. Griffith. Innervation of microvascular smooth muscle. Prog. appl. Microcirc. 3: 19. 39. 1983 .

Burrows, M.E., and P.C. Johnson. Diameter, wall tension, and flow in mesenteric arterioles during antoregulation. Am. J. Physiol. 241 (Heart Circ. Physiol. 10): H829-H837, 1981.

Burrows, M.E., and P.C. Johnson. Arteriolar responses to elewation of venous and arterial pressures in cat mesentery. Am. J. Physiol. 245 (Heart Circ. Physiol. 14); H796-H807, 1983.

Burton, A.C. Physiology and biophysics of the circulation (2nd ed.). Chicago, Year Book Medical Publishers, Inc., 1972, p. 86-94.

Burton, K.S., and P.C. Johnson.. Reactive hyperemia in individual capillaries of skeletal muscle. Am. J. Physiol. $223: 517-524,1972$.

Burton, K.S. Cat sartorius muscle: an isolated perfused skeletal muscle preparation for microvascular research. Microvasc. Res. 5: 401-409, 1973.

Busse, R. U. Förstermann, H. Matsuda, and U. Pohl. The role of prostaglandins in the endothelium-mediated vasodilatory response to hypoxia. Pflüg. Arch. 401: 77-83, 1984.

Chambers, R., and B.W. Zweifach. Functional activity of the blood capillary bed, with special reference to visceral tissue. Annals NY Acad. Sci. 46: 683-695, 1945. 
Chen, LI,H. R.L. Prewitt, and R.F. Dowell. Microvascular rarefaction in spontaneously hypertensive rat cremaster musle. Am. J. Physiol. 241 (Heart Circ. Physiol. 10): H306-H310, 1981.

Colantuoni, A, S. Bertuglia, and M. Intaglictta Quantitation of rhythmic diameter changes in arterial microcirculation. Am. J. Physiol. 246 (Heart Circ. Physiol. 15): H508-H517, 1984.

Colantuoni, $A_{\alpha}$ S. Bertuglia, and M. Intaglietta. The effects of $\alpha$ - or $\beta$-adrenergic receptor agonists and antagonists and calcium entry blockers on the spontancous vasomotion. Microvasc. Res. 28: 143-158, 1984

Collantuoni, A., S. Bertuglia, and M. Intaglietta. Effects of anesthesia on the spontaneous activity of the microvasculature. Int. J. Microcirc.: Clin. Exp. 3: 13-28, $1984^{\text {C. }}$

Colantuoni, A.s. Bertuglia, and M. Intaglietta. Microvessel diameter changes during hemorrhagic shock in unanesthetized hamsters. Microvasc. Res. 30: 133-142, 1985 .

Collantuoni, A., S. Bertuglia, and M. Intaglietta. Variations of rhythmic diameter changes at the arterial microvascular bifurcations. Pflüg. Arch. 403: 289-295, $1985^{\circ}$.

Damon, D.H, and B.R. Duling. Distribution of capillary blood flow in the microcirculation of the hamster: An in wivo study using epifluorescent microscopy. Microvasc. Res. 27: 81-95, 1984.

Damon, D.H., and B.R. Duling. Evidence that capillary perfusion heterogeneity is not controlled in striated muscle. Am. J. Physiol. 249 (Heart Circ. Physiol. 18): H386 H392, 1985.

Dawant, B. M. Levin, and A.S. Popel. Effect of dispersion of wessel diameters and lengths in stochastic networks. Microvasc. Res. 31: 203-222, 1986.

Dawsson, J.M., K.R. Tyler, and O. Hudlická. A comparison of the microcirculation in rat fast glycolytic and slow oxidlative muscles att rest and during contractions. Microvasc. Res. 33: 167-182, 1987.

Duling B.R., I.H. Sarelius, and W.F. Jackson. A comparison of microwascular estimates of capillary blood flow with direct measurement of total striated muscle flow. Int. J. Microcirc.. Clin. Exp. 1: 409-424, 1982.

Duling, B.R., and D.H. Damon. An examination of the measurement of flow heterogeneity in striated muscle. Circ. Res. 60: 1-13, 1987.

Duran, W.N. Effects of muscle contraction and of adenosine on capillary transport and microvascular flow in dog skeletal muscle. Cire. Res. 41: 642-647, 1977.

Ellsworth, M.L., A. Liu, B. Dawant, A.S. Popel, and R.N. Pittman. Analysis of vascular pattern and dimensions in arteriolar networks of the retractor muscle in young hamsters. Microvasc. Res. 34: 168-183, 1987.

Elmore, M.D., and P.C. Johnson. Compatible multiplex closed-circuit television and analog data recording. Microvasc. Res. 23: 385-391, 1982.

Engelson, E.T., G.W. Schmid-Schönbein, and B.W. Zweifach. The microvasculature in skeletal muscle. III. Venous network anatomy in normotensive and spontaneously hypertensive rats. Int. J. Microcire.: Clin. Exp. 4: 229-248, 1985.

Eagelson, E.T., T.C. Skalak, and G.W. Schmid-Schönbein. The microwasculature in skeletal muscle. I. Arteriolar network in rat spinotrapezius muscle. Microvasc. Res. 30: 29-44, $1985^{\text {b. }}$.

Engelson, E.T., G.W. Schmid-Schônbein, and B.W. Zweifach. The microvasculature in skeletal muscle. II. Arteriolar network anatomy in normotensive and spontaneously hypertensive rats. Microvasc. Rees. 31: 356$374,1980$.

Eriksson, $E_{\text {, and }}$ B. Lisander. Changes in precapillary resistance in skeletal muscle vessels studied by intravital microscopy. Acta Physiol. Scand. 84: 295-305, 1972.

Eriksson, E. and R. Myrhage. Microwascular dimensions and blood flow in skeletal muscle. Acta Physiol. Scand., 84: 211-222, 1972.

Faber, J.E., P.D. Harris, and F.N. Miller. Microvascular sensitivity to $\mathrm{PGE}_{2}$ and $\mathrm{PFI}_{2}$ in skeletal muscle of decerebrate rat. Am. J. Physiol, 243 (Heart Circ. Physiol. 12): H844-H851, 1982

Falber, J.E., P.D. Harris, and D.L. Wiegman. Anesthetic depression of microcirculation, central hemodynamics, and respiration in decerebrate rats. Am. J. Physiol. 243 (Heart Circ. Physiol. 12): H837-H843, 1982.

Faber, J.E., P.D. Harris, and I.G. Joshua. Microvascular response to blockade of prostaglandin synthesis in rat skeletal muscle. Am. J. Physiol. 243 (Heart Circ. Physiol. 12): H51-H60, 1982

Fagrell, B, M. Intaglietta, and J. Östergren. Relative hematocrit in human skin capillaries and its relation to capillary flow velocity. Microwase. Res. 20: 327.335, 1980.

Fagrell, B. Capillary dynamies in man. Prog. Appl. Microcirc. 3: 119-131, 1983. 
Folkow, B. Transmural pressure and vaseular tone-some aspects of an old controwersy. Arch. int: Pharmacodyn. 89: 455-469, 1962.

Folkow, B. Description of the myogenic hypothesis. Circ, Res. 15 (Suppl, 1): 279-287, 1964.

Funk, W., B. Endrich, K. Messmer, and M. Intaglietta. Spontaneous arteriolar vasonotion as a deterininant of peripheral vascular resistance. Int. J. Microcirc: Clin. Exp. 2: 11-25, 1983.

Funk, W., and M. Intaglietta. Spontaneous arteriolar vasomotion. Prog. Appl. Microcirc. 3: 66 82, 1983.

Gorcynnki, R. $J_{3}$ B. Klitzman, and B.R. Duling. Interrelations between contracting striated muscle and precapillary microvessels. Am. J. Physiol. 235 (Hetart Circ. Physiol. 4): H494-H504, 1978.

Grände, P.-O., J. Lundvall, and S. Mellander. Evidence for a rate-sensitive regulatory mechanism in myogenic microvascular control. Acta Physiol. Scand. 99: 432-447, 1977.

Grände, $P . \sim O$, and S. Mellander. Characteristics of static and dynanic regulatory mechanistans in myogenic microvascular control. Acta Physiol. Scand. 102: 231-245, 1978.

Granger, H.J., A.H. Goodman, and D.N. Granger. Role of resistance and exchange vessels in local microvascular control of skeletal muscle oxygenation in the dog. Circ. Res. 38: 379-385, 1976.

Granger, H.J., and A.P. Shepherd. Dynamics and control of the microcirculation. Adv. Bioned. Eng. 7: 1-63, 1979.

Granger, H.J., G.A. Meininger, J.L. Borders, R.J. Morff, and A.H. Goodman. Microcirculation of skeletal muscle. In: The physiology and pharmacology of the microcirculation 2, edited by NA. Mortillaro. Orlando, Academic Press. Inc., 1984.

Gray, S.D., P.F. McDonagh, and R.W. Gore. Comparison of functional and total capillary densities in fast and slow muscles of the chicken. Pflüg. Arch. 397: 209-213, 1983.

Greene, A.S., P.J. Tonellato, J.Z. Liu, and M.J. Davis. Microvascullar network stability studied in a mathematical model of the bat wing. The FASEB Journal 2: M67, 1988.

Greensmith, J.E. and B.R. Duling. Morphology of the constricted arteriolar wall: plrysiological implications. Am. J. Physiol. 247 (Heart Circ. Physiol. 16): H687-H698, 1984.

Hester, R.L., A.C. Guyton, and BJ. Barber. Reactive and exercise hyperemia during high levels of adenosine infusion. Am. J. Physiol. 243 (Heart Circ. Physiol. 12): H181-H186, 1982.

Honig, C.R., C.L. Odoroff, and J.L. Frierson. Capillary recruitment in exercise: rate, extent, uniformity, and relation to blood flow. Am. J. Physiol. 238 (Heart Circ. Physiol. 7): H31-H42, 1980.

Honig, C.R., and T.E.J. Gayeski. Correlation of $\mathrm{O}_{2}$ transport on the micro and macro scale. Int. J. Microcirc.: Clin. Exp. 1: 367-380, 1982.

Honig, C.R., C.L. Odoroff, and J.L. Frierson. Active and passive capillary control in red muscle at rest and in excersise. Am. J. Physioll. 243 (Heart Circ. Physiol, 12): H196-H.206, 1982.

Hudlicka, O., B.W. Zweifach, and K.R. Tyler. Capillary recruitment and flow velocity in skeletal muscle after contractions. Microvasc. Res. 23: 201-213, 1982.

Hudlickr, $O$., and $F$, el Khelly. Metabolic factors involved in regulation of muscle blood flow, J. Cardiovasc. Pharmacol. 7 (suppl.3): S59-S72, 1985.

Hundley, W.G., G.J. Renaldo, J.E. Levasseur, and H.A. Kontos. Vasonotion in cerebral microcirculation of awake rabbits. Am. J. Physiol. 254 (Heart Cïr. Physioll. 23): H67-H71, 1988.

Hutchins, P.M., R.F. Bond, and H.D. Green. Participation of oxygen in the local control of skeletal muscle microvasculature. Circ. Res. 34: 85-94, 1974.

Intaglietta, M., and W.R. Tompkins. Microvascullar measurements by video image shearing and splitting. Microvasc. Res. 5: 309-312, 1973.

Intaglietta, M. Vasomotor activity, time-dependent fluid exchange and tissue pressure. Microvasc. Res. 21: 153-164, 1981 .

Intaglietta, M., and J.F. Gross. Vasomotion, tissue fluid flow and the formation of lymph. Int. J. Microcirc.: Clin. Exp. 1: 55-65, 1982.

Intaglietta, M. Wave-like characteristics of vasomotion. Prog. Appl. Microcirc. 3: 83-94, 1983.

Johansson, $B_{3, \text { and }}$ S. Mellander. Static and dynamic components in the vascular myogenic response to passive changes in length as revealed by electrical and mechanical recordings from the rat portal vein. Circ. Res. 36: 76-83, 1975. 
Johansson, B, and A.F. Sonlyo. Electrophysiology and excitation-contraction coupling. In: Handbook of Physiology: The cardiavascular system II, edited by D.F. Bohr, A.P. Somlyo, and H.V. Sparks. Bethesda, American Physiological Society, 1980, p. 301-325.

Johnson, P.C., K.S. Burton, H. Henrich, and U. Henrich. Effect of occlusion duration on reactive hyperemia in sartorius muscle capillaties. Am. J. Physiol. 230: 715-719, 1976.

Johnson, P.C. Peripheral circulation. New York, John Wiley and Sons publishers, 1978.

Johnson, P.C. The myogenic response. In: Handbook of Physiology. The cardiovascular system $I$, edited by D.F. Bohr, A.P. Somlyo, and H.V. Sparks. Bethesda, American Physiological Society, 1980, p. 409-442.

Johnson, P.C. Autoregulation of blood flow. Circ. Res. 59: $483-495,1986$

Kayar, S.R., and N. Banchero, Sequential perfusion of skeletal muscle capillaries. Microvasc. Res, 30: 298* $305,1985$.

Klabunde, R.E., and P.C. Johnson. Reactive hyperemia ir capillaries of red and white skeletal muscle. Am. J. Physiol. 232 (Heart Circ. Physiol. 1): H411.H417, 1977 .

Klabunde, R.E, and $\mathrm{P}$.C. Johnson, Capillary velocity and tissue $\mathrm{pO}_{2}$ changes during reactive hyperemia in skeletal muscle. Am. J. Physiol. 233 (Heart Circ. Physiol. 2): H379-H383, $1977^{\text {b }}$.

Klabunde; R.E. Effects of dipyridamole on postischemic vasodilation and extracellular adenosine. Am. J. Plyysiol. 244 (Heart Circ. Physiol. 13): H273-H280, 1983.

Klabunde R.E. Attenuation of reactive and active hyperemia by sympathetic stimulation in dog gracilis muscle. Am. J. Physiol. 251 (Heart Circ. Physiol. 20); H1183-H1187, $1986^{\text {ä. }}$

Klabunde, R.E. Conditions for dipyridamole potentiation of skeletal muscle active hyperemia. A.m. J. Physiol. 250 (Heart Circ. Physiol. 19): H62-H67, 1986 ${ }^{\text {b }}$.

Klitzman, B., and P.C. Johnson. Capillary network geometry and red cell distribution in hamster cremaster muscle. Am. J. Physiol. 242 (Heart Circ. Physiol. 11): H211-H219, 1982.

Koller. A., B. Dawant, A. Liu, A.S. Popel, and P.C. Johnson. Quantitative analysis of arteriolar network architecture in cat sartorius muscle. Am. J. Physiol. 253 (Heart Circ. Physiol. 22): H154-H164, 1987.

Kuriyama, H., Y. Ito, H. Suzuki, K. Kitamura, and T. Itoh. Factors modifying contraction-relaxation cycle in vascular smooth muscles. Am. J. Physiol. 242 (Heart Circ. Physiol.12): H641-H662, 1982.

Krogh, A. The supply of oxygen to the tissues and the regullation of the capillary circulation. J. Physiol. (London) 52: 457-474, 1919.

Lewis, D.H. The response of microvasculature in skeletal muscle to hemorraghe, trauma and ischemia. Prog. Appl. Microcirc. 5: 127-138, 1984.

Ley, K., L. Lindbom, and K.-E. Arfors. Haematocrit distribution in rabbit tenuissimus muscle. Acta Physiol. Scand. 132: 373-383, 1988.

Lindbom, L, R.F. Tuma, G. Rutili, and $K_{0}$-E. Artors. Microvascular response of the tenuissimus muscle to manipulative trauma. Bibl. Anat. 15: 506-507, 1977.

Lindbom, $\mathbb{L}$, R.F. Tuma, and K.-E. Arfors. Influence of oxygen on perfused capillary density and capillary red cell velocity in rabbit skeletal muscle. Microvasc. Res. 19: 197 208, 1980.

Lindbom, L, R.F. Tuma, and K.-E. Arfors. Blood flow in the rabbit tenuissimus muscle. Inftuence of preparative procedures for intravital microscopic observation. Acta Physiol. Scand. 114: 121-127, 1982.

Lindbom, Lu, and K.-E. Arfors. Non-homogeneous blood flow distribution in the rabbit tenuissimus muscle; differential control of total blood flow and capillary perfusion. Acta Physiol. Scand. 122: 225-233, 1984.

Lindbom, $L_{\text {., and K. }} \mathbb{E}$. Arfors. Mechanisms and site of control for variation in the number of perfused capillaries in skeletal muscle. Int. $J$. Microcirc.: Clin. Exp. 4: 19-30, 1985.

Lindbom, L. Distribution patterns of blood flow in the rabbit tenuissimus muscle in response to brief ischemia and muscular contraction. Microvasc. Res. 31: 143-156, 1986.

Lund, N., D.H. Damon, D.N. Damon, and B.R. Duling. Capillary grouping in hamster tibialis anterior muscles: flow patterns and physiological significance. Int. J. Microcirc: Clin. Exp. 5: 359-372, 1987.

McDonagh, P.F., R.W. Gore, and S.D. Gray. Perfused capillary surface area in postural and locomotor skeletal muscle. Microvasc. Res, 24: 142-157, 1982.

Meininger, G.A., C.A. Mack, K.L. Fehr, and H.G. Bohlen. Myogenic vasoregulation overrides local metabolic control in resting rat sketetal muscle. Circ. Res. 60: 861-870, 1987 
Meininger, $G_{n}$ A. Responses of sequentially branching macro- and microversels during reactive hyperemia in skeletal muscle. Microvasc. Res. 34: 29-45, $1987^{b}$.

Mellander, S., and S. Arvidsson. Possible "dynamic" component in the myogenic wascular response related to pulse pressure distension. Acta Physiol. Scand. 90: 283-285, 1974.

Messina, EJ., R. Weiner, and G. Kaley. Arteriolar reactive byperemia: modification by inhibitors of prostaglamdin synthesis. Am. I. Physiol. 232 (Heart Circ. Physiol. 1: H571-H575, 1977.

Meyer, J,-U., L. Lindbom, and M. Intaglietta. Coordinated dianeter oscillations at arteriolar bifurcations in skeletal muscle. Am. J. Plyysiol. 253 (Heart Circ. Physiol. 22): H568-14573, $1987^{\text {a }}$.

Meyer, J.U, L. Lindbom and M. Intaglietta. Pacemaker induced diameter oscillations at arteriolar bifurcettions in skeletal muscle. Prog. appl. Microcirc. 12:264-269; 1987".

Meyer, J.-U., P. Borgström, L. Lindbom, and M. Intaglietta. Vasomotion patterns in skeletal muscle arterioles during changes in arterial pressure. Microvasc. Res. 35: 193-203, 1988.

Meyer, J.-U. Control and analysis of arteriolar vasomotion. Thesis, Univ, of Calie, San Diego, U.S.A, $1988^{\text {b. }}$.

Mirhashemi, S., K. Messmer, K.E. Arfors, and M. Intaglietta. Microcirculatory effects of mormowolemic hemoditution in skeletal muscle. Int. J. Microcirc.: Clin. Exp. 6: 359-369, 1987.

Morff, R.I., and H.J. Granger. Autoregulation of blood tlow within andividual arterioles in the rat cremaster muscle. Circ. Res. 51: 43-55, 1982.

Morff, R.J., and H.J. Granger. Contribution of actenosine to arteriolar autoregulation in striated muscle. Arn. J. Playsiol. 244 (Heart Circ. Physiol. 13): H567-H576, 1983.

Myrhage, $R_{n}$ and $O$. Hudlická. The microvascular bed and capillary surface area in rat extensor hallucis proprius muscle (EHP). Microvasc. Res. 11: 315-323, 1976.

Myrhage, $R$, and $O$. Hudlická. Capillary growth in chronically stimulated adult skeletal muscle as studied by intravital microscopy and histological methods in rabbits and rats. Microvasc. Res. 16: 73-90, 1978.

Myrhage, R.y and E. Eriksson. Arrangement of the vascular bed in different types of skeletal muscles. Prog. Appl Microcirc. 5: 1-14, 1984.

Nicoll, P.A., and R.I. Webb. Vascular patterns and active vasomotion as determiners of flow through minute vessels. Angiology 6: 291-308, 1955.

Öhlen, A., L. Lindbom, W. Staines, T. Hökfelt, A.C. Cuello, J.A. Fischer, and P. Hedqvist. Substance P and calcitonin gene-related peptide: inmunohistochemical localisation and microvascular effects in rabbit skeletal muscle. Naunyn-Schmiedeberg's Arch. Pharmacol. 336:87-93, 1987.

Osol, G., and W. Halpern. Spontaneous vasomotion in pressurized cerebral arteries from genetically hypertensive rats. Am. J. Physiol. 254 (Heart Circ. Physiol. 23): H28-H33, 1988.

Pittman, R.N. Influence of oxygen lack on vascular smooth muscle contraction. In: Vasodilation, edhted by P.M. Vanhoutte and I. Leusen. New York, Rawen Press, 1981.

Pittman, R.N. Interaction between oxygen and the blood vessel wall. Can. J. Cardiol. 2: 124-131, 1986.

Pittman, R.N., and M.L. Ellsworth. Estimation of red cell flow in microvessels: consequences of the BakerWayland spatial averaging model. Microvasc. Res. 32: 371-388, 1986.

Pohl, U., R. Busse, E. Kuon, and E. Bassenge. Pulsatile perfusion stimulates the release of endothelial autacoids. J. appl. Cardiol. 1: 215-235, 1986.

Pohl, U., L. Deessi, B. Simon, and R. Busse. Selective inhibition of endothelium-dependent dilation in resistance-sized vessels in vivo. Am. J. Physiol. 253 (Heart Circ. Physiol, 22): H234-H239, 1987.

Potter, R.F., and A.C. Groom. Capillary diameter and geometry in cardiac and skelletal muscle studied by means of corrosion casts. Microvasc. Res. 25: 68-84, 1983.

Prewitt, R.L., and P.C. Johnson. The effect of oxygen on arteriolar red cell velocity and capillary density in the rat cremaster muscle. Microvasc. Res. 12*59-70, 1976.

Prewit, R.L., L.I.H. Chen, and R. Dowell. Development of microvascular tarefaction in the spontancously hypertensive rat. Am. J. Physiol. 243 (Heart Circ. Physiol, 12): H243-H251, 1982.

Prinzen, F.W., R. Alewijnse, G.J. van der Vusse, R.T.I. Kruger, T. wan de Nagel, and R.S. Renematu. Coronary artery stenosis controlled by distal perfusion pressure: description of the servo-system and time-dependent changes in regional myocardial blood flow. Basic Res. Cardiol. 82: 375-387, 1987. 
Proctor, K.G., and B.R. Duling Adenosine gad free-flow functional hyperemia in striated muscle. Am J. Physiol. 242 (Heart Circ. Physiol. 11): H688-H697, 1982.

Reneman, R.S. D.W. Slaaf, L. Lindbom, G.J. Tangelder, and K. E. Arfors. Muscle blood llow disturbances produced by simultaneously elevated venous and total muscle tissue pressure. Microvasc. Res. 20: 307$318,1980$.

Renkin, E.M., S.D. Gray, and L.R. Dodd. Filling of microcirculation in skeletal muscles during timed India ink perfusion. Am. J. Physiol. 241 (Heart Circ. Physiol. 10): H174-H186, 1981.

Renkin, E.M. Control of microcirculation and blood-tissue exchange. In: Handbook of Physiology: The cardiovascular system IV, edited by E.M. Renkin, and C.C. Michel. Bethesda, American Physiological Society, 1984, p. 627-689.

Rutilli, $G_{i}$ and $K_{t}-E$. Arfors. Measurement of blood flow in the tenuissimus muscle with tracer sephadex. Microvasce Res. 11: 269-274, 1976.

Sarelius, I.H, D.N. Damon and B.R. Duling. Microvascular adaptions during maturation of striated muscle. Am. J. Physiol. 241 (Heart Circ. Physiol. 10): H317-H324, 1981.

Shibata, M., and A. Kamiya. Microcirculatory responses to carotid sinus nerve stimulation at various ambient $\mathrm{O}_{2}$ tension in the rabbit tenuissimus muscle. Microvasc. Res. 30: 333-345, 1985.

Siegel G. Principles of vascular rhythmogenesis. Prog. appl. Microcirc. 3: 40-62, 1983.

Skalak, T.C., G.W. Schmid-Schönbein, and B.W.Zweifach. New morphological evidence for a mechanism of Iymph formation in skeletal muscle. Microvasc. Res. 28: 95-112, 1984.

Skalak, T.C., and G.W. Schmid-Schömbein. The microvasculature in skeletal muscle. IV. A model of the capillary network. Microvasc. Res. 32: 333-347, 1986.

Slaaf, D.W., R. Alewijnse, and H. Wayland. Use of telescopic imaging in intravital microscopy: a simple solution for conventional microscopes. Int. J. Microcirc: Clin. Exp.: 1, 121-134, 1982.

Slaaf, D.W., G.J. Tangelder, H.C. Teirlinck, and R.S. Reneman. Arteriolar vasomotion and arterial pressure reduction in rabbit tenuissimus muscle. Microvasc. Res. 33: 71-80, $1987^{\mathrm{a}}$.

Slatil, D.W., R.S. Reneman, and C.A. Wiederhielm. Pressure regulation in muscle of unanesthetized bats. Microvasc. Res. 33: 315-326, 1987 .

Sullivan, S.M., and P.C. Johnson. Effect of oxygen on blood flow autoregullation in cat sartorius muscle. A.m. J. Physiol. 241. (Heart Circ. Physiol 10): H807-H815, 1981 ${ }^{\mathrm{a}}$.

Sullivan, S.M., and P.C. Johnson. Effect of oxygen on arteriolar dimensions and blood flow in cat sartorius muscle. Am. J. Physiol. 241 (Heart Circ. Physiol, 10): H547-H556, 1981 .

Sullivan, S.M., and R.N. Pittman. Hamster retractor muscle: a new preparation for intravital microscopy. Microvasc. Res. 23: 329-335, 1982.

Sullivan, S.M., and R.N. Pittman. In vitro $\mathrm{O}_{2}$ uptake and histochemical fiber type of resting hamster muscles. J. Appl. Physiol. 57: 246-253, 1984.

Swain, D.P. and B.J. Lalono. Rat graciliss tnuscle preparation for combined macro- and microvascular research. Am. J. Physiol. 242 (Heart Circ. Physiol. 11): H713-H721, 1982.

Tangelder, G.J., D.W. Slat, and R.S. Reneman. Skeletal muscle microcirculation and changes in transmural and perfusion pressure. Prog. Appl. Microcirc. 5: 93-108, 1984.

Tesfamariam, $B_{w}$ and W. Halpern. Modulation of adrenergic responses in pressurized resistance arteries by flow. Am. J. Physiol. 253 (Heart Circ. Ptysiol. 22): H1112-H1119, 1987.

Thiompson, L.P., and D.E. Mohrman. Blood flow and oxygen consumption in skeletal muscle during sympathetic stimulation. Am. J. Physiol. 245 (Heart Circ. Physiol. 14): H66-H71, 1983.

Tuma, R.F., L. Lindbom, and K.-E. Arfors. Dependence of reactive hyperemia in skeletal muscle on oxygen tension. Am. J. Physiol. 233 (Heart Circ. Physiol. 2): H289-H294, 1977.

Tyml, K., C.G. Ellis, R.G. Safranyos, S. Fraser, and A.C. Groom. Temporal and spatial distributions of red cell velocity in capillaries of resting skeletal muscle, including estimates of red cell transit times. Microvasc. Res. 22: 14-31, 1981.

Tyml, K. Capillary recruitment and heterogeneity of mïcrovascular flow in skeletal muscle before and after contraction. Microvasc. Res. 32: 84-98, 1986. 
Tyml, K. Red cell perfusion in skeletal muscle at rest and after mild and severe contractions. Am. J. Physiol. 252 (Heart Circ. Physiol. 21): H485-H493, 1987.

Vetterlein, $F$, and $G$. Schmidt. Functional capillary density in skeletal muscle during vasodilation induced by isoprenaline and muscular exercise. Microvasc. Res. 20: 156-164, 1980.

Vicaut, E., O.Stucker, B. Teisseire, and M. Duvelleroy. Effects of changes in systemic hematocrit on the microcirculation in rat cremaster muscle. Int. J. Microcirc.: Clin. Exp. 6. 225-235, 1987.

Wayland, H., and P.C. Johnson. Erythrocyte velocity measurement in microvessels by a two-slit photonetric method. J. Appl. Physiol. 22: 333-337, 1967.

Wuedeman, M.P., R.F. Tuma, and H.N. Mayrovitz. An introduction to microcirculation. New York, Acadenic Press, 1981.

Wiederhielm, C.A., and D.W. Slaaf. A new skeletal muscle preparation for the study of microvascular function in intact unanesthesized animals. Microvase. Res. 33: 413-416, 1987. 


\section{SUMMARY}

Perfusion of skeletal muscle capillaries varies largely in time (temporal heterogeneity), Rhythmic variations in the cliameter of the feeding arterioles, a phenomenon known as vasomotion, play an important role in the capillary flow heterogeneity. The pattern of vasomotion can be changed by externally applied stimuli. The consequences of the presence of vasomotion for tissue perfusion and the relation between the changes in vasomotion pattern and local skeletal muscle blood flow control are incompletely understood. It was the aim of the present study to gather insight into the phenomenon of vasomotion at different levels in the arteriolar bed and to investigate the relation between vasomotion and skeletal muscle blood flow regulation. To this end, we investigated:

- whether in a resting skeletal muscle preparation, showing vasomotion, all or only part of the functionally available microvessels are involved in the distribution of blood over the tissue, i.e. whether recruitment exists,

- the consequences of the presence of vasomotion for local arteriolar resistance,

- the changes in vasomotion pattern at different arteriolar levels during arterial pressure reduction, and their relation to muscle perfusion,

- the changes in vasomotion waveform during different interventions to obtain insight into the mechanisms of vasomotion control.

The studies were performed in situ on the tenuissimus muscle of young, urethane anesthetized rabbits, using intravital microscopy to visualize the microvascular bed. The microscopic images together with the various hemodynamic wariables were stored on. video tape and were analyzed off-line.

In the tenuissimus muscle a central artery and vein run parallel to the muscle fibers in the thickest part of the muscle. Transverse arterioles branch from the central artery and generally run into the fascia near the muscle where they form arteriolar-venular shunts. The first order side branches of these transverse arterioles divide several times before ending in true capillaries. Vasomotion is observed in the transverse arterioles and their first order side branches. Vasomotion in the latter is frequently of an off and on nature, the arterioles sometimes completely closing during part of the cycle. This 
results in rhythmically fluctuating flow in all downstream capillaries. The pronounced vasomotion may result in cessation of capillary flow for periods of a few seconds. Microvessels not perfused for longer periods of time are not observed. Capillary recruitment is found to be absent (chapter 4).

In chapter 5 , a method to assess the combined influence of mean arteriolar diameter, vasomotion amplitude and vasomotion waveform on the mean local arteriolar resistance is introduced. To this end, the effective vascular diameter, i.e. the diameter that a vessel without vasomotion would need to carry the same blood flow as the vessel with vasomotion, assuming the same pressure gradient over the vessel segment during both situations, is calculated. Model calculations on symmetric vasomotion patterns are compared with the vasomotion patterns obtained from transverse arterioles and first order side branches. Due to the variability of the actual vasomotion waveforms, approximation of the effective arteriolar diameter, using mean diameter, vasomotion amplitude and an assumed waveform, leads to erroneous results. Therefore, the effective vascular diameter should be calculated directly from the actual diameter tracings. Vasomotion in the first order side branches contributes substantially to the mean vascular resistance, whereas the contribution in the transverse arterioles is limited (chapter 6). During arterial pressure reduction vasomotion cycle length and amplitude increase concomitant with an increase in effective arteriolar diameter and the maximum diameter during vasomotion in both the transverse arterioles and the first order side branches. These changes are associated with a decrease in local blood flow and reduced velocity, a measure of wall shear rate, in both types of arterioles. The changes in the vasomotion parameters show limited correlations with local blood flow, reduced velocity, arterial pressure and effective diameter, indicating that it is unlikely that only one of these variables is responsible for the changes in the vasomotion pattern.

During local application of adenosine the effective arteriolar cliameter and the maximum diameter during vasomotion increase also, but vasomotion cycle length and amplitude change variably (chapter 7 ). These findings indicate that stretch of the arteriolar wall does not play a role in vasomotion control.

Also in chapter 7 , an analysis of the origin of the vasomotion waveform changes during arterial pressure reduction and adenosine application is given. At moderate pressure reductions and during adenosine application, cycle length changes are limited (less than $1.5 \mathrm{~s}$ ) and in the transverse arterioles result from changes in both the dilation and the constriction phase. In the first order side branches, however, the changes in cycle length are caused by prolongation of the dilation phase alone. Because the onsets of dilation always occur synchronously in transverse arterioles and first order side branches but the onsets of constriction do not, these findings are not compatible with the idea that vasomotion is a series of rhythmic contractions. Only at greatly reduced pressure levels, pronounced increases in vasomotion cycle length occur, which are caused by plateau formation in the dilation phase in both the transwerse arterioles and their first order side branches.

In conclusion, vasomotion is an important phenomenon in the origin of heterogeneity in capillary perfusion in the rabbit tenuissimus muscle. The pattern of vasomotion can 
be changed by arterial pressure reduction. During vasodilation, as induced by locally applied adenosine, the changes in the vasomotion pattern are inconsistent. However, the way in which vasomotion waveform changes of comparable magnitude are accomplished is similar during both stimuli, despite important differences in local blood flow and wall shear rate. The mechanisms controlling these changes are still incompletely understood. The widespread notion that vasomotion is a series of rhythmic constrictions, the frequency of which is controlled by a classical pacemaker, is not affirmed by the present findings. On the contrary, vasomotion seems to be a series of rhythmic dilations. 


\section{Chapter 11.}

\section{SAMENVATTING}

Meer dan $99 \%$ van de Nederlanders zullen bij het lezen van de titel wan dit proefschrift "Vasomotion en skeletspierdoorbloeding" niet weten wat ze zich hierbij moeten voor stellen. Schrikt u dus niet als het $u$ ook zo vergaat. Speciaal voor u wil ik in deze samenvatting trachten de titel alsmede de achtergrond hiervan te verklaren. Verder zal ik aangeven hoe het onderzoek is uitgevoerd, waarna een bespreking van de voornaamste resuitaten volgt.

\subsection{Inleiding}

Bloedsomloop. Om te beginnen een korte, algemene beschrijving van het bloed en de bloedsomloop. De voornaamste funktie van het bloed is transport van zuurstof naar, en van koolzuur vanaf de diverse weefsels in het lichaam. Gespecialiseerde cellen in het bloed, de rode bloedcellen, zorgen hiervoor. Zij nemen zo'n $40 \%$ van het totale bloedvolume in. Daarnaast komen witte bloedcellen voor, gespecialiseerd in de afweer tegen bacteriën en andere lichaamsvreemde stoffen, en bloedplaatjes welke een funktie hebben bij de stolling. Verder worden talloze stoffen via het bloed van en naar de weefsels getransporteerd (o.a. brandstof, bouw-en afvalstoffen, water, hormonen). Het bloed is voortdurend in beweging en wordt door het hart rondgepompt in een uitgebreid buizennet: het bloedvaatstelsel (figuur 11.1). Vanaf het hart ontspringen grote, stevige vaten (de slagaders of arteriën) die naar de weefsels toe vertakken in steeds kleinere vaten: de arteriolen. De kleinste vaatjes, de haarvaten of capillairen, hebben een zeer dunne wand zodat uitwisseling van de eerder genoemde stoffen tussen het bloed en de lichaamscellen hier heel gemakkelijk plaatsvindt. De afvoer wit de weefsels gebeurt eveneens eerst via kleine vaten (venulen), waarna via de grote aderen (venen) het bloed teruggevoerd wordt naar het hart. 


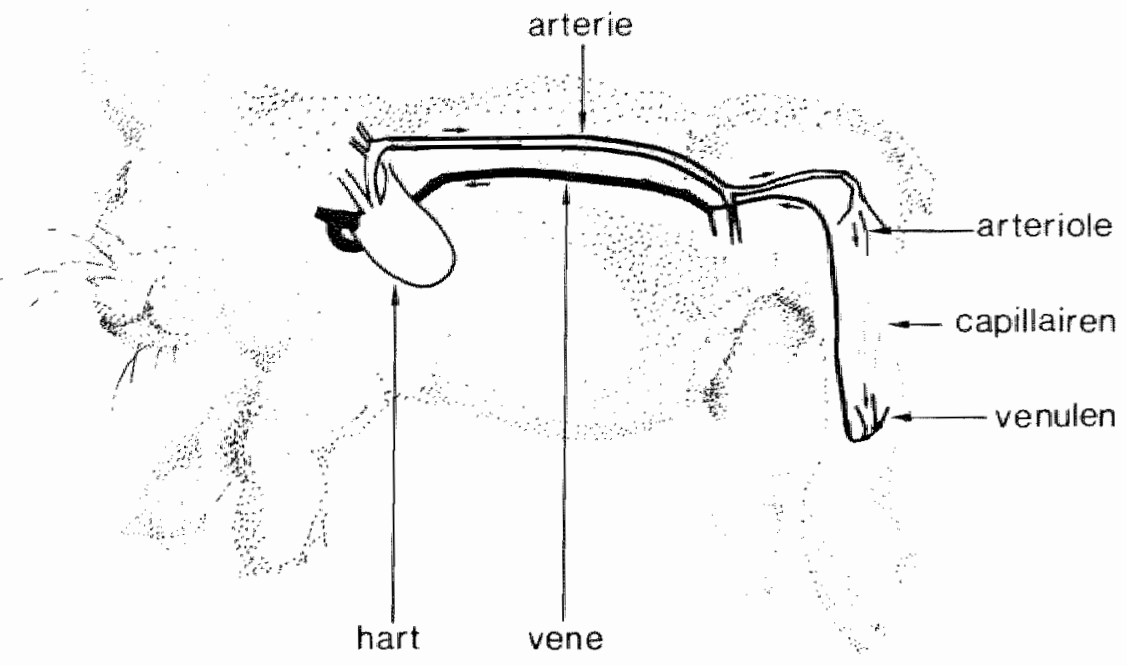

FGUUR 11.1: Alusstratie wan een deel wan het bloedwatstelsel wan een konijn. De pijilen geven de stroamrichting van het bloed aan.

Bloedvaten. Om het verhaal straks goed te kunnen begrijpen is het noodzakelijk eerst iets te weten over de opbouw wan de bloedvaten. Dit zal ik doen aan de hand van een stukje tiit de dwarsdoornsnede van een slagader (figuur 11.2). Voor de verschillen vaat typen is de opbouw in grote lijnen dezelfde. Van binnen naar buiten komen we achtereenvolgens tegen:

1. een endotheelcellaag, dit is een aaneengesloten laag cellen die de bloedvaten aan de binnenkant bedekt,

2. een elastisch membraan, een dun laagje elastisch bindweefsel,

3. een spiercellaag, voomamelijk bestaande uit circulair liggende spiercellen en hiertussen elastisch bindweefsel,

4. een bindweefsellaag, met hierin zowel elastisch als niet-elastisch bindweefsel.

Bij de haarvaten (capillairen) bestaat de wand uitsluitend uit een endotheelcellaag en een dunne laag bindweefsel. Deze laag is zo dun dat een aantal stoffen (waaronder zuurstof) zeer snel vanuit het bloed in het weefsel komen kan. Grote arteriën zoals de aorta bevatten veel elastisch bindweefsel. Dit is nodig om de grote druk bij iedere hartslag te kunnen opvangen. Kleine arteriën en de arteriolen bevatten een relatief dikke spiercellaag. Door de spiercellen hierin in meer of mindere mate samen te trekken kan een arterie of arteriole zijn diameter veranderen. Hierdoor verandert zijn weerstand 


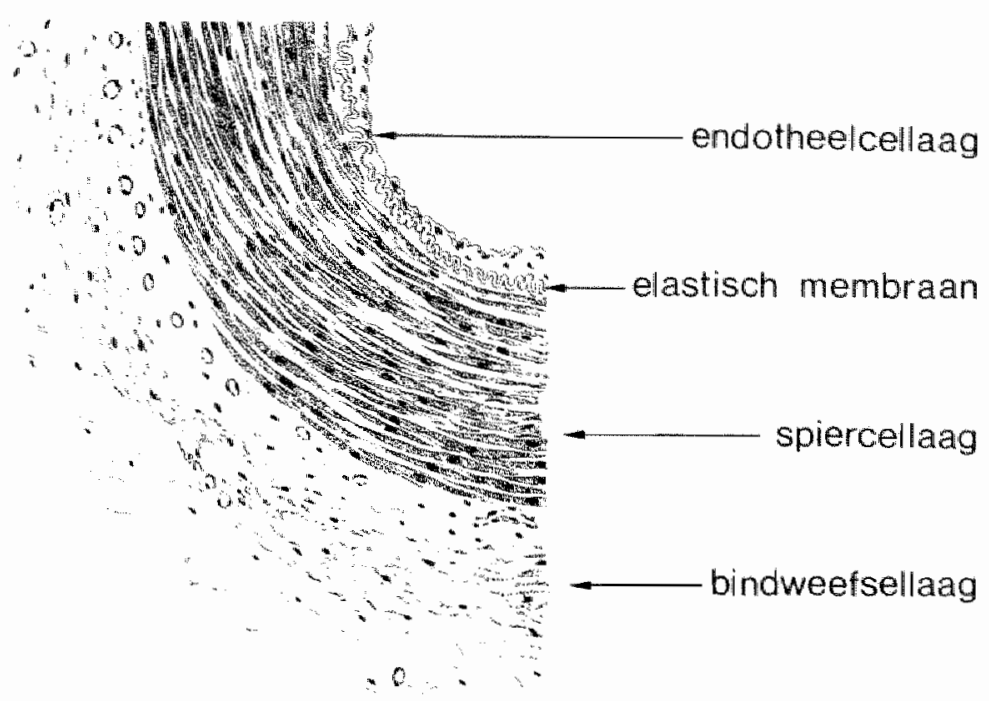

FIGUUR 11.2: Dwarsdoorsnede door de wand van een arterie.

voor de bloedstroom zodat de hoeveelheid bloed die door dat vat naar de achterliggende capillairen stroomt verandert. Met andere woorden, door de aanwezigheicl wan een spierlaag in de vaatwand zijn arteriën en arteriolen in staat de doorbloeding wan het achterliggende weefsel te regelen. Een voorbeeld ter illustratie: tijdens slaap zijn de meeste spieren van ons lichaam ontspannen en gebruiken weinig energie. De toevoer van brandstof en zuurstof via het bloed zal dan ook navenant laag zijn. Dit wordt bereikt door de diameter van de voedende arteriën en arteriolen sterk te verkleinen zodat nog maar weinig bloed passeren kan. Echter, worden de spieren aktief, dan zullen de bloedvaten verwijden om meer brandstof en zuurstof tot het weefsel toe te laten.

Regulering van de bloedstroom. Hierbij zijn wooral de kleine arteriën en arteriolen betrokken. Het mechanisme is complex: er zijn zeer veel stoffen en faktoren bekend die de mate van doorbloeding van skeletspieren kunnen beïnwloeden. Hiervan wil ik er hier slechts 2 noemen, orndat ik beide gebruikt heb tijdens de in dit boekje beschreven experimenten. Ten eerste de bloeddruk. Arteriolen hebben de neiging om hun diameter te verkleinen als de bloeddruk stijgt. Door een hogere druk zou er namelijk meer bloed dan noodzakelijk naar het weefsel stromen. Een kleinere diameter van de arteriolen voorkomt dit. Bij bloeddrukverlaging gebeurt het omgekeerde: de vaten verwijden om de geringere toevoer ten gevolge van de verlaagde bloeddruk te kompenseren. Deze neiging van arteriolen om door middel van diameterveranderingen de bloedstroom naar het weefsel konstant te houden ondanks veranderingen in de bloeddruk noemen we 'autoregulatie' (autos = zelf). Tijdens de verderop in dit hoofdstuk be- 


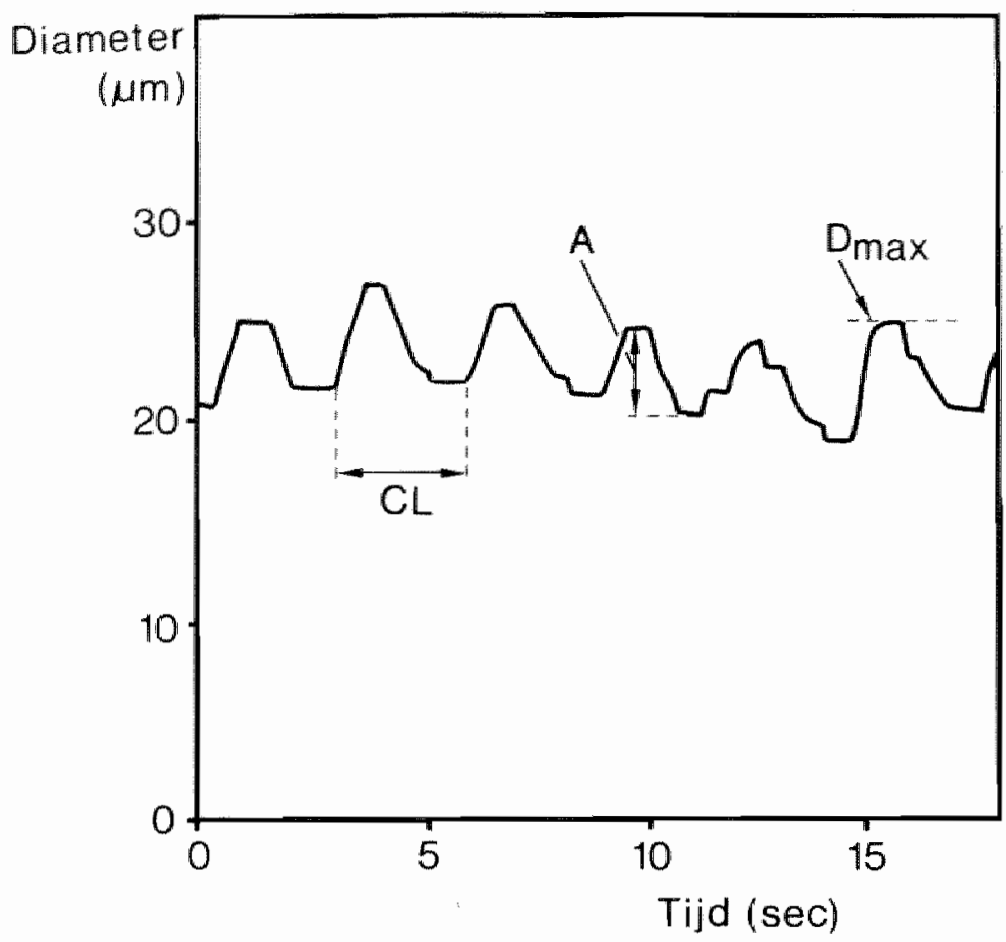

FIGUUR 11.3: Voarbeeld vax een wasomotionpatroon in een arteriole. Hierin zijn aangegeven de wasomotion cyclwstengte $(C L)$, vasomotion amplitude $(A)$ en de maximale diameter tijdens een vasomotion cyclus $\left(D_{\max }\right)$.

schreven experimenten heb ik bloeddrukverlaging toegepast en gekeken hoe de arteriolen hierop reageerden. Daarnaast heb ik geexperimenteerd met de stof 'adenosine'. Deze stof veroorzaakt verwijding van de arteriolen en zorgt, bij normale bloeddruk, voor een sterk vergrote bloedstroom naar het weefsel.

Vasomotion. Het eigenaardige van de arteriolen is dat hun diameter voortdurend ritmisch varieert. Dit verschijnsel heet in het engels 'vasomotion', en omdat er geen goed Nederlands woord voor bestaat wil ik het maar zo blijven noemen. Vasomotion wordt duidelijk als we de diameter van een arteriole gedurende een tijdje volgen: zie figuur 11.3. Veel over het hoe en waarom van vasomotion is nog onbekend. De studie, zoals beschreven is in dit boekje, is opgezet om meer inzicht te verkrijgen in het fenomeen vasomotion en de relatie van wasomotion met de doorbloeding van skeletspieren. 


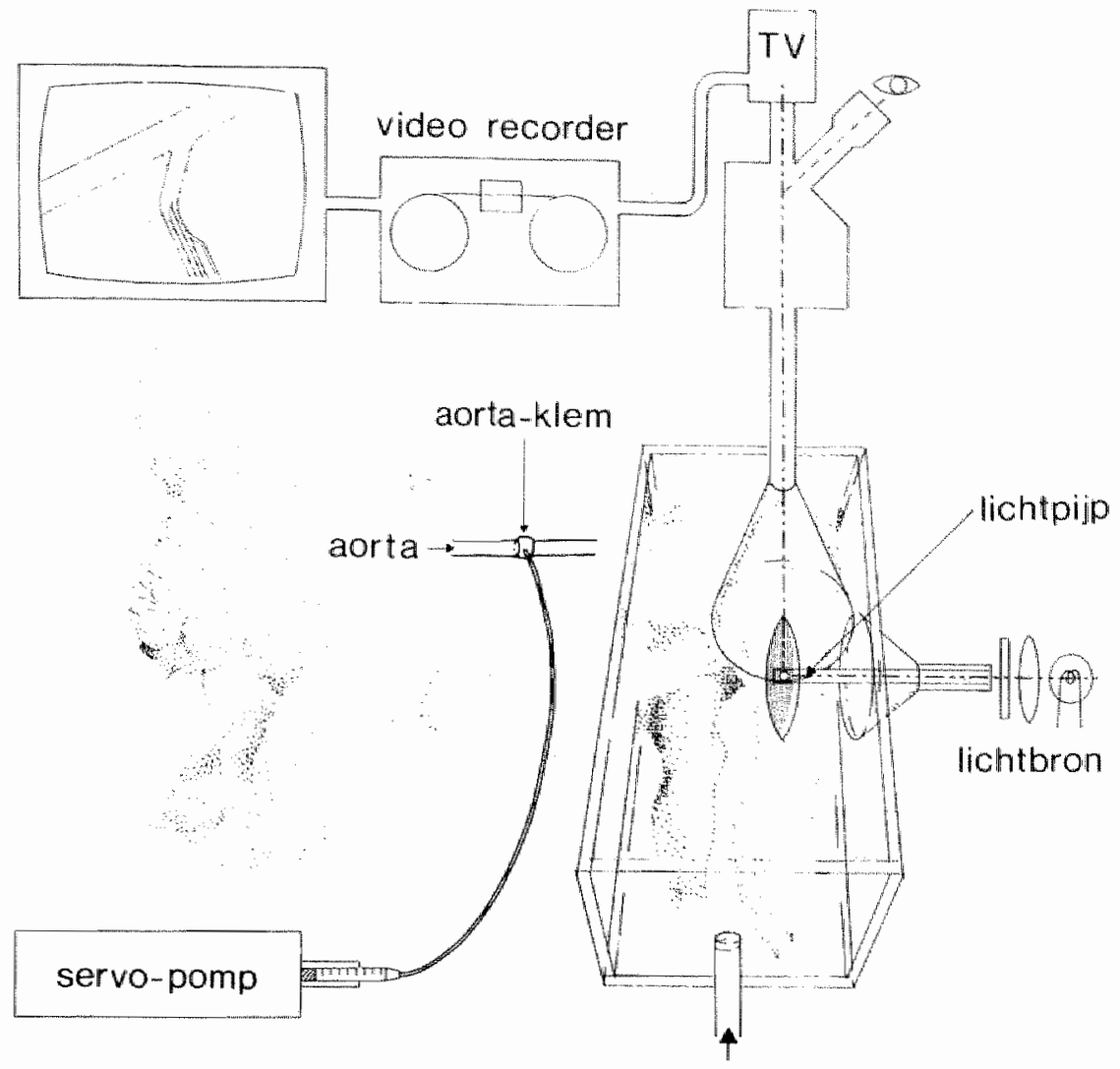

FIGUUR 11.4: Schematische weergave van de experimentele opstelling.

\subsection{Methoden}

De microscoop. De in dit proefschrift beschreven experimenten zijn gebaseerd op microscopische waarneming van bloedvaten in de tenuissimusspier van een konijn. De tenuissimusspier is een zeer dun spiertje gelegen in de achterpoot. Na totale verdoving van het dier en blootleggen van het spiertje werd de geopereerde poot in een gasdicht af te sluiten box vastgezet (zie figuur 11.4). Hiermee waren we in staat de omgeving van de tenuissimusspier relatief zuurstofarm te houden zodat de spier, voor zijn zuurstofvoorziening afhankelijk bleef van zijn eigen bloedvoorziening. Onder de 


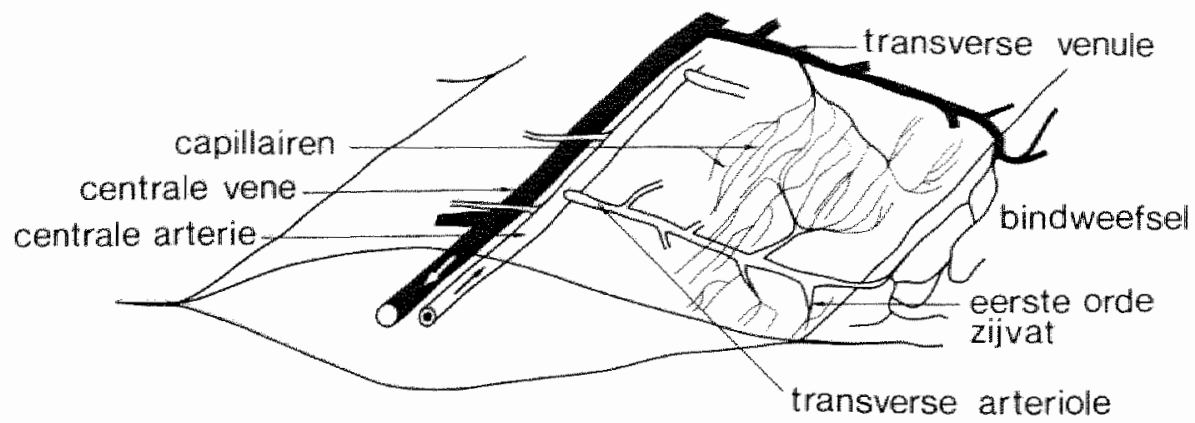

FIGUUR 11.5: Schematische tekening van her waatbed van de tenuissimusspier.

teruissimusspier werd een lichtpijp aangebracht om de spier van onderaf te belichten. Vervolgens werden konijn en box op de microscooptafel geplaatst, waarna de bloedvaten in de tenuissimusspier konden worden bekeken. Via een videokamera konden we de vaten zichtbaar maken op een televisiescherm. Tevens bood dit de mogelijkheid de beelden op videoband vast te leggen.

Het vaatbed. Het vaatbed van de tenuissimusspier ziet er schematisch als volgt uit (figuur 11.5): in het dikste gedeelte van de spier lopen een centrale arterie en vene parallel aan elkaar. De centrale arterie heeft diverse zijtakken: de transverse arteriolen. De kleine zijvaatjes van deze transverse arteriolen noemen we de eerste orde zijvaten. Deze vertakken diverse keren en voeden zo'n 20 tot 50 capillairen. Een deel van het bloed dat door de transverse arteriolen stroomt gaat niet naar de capillairen, maar naar het bindweefsel naast de spier. Via transverse venulen stroomt het bloed terug naar de centrale vene.

Vasomotion komt alleen voor in de transverse arteriolen en hun eerste orde zijvatem. De lengte van een vasomotioncyclus (zie figuur 11.3) bedraagt in beide typen vaten ongeveer 3 seconden. De amplitude van vasomotion (figuur 11.3) is in de transverse arteriolen in de orde van grootte van $5 \mu \mathrm{m}$. In de eerste orde zijvaten is de vasomotion amplitude waak groter en zelfs zo sterk dat deze vaten nu en dan volledig sluiten (figuur 11.6). Tijdens dit sluiten ligt de bloedstroom in de achterliggende capillairen volledig stil.

De experimenten. Bij ieder experiment werd een arteriole opgezocht en gedurende enkele minuten opgenomen op videoband (de controlesituatie). In een aantal experimenten werd vervolgens de bloedtoevoer naar de tenuissimusspier verlaagd door middel van een klem om de aorta (figuur 11.4). De klem was regelbaar door middel van een servo-pomp, zodat de bloeddruk in stapjes verlaagd kon worden. Bij iedere stap werd het gedrag van de arteriole wederom gedurende enkele minuten vastgelegd op videoband.

Tijdens een andere serie experimenten werd de vaatverwijder adenosine in stapsgewijs 


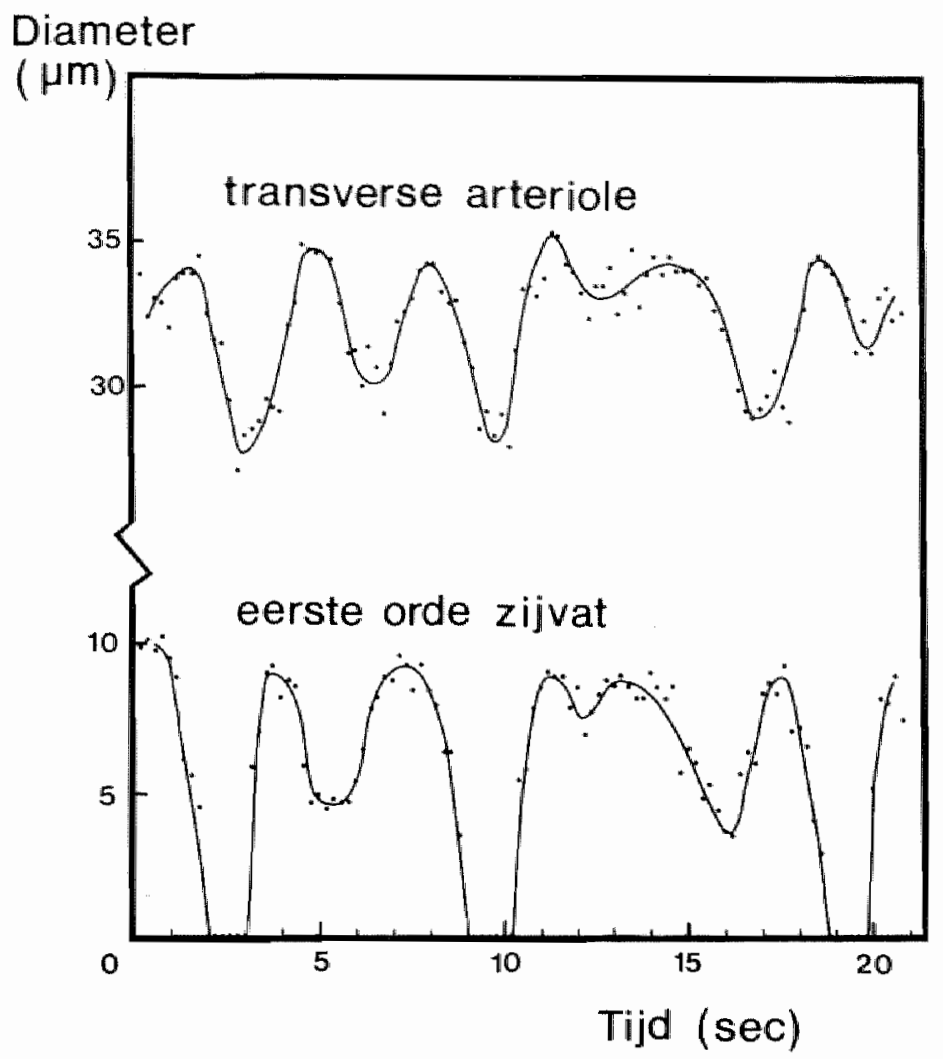

FIGUUR 11.6: Gelijktijdige vasomotionpatronen in een transwerse arteriole (bowen) er zijn eerste orde zijvat (onder).

oplopende concentraties op de tenuissimusspier gedruppeld. Ook hier werd bij iedere stap het gedrag van de arteriolen op videoband vastgelegd.

De analyse van de videobanden gebeurde na afloop van de experimenten. Hiertoe werden de opgenomen videobeelden vertraagd afgespeeld en werd de diameter van de desbetreffende arteriole gemeten. Voor deze diametermeting is een apparaat ontwikkeld waarmee het beeld van een beeldscherm dwars over een vat kon worden gesplitst, zodat de ene vaatwand tegenover de andere kon worden gezet (ter illustratie zie de voorkant van dit proefschrift). De verplaatsing van de twee beelddelen ten opzichte van elkaar is een maat woor de diameter van het vat, welke met een elektrische schrijver op papier werd vastgelegd. Enkele voorbeelden van zo'n registratie heb ik al laten zien in de figuren 11.3 en 11.6. Elk van de registraties werd geanalyseerd op diverse vasomotion parameters, onder andere de vasomotion cycluslengte (CL), de vasomotion amplitude $(A)$ en de maximale diameter tijdens vasomotion $\left(\mathrm{D}_{\max }\right.$ ). Deze parameters zijn aangegeven in figuur 11.3. 


\subsection{Resultaten}

Hopelijk zijn de achtergrond en de experimentele opzet van dit boekwerkje u een beetje duidelijk. Dan zal ik nu het onderzoek zelf bespreken.

Recruteren van bloedwaten. De eerste vraag die we onszelf stelden was, of alle aanwezige waten in de tenuissimusspier in rust meedoen aan de verdeling van het bloed over het spierweefsel, of dat maar een deel van de arteriolen en capillairen hierbij betrokken is (hoofdstuk 4). In het laatste geval zou het andere deel afgeslaten kunnen zijn en, zoals veel onderzoekers denken, alleen geopend worden als de behoefte aan bloed groter wordt, bijvoorbeeld tijdens inspanning. Bloedvaten worden dan als het ware gerecruteerd als daar behoefte aan is. Het huidige onderzoek toonde aan dat alle arteriolen en capillairem in de tenuissimusspier in rust doorstroomd zijn en dat dus als de behoefte aan bloed woor dit spiertje groter wordt, er dus geen extra bloedvaten gerecruteerd kunnen worden. Waarom deze resultaten afwijken van veel andere onderzoeken is niet geheel duidelijk. Mogelijk speelt hierbij de aanwezigheid van vasomotion in de tenuissimusspier een rol; zoals gezegd veroorzaakt de sterke vasomotion in de eerste orde zijvaten een wisselende doorstroming van de achterliggende capillairen. Met name tijdens het moment waarop deze zijvaten wijd open staan zal zó veel bloed passeren dat alle capillairen, zelfs de meest nauwe, doorstroomd zullen worden. Dit heeft geleid tot de gedachte dat de aanwezigheid van vasomotion in een vaatbed leidt tot een meer homogene verdeling van het bloed over alle aanwezige capillairen.

Invloed vasomotion op vaatweerstand. We vroegen ons af in welke mate de aanwezigheid van vasomotion in de arteriolen de doorstroming van die vaten en van de achterliggende capillairen beinvloedt. Met andere woorden, wat de invloed van vasomotion op de vaatweerstand is. "Ter verduidelijking: vergelijken we twee vaten met eenzelfde gemiddelde diameter, waarvan in én van beide vasomotion aanwezig is, dan heeft het vat met vasomotion gemiddeld minder weerstand dan het vat met konstante diameter. In dat geval zal de bloedstroom in het vat met vasomotion dus groter zijn. Hoeveel groter is niet zonder meer te zeggen. Om dit te kunnen schatten is in hoofdstuk 5 het begrip 'effectieve diameter' ingevoerd. Dit is de diameter die een vat mét vasomotion zou hebben gehad indien vasomotion afwezig was, om toch eenzelfde gemiddelde weerstand voor de bloedstroom te hebben. Met belmulp van deze effectieve diameter konden we de invloed van vasomotion op de weerstand vergelijken in waten met geheel verschillende vasomotion patronen vergelijken, zoals in de transverse arteriolen en hun eerste orde zijvaten.

In de eerste orde zijwaten heeft vasomotion een duidelijke invloed op de vaatweerstand. De aanwezigheid van vasomotion in deze vaten zorgt voor een wisselende doorstroming van de achterliggende capillairen. De gedachte is dat de eerste orde zijvaten zorgen woor de fijn-regulering van de bloedstroom binnen een beperkt spiergebied. 
In de transverse arteriolen van de tenuissimusspier bleek de vasomotion nauwelijks invloed te hebben op de gemiddelde weerstand, omdat de effectieve diameter nagenoeg gelijk bleek aan de gemiddelde diameter. Dit wil zeggen dat als er geen vasomotion in deze vaten zou zijn, de bloedstroom door die vaten toch ongeveer dezelfde zou blijven. Vasomotion in de transverse arteriolen speelt dus eigenlijk geen rol in de regulering van de bloedstroom naar het weefsel. De gedachte is dan ook dat de transwerse arteriolen zorgen voor de verdeling van bloed over relatief grote delen van een spier en alleen de grove regulering van de bloedstroom naar die spiergebieden regelen.

Veranderingen in het vasomotionpatroon. Tijdens de serie experimenten waarbij de toevoer van bloed naar de tenuissimusspier werd verminderd door middell van verlaging van de bloeddruk, bleken naast een vergroting van de gemiddelde diameter van de arteriolen ook veranderingen in het vasomotionpatroon op te treden: zowel de amplitude als de cycluslengte werd groter in alle arteriolen (hoofdstuk 6). Daalde de bloeddruk een beetje, dan namen beide vasomotion parameters een beetje toe; daalde de bloeddruk sterk, dan namen de parameters ook sterk toe. In de eerste orde zijvaten bleek de verlenging van de vasomotioncyclus vooral veroorzaakt door een verlenging van de tijd van maximale opening (zie figuur 11.7). In deze figuur is duiclelijk te zien dat tijdens een sterke daling van de bloeddruk de vaten veel langer open blijven staan vergeleken met de controlesituatie (= normale bloeddruk). Er ontstaat als het ware een plateau in de maximaal geopende fase. Deze veranderingen zijn in overeenstem-

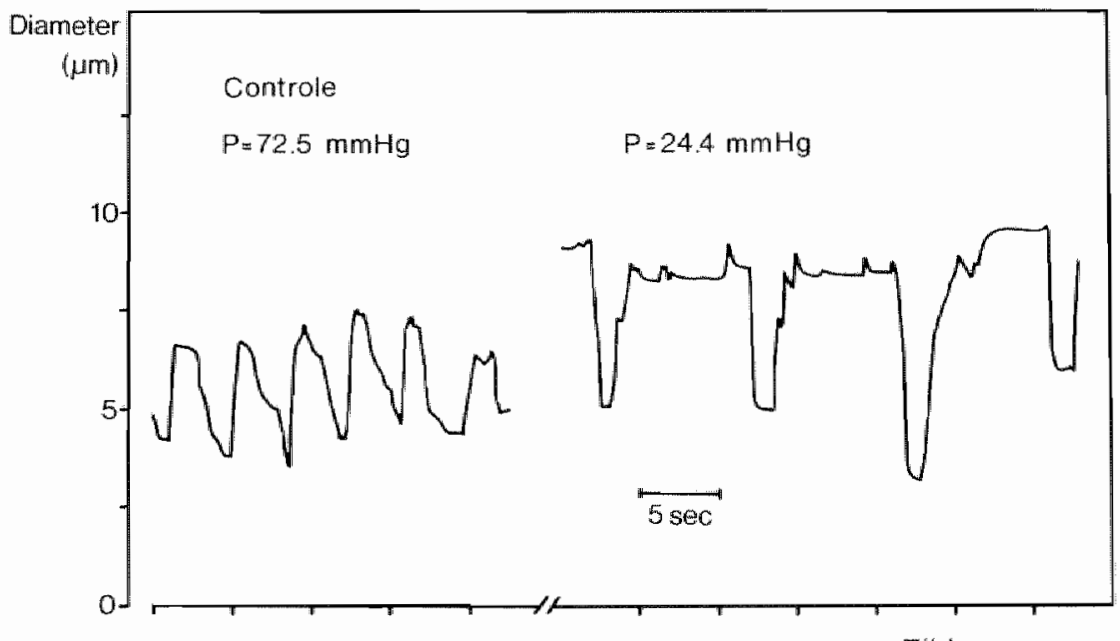

Thijd

FIGUUR 11.7: Vasomotionpatronem in een eerste orde zijwat tijdens controlesituatie (Vinks) en tijdens sterk verlaagde bloeddruk (rechts). $P=$ bloeddruk. 
ming met de gedachte dat de eerste orde zijvaten de fijnregeling van de bloedstroom naar de capillairen verzorgen. Tijdens bloeddrukverlaging zal er minder bloed naar de tenuissimusspier aangevoerd worden. De arteriolen reageren hierop met een toename van hun gemiddelde diameter, om zo toch voldoende bloed naar de capillairen te laten stromen. Dit is eerder al aangeduid met 'autoregulatie'. Daarnaast zorgt de aanwezigheid van vasomotion voor een zo homogeen mogelijke verdeling van het bloed over de capillairen. Een konsekwentie van vasomotion is dat de arteriolen gedurende een deel van de tijd (nagenoeg) gesloten zijn, waardoor de bloedstroom vermindert. Het lijkt erop dat ter kompensatie van deze gesloten fase de arteriolen tijdens de bloeddrukverlaging wat langer open blijven en zo toch voor een voldoende aanvoer van bloed zorgen.

Welke faktoren precies verantwoordelijk zijn voor de verandering van het vasomotion. patroon tijdens bloeddrukdaling is niet duidelijk. Diverse parameters zoals bloedstroom, bloeddruk en effectieve diameter bleken samen te hangen met de vasomotion veranderingen, maar geen van deze relaties bleek zeer sterk.

Een parameter die in de literatuur wordt aangevoerd om veranderingen in het vasomotion patroon te kunnen verklaren is rek van de vaatwand. In onze experimenten kan de rek het beste benaderd worden met de maximale diameter tijdens vasomotion (Dmax, zie figuur 11.3). Tijdens bloeddrukverlaging nam de rek van de vaatwand toe, terwijl ook de vasomotion cycluslengte en amplitude toenamen. In een andere serie experimenten waarbij de vaatverwijder adenosine werd gebruikt (hoofdstuk 7), nam de rek ook toe maar werden geen trendmatige veranderingen in cycluslengte of amplitude waargenomen. Uit de kombinatie van deze twee soorten experimenten mogen we konkluderen dat rek van de vaatwand geen rol speelt bij de hier beschreven veranderingen in het vasomotionpatroon.

Zoals boven al genoemd werden de veranderingen in het wasomotionpatroon van de eerste orde zijvaten tijdens bloeddrukdaling vooral veroorzaakt doordat het vat een langere tijd in de maximaal geopende fase verbleef. Kijkt u nogmaals in figuur 11.7 naar het ontstaan van de plateau's. Dit principe ging steeds op, zowel voor de kleine veranderingen in cycluslengte tijdens relatief kleine bloeddrukdalingen als voor de grote cycluslengteveranderingen tijdens de sterke bloeddrukdalingen. In de transverse arteriolen bleek dit principe ook op te gaan, echter alleen bij de sterke veranderingen in cycluslengte tijdens sterke bloeddrukdalingen. We vonden dat, zowel in de rustsituatie (figuur 1.8, situatie 1) als tijdens sterke dalingen van de bloeddruk (figuur 11.8, situatie 3), het vasomotionpatroon in de transverse arteriolen en hun eerste orde zijvaten precies synchroon loopt. Dit gold echter niet in de situaties waarbij de veranderingen in de cycluslengte maar klein waren, zoals door een beperkte bloeddrukdaling of door gebruik van adenosine. In die gevallen bleek het begin van vernauwing van het vat in de transverse arteriolen steeds iets eerder op te treden dan in de eerste orde zijvaten. Het begin van verwijding bij iedere vasomotioncyclus viel wel samen (zie figuur 11.8, situatie 2). 


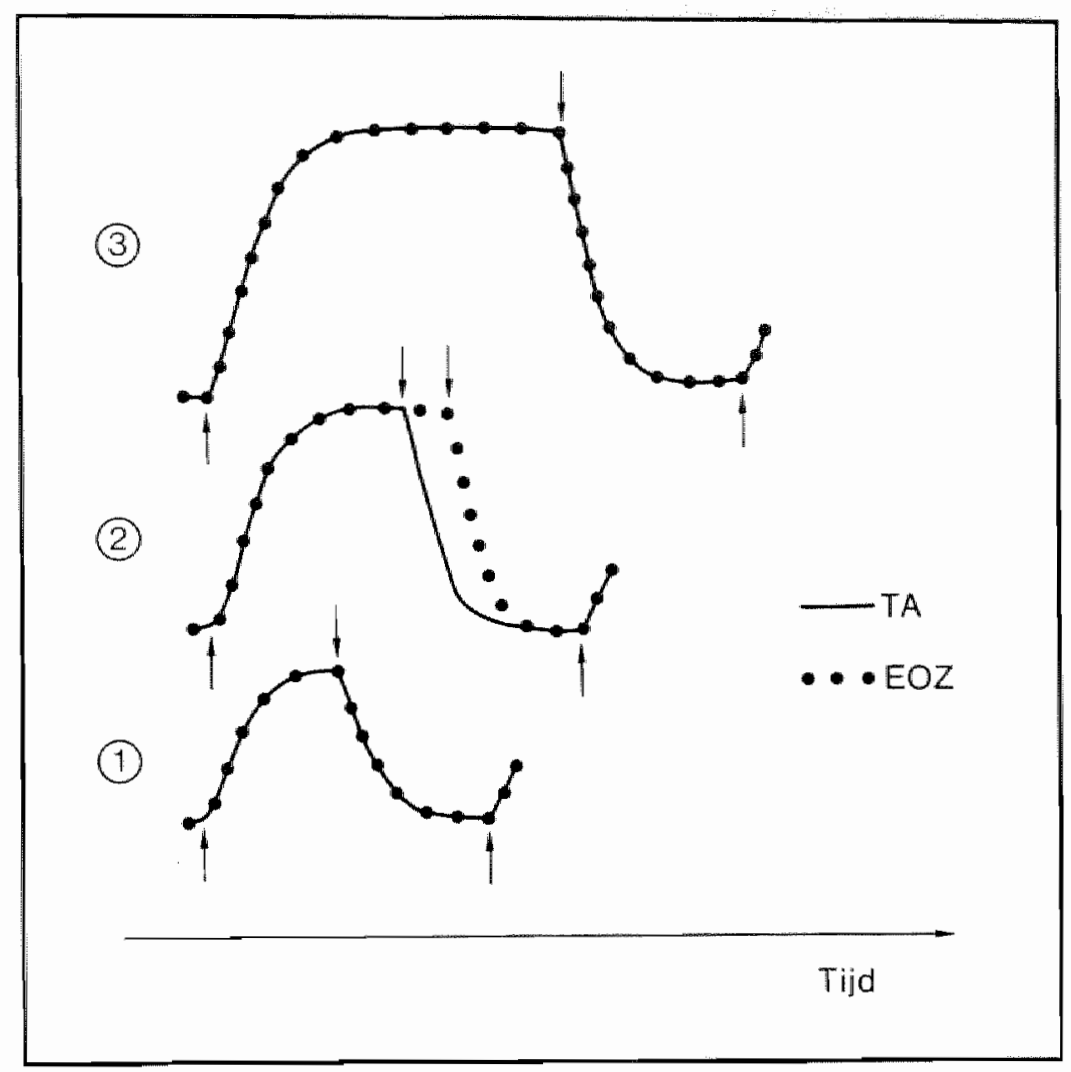

FIGUUR 11.8: Schematische samenvatting van de veranderingert in het wasomotionpatroon in transwerse ar. teriolen (TA) en eerste arde zijvaten (EOZ). 1 = controlesituatie; 2 = beperkte verandering in cyclustengte door adenosine of beperkte bloeddnikdaling; $3=$ sterke werandering in cycluslengte door sterke bloeddrukdaling. De pijlen geven het begin van verwijding en vernawwing aan.

Deze vinding leidt tot het verwerpen van de bestaande hypothese ontrent het ontstatan van vasomotion. De gedachte hierbij is dat in cen vaatbed bepaalde cellen in de vaatwand een elektrisch signaal uitzenden dat zich razendsnel over de arteriolen voortplant, waarna de gehele arteriole gaat samentrekken. Dit is eenzelfde principe als in het hart waar, na een signaal van enkele 'pacemaker'-cellen, alle hartspiercellen samentrekken. Als in het vaatbed van de tenuissimusspier een dergelijke klassieke 'pacemaker' aanwezig zou zijn, dan zouden de transwerse arteriolen en hun eerste orde zijvaten altijd vrijwel gelijktijdig moeten samentrekken ( = een gelijktijdig begin van de vernauwing van de diameter). Dit werd tijdens dit onderzoek niet steeds gevonden. Daarentegen bleek het begin van de verwijding wel steeds gelijktijdig. 
Omdat het begin van verwijding in de transwerse arteriolen en hun eerste orde zijvaten steeds samenvalt, maar het begin van vernauwing niet, lijkt vasomotion eerder een serie ritmische verwijdingen dan ritmische vernauwingen. Dit kan duiden op de aanwezigheid van een alternatief soort 'pacemaker', die niet het samentrekken maar wel het verwijden synchroniseert. Deze interessante bevinding verdient meer onderzoek, omdat over een dergelijk soort pacemaker nog niets bekend is. 



\section{CURRICULUM VITAE}

1958

1971-1977

$1977-1983$

1984-1988

1988- geboren te Almelo

V.W.O., Pius X College, Almelo

studie Biologie (cel-nivo), Landbouwhogeschool, Wageningen wetenschappelijk assistent, vakgroep Fysiologie, Rijksuniversiteit Limburg, Maastricht wetenschappelijk medewerker, afdeling Arbeidskunde, IMAG, Wageningen 


\section{PUBLICATIES}

Oude Vrielink, H.H.E., R.S. Reneman, D.W. Slaaf, and G.J. Tangelder. Vasomotion and reduced perfusion pressure in rabbit tenuissimus muscle. J. Physiol. (London) 366, 125P, 1985.

Oude Vrielink, H.H.E., D.W. Slaaf, G.J. Tangelder, and R.S. Reneman. Does capillary recrnitment exist in young rabbit skeletal muscle? Int. J. Microcirc.: Clin. Exp. 5, M81, 1986.

Oude Vrielink, H.H.E, D.W. Slaaf, G.J. Tangelder, and R.S. Reneman. Capillary recruitment does not occur in young rabbit tenuissimus muscle. Experientia 42, 1306, 1986.

Oude Vrielink, H.H.E., D.W. Slaaf, G.J. Tangelder, and R.S. Reneman. Does capillary recruitment exist in young rabbit skeletal muscle? Int. J. Microcirc.: Clin. Exp. 6, 321-332, 1987.

Oude Vrielink, H.H.E., D.W. Slaaf, G.J. Tangelder, and R.S. Reneman. Vasomotion in rabbit skeletal muscle during reduced perfusion pressure. Fed. Proc. 46, 1544, 1987.

Oude Vrielink, H.H.E., D.W. Slaaf, G.J. Tangelder, and R.S. Reneman. Vasomotion during reduction of arterial pressure in rabbit skeletal muscle. Pfiug. Arch. 410, \$31, 1987.

Oude Vrielink, H.H.E., D.W. Slaaf, G.J. Tangelder, and R.S. Reneman. Vasomotion waveform changes during dilatation of arterioles of rabbit terwissimus muscle. The FASEB Journal 2, M117, 1988.

Oude Vrielink, H.H.E., D.W. Slaaf, G.J. Tangelder, and R.S. Reneman. Origin of vasomotion cycle length changes during different interventions.. Int. J. Microcirc.: Clin. Exp. 7, \$150, 1988.

Oude Vrielink, H.H.E., D.W. Slaaf, G.J. Tangelder, and R.S. Reneman. Changes in wisomotion pattern du. ring different vasodilation stimuli. Int. J. Microcirc.: Clin. Exp. 7, S217, 1988.

Oude Vrielink,H.H.E., D.W. Slaaf, G.J. Tangelder, and R.S. Reneman. Changes in wasomotion pattern and local arteriolar resistance during stepwise pressure reduction. 1988, submitted.

Oude Vrielink, H.H.E., D.W. Slaaf, G.J. Tangelder, S. Weijmer-Van Velzen, and R.S. Reneman. Analysis of wasomotion waveform changes during pressure reduction and adenosine application. 1988, submitted. 


\section{NAWOORD}

$\mathrm{Nu}$ dit boekwerkje voltooid is moet ik onwillekeurig denken aan de Veluweloop. Bij deze estafetteloop snellen 16 mannen en vrouwen voort, ieder naar hun eigen vermogen, voor een zo goed mogelijk eindresultaat van hun team. Zo'n team van mensen staat ook achter dit proefschrift. Elk had een bijdrage zonder welke de eindstreep niet gehaald was. Ik ben iedere teamgenoot even dankbaar. Voor jullie bijdrage zeg ik mijn

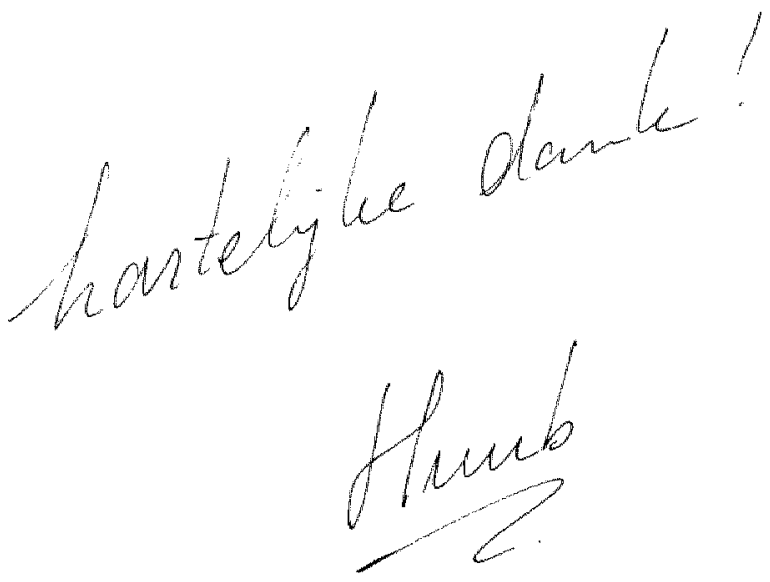

